RENATO SEDANO ONOFRI

\title{
A TEORIA DA CAUSA SUBJETIVA COMO EXPRESSÃO JUSRACIONALISTA NO Código COMERCIAL BRASILEIRO DE 1850
}

Dissertação de mestrado realizada sob orientação do Professor Titular IGNACIO MARIA POVEDA

VELASCO, no Departamento de Direito Civil - Área de História do Direito da Faculdade de Direito da Universidade de São Paulo.

São Paulo

Janeiro de 2012 
Para Valéria, Luiz, Mariana e Henrique, as verdadeiras Luzes em minha vida. 


\section{$\underline{\text { ÍNDICE }}$}

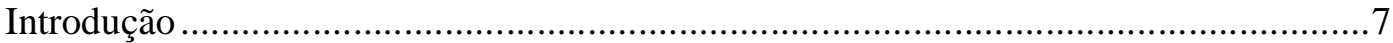

$\S 1^{\circ}$ - Breve apresentação. …........................................................................

$\$ 2^{\circ}$ - Inovação e reforma promovidos pelo jusracionalismo do século XVIII......8

$\S 3^{\circ}$ - O movimento codificador como corolário do jusracionalismo do séc. XVIII9

$\$ 4^{\circ}$ - Iluminismo e reforma em Portugal.

$\S 5^{\circ}$ - Situação geral da historiografia jurídica brasileira quanto ao impacto de ideias jusracionalistas em nosso ordenamento

$\S 6^{\circ}$ - Relativização das posições expostas quanto ao Direito Comercial brasileiro Direito Comercial brasileir 12

$\$ 7^{\circ}$ - Indícios da penetração de inovações jusracionalistas no Direito Comercial brasileiro 14

$\S 8^{\circ}$ - Possível resultado da influência jusracionalista no Código Comercial

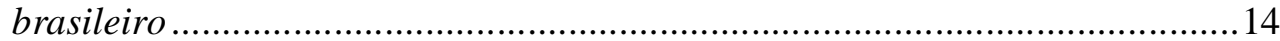

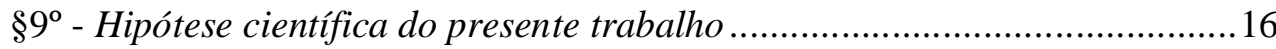

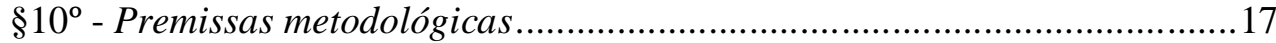

$\$ 11^{\circ}$ - Plano de trabalho ............................................................................21

Capítulo 1 - O Iluminismo jurídico em Portugal e suas consequências em relação à metodologia de integração de lacunas no Direito luso-brasileiro. ................................22

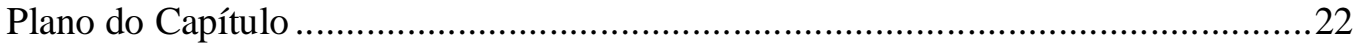

1.1 - A introdução das ideias iluministas em Portugal: Luís ANTÓNIO VERNEY e o Verdadeiro Método de Estudar. 22

1.1.1 - VERNEY, a publicação do Verdadeiro Método de Estudar e as "cartas a

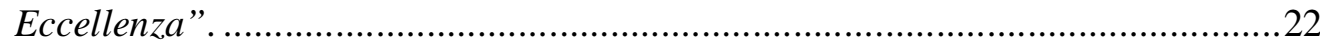

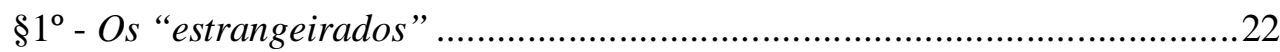

$\$ 2^{\circ}$ - O Verdadeiro Método de Estudar. ........................................................22

$\$ 3^{\circ}$ - As cartas e relatórios a "Eccellenza”, de 1765-1766................................24

1.1.2 - Os principais aspectos ligados à ciência jurídica contidos no Verdadeiro

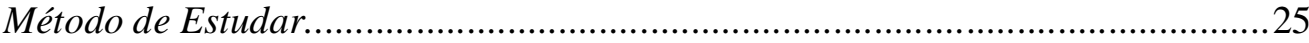

$\S 1^{\circ}$ - Críticas ao ensino jurídico em Portugal................................................25

$\$ 2^{\circ}$ - Propostas de alterações no ensino jurídico...........................................2 27

1.1.3 - Cartas e relatórios dirigidos por LUÍS ANTÓNIO VERNEY a "Eccellenza”. ..29

$\S 1^{\circ}$ - O papel de Verney nas reformas pombalinas. ........................................29

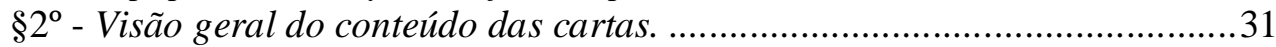

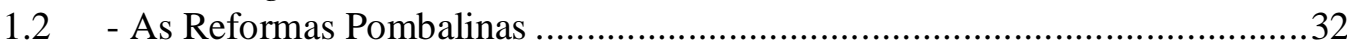

1.2.1 - Breve aceno sobre o sistema de integração de lacunas anterior à reforma

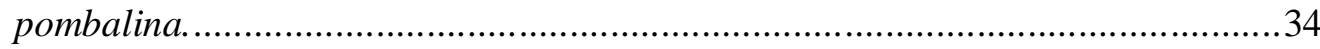

$\S 1^{\circ}$ - O sistema inaugurado pelas Ordenações Afonsinas ................................34

$\S 2^{\circ}$ - As modificações insertas pelas Ordenações Manuelinas em sua versão primitiva, pelas Ordenações Manuelinas de 1521 e o regramento do direito subsidiário nas Ordenações Filipinas. 36 $\S 3^{\circ}$ - Distorções na aplicação das fontes subsidiárias e a necessidade de reforma.

1.2.2 - As reformas pombalinas no sistema de fontes subsidiárias e no ensino jurídico: a introdução do usus modernus pandectarum em Portugal. 42

$\S 1^{\circ}$ - A Lei da Boa Razão, os Estatutos da Universidade de 1772 e o novo sistema de fontes subsidiárias. 
$\S 2^{\circ}$ - Posteriores desenvolvimentos empreendidos pelo individualismo crítico em

Portugal.

$\$ 3^{\circ}$ - Consequências da nova metodologia de integração de lacunas no direito

privado português e brasileiro.

Capítulo 2 - Os primeiros passos do Direito Comercial brasileiro: a abertura dos portos, a ascensão de uma nova elite e a aplicação da legislação estrangeira no Brasil. ...............53

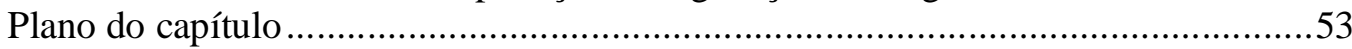

2.1 - A abertura dos portos e sua influência no direito comercial brasileiro .................54

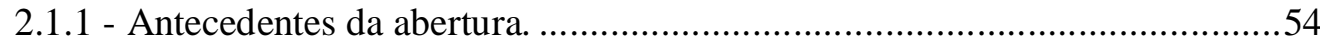

$\S 1^{\circ}$ - Portugal e Brasil entre Inglaterra e França.............................................54

$\$ 2^{\circ}$ - O conflito franco-britânico .................................................................54

$\S 3^{\circ}$ - A Convenção Secreta de Londres (22 de outubro de 1807) ......................57

$\$ 4^{\circ}$ - Interesses ingleses por trás da Convenção Secreta ..................................59

$\S 5^{\circ}$ - Fechamento dos portos portugueses à navegação inglesa .........................60

$\S 6^{\circ}$ - Reação inglesa ao fechamento e providências para transferência da corte61

2.1.2. A chegada da Família Real e a abertura dos portos...................................63

$\S 1^{\circ}$ - O desembarque e as primeiras medidas em território brasileiro ...............63

$\S 2^{\circ}$ - A carta régia de 28 de janeiro de 1808 e a abertura dos portos brasileiros às

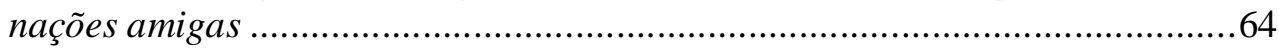

$\$ 3^{\circ}$ - O caráter da abertura dos portos...............................................................66

$\$ 4^{\circ}$ - A concorrência de José da Silva Lisboa para o caráter da abertura dos portos

5 $5^{\circ}$ - As nações amigas de Portugal

$\$ 5^{\circ}$ - As naçóes amigas de Portugal ............................................................69

$\$ 6^{\circ}$ - Uma pré-abertura dos portos? A tese de José Jobson de Andrade Arruda 71

2.1.3 - Consequências da abertura dos portos: a ascensão de uma nova elite, um

"novo" aparato burocrático e utilização da legislação estrangeira para integração de

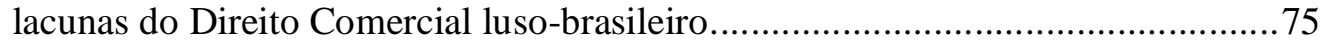

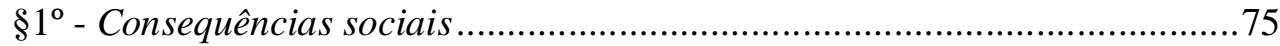

$\S 2^{\circ}$ - Consequências no âmbito administrativo da colônia .............................77

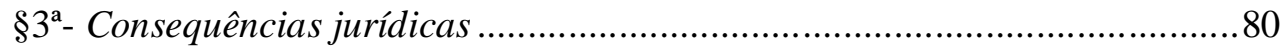

$\S 4^{\circ}$ - Impacto na codificação do Direito Comercial brasileiro...........................85

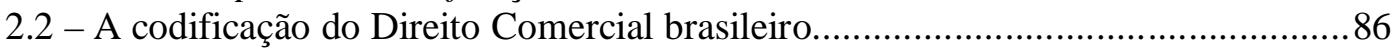

2.2.1 - A primeira tentativa: José da Silva Lisboa...............................................86

$\S 1^{\circ}$ - A consulta a Real Junta e a escolha de Cairu para elaboração de um projeto

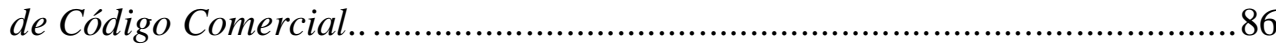

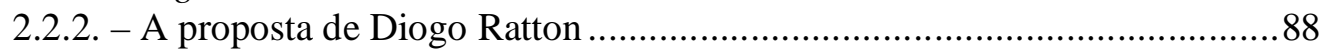

$\S 1^{\mathrm{o}}$ - A proposta de adoção do Código Comercial francês. .................................88

$\S 2^{\circ}$ - A reação do Visconde de Cairu .............................................................8 89

2.2.3 - A segunda tentativa: o projeto da Comissão extraparlamentar da Regência.90

$\S 1^{\circ}$ - Nomeação da Comissão extraparlamentar. ............................................99

$\S 2^{\circ}$ - O projeto de Código Comercial .............................................................90

$\S 3^{\circ}$ - O trâmite legislativo do projeto ...........................................................92

Capítulo 3 - A teoria da causa subjetiva no âmbito do tratamento legislativo dispensado aos contratos mercantis pelo Código Comercial brasileiro. ............................................ 95

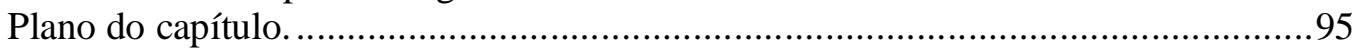

3.1 - Breve nota a respeito das fontes justinianéias e do pensamento medieval em torno do

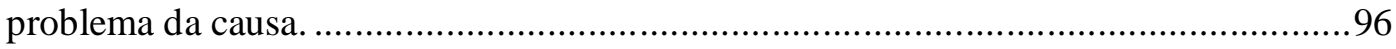

3.1.1 - Alguns significados do termo causa nas fontes justinianéias. ....................96

$\$ 1^{\circ}$ - Emprego do termo em sentidos diversos a consequente falta de teorização $e$ sistematicidade da teoria da causa no Direito Romano....................................96 
3.1.2 - A causa no direito medieval. ................................................................ 98

$\S 1^{\mathrm{a}}$ - A causa no pensamento escolástico......................................................98

3.3 - A elaboração da teoria da causa no período Iluminista ................................100

3.3.1 - As obras de DoMAT e POTHIER e a adoção de sua doutrina pelo Code Civil.100

$\S 1^{\circ}$ - O papel de Jean Domat ........................................................................... 101

$\$ 2^{\circ}$ - O desenvolvimento de Robert Joseph Pothier ....................................... 101

$\S 3^{\circ}-$ A adoção da teoria pelo Code Civil ...................................................... 101

$\S 4^{\circ}$ - Esclarecimento terminológico: causa enquanto requisito do contrato e causa

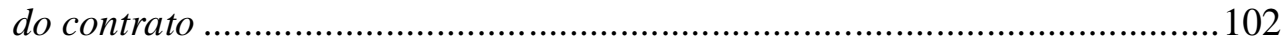

$\S 5^{\circ}$ - Principais características da teoria subjetiva da causa.......................... 102

3.4 - O tratamento dispensado à causa pelo Direito Comercial brasileiro ................ 104

3.4.1 - A causa na doutrina comercialista dos principais autores em língua portuguesa.

.

$\S 1^{\circ}$ - O Dicionário Jurídico-Comercial de José Ferreira Borges..................... 104

$\S 2^{\circ}$ - O tratado quinto dos Princípios de Direito Mercantil de José da Silva Lisboa

3.4.2 - A causa no Código Comercial de 1850 ….................................................... 107

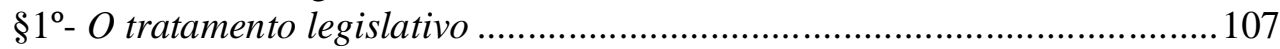

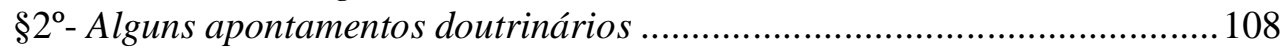

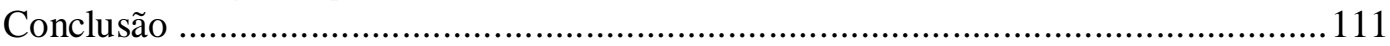

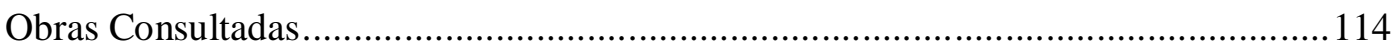

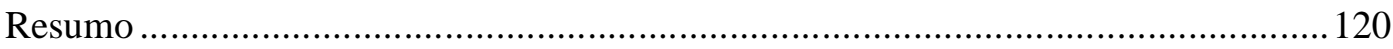

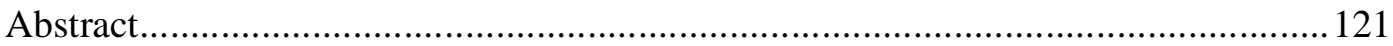




\section{$\underline{\text { Agradecimentos }}$}

Ainda que apenas um nome apareça na capa do trabalho, não há obra que se faça sozinho. Pude contar, ao longo dos meus três anos no Programa de Pós-Graduação da Faculdade de Direito da Universidade de São Paulo, com o apoio, cooperação e paciência de muitos amigos.

A começar por meu orientador, Professor Titular Ignacio Maria Poveda Velasco, a quem agradeço não apenas pela oportunidade de ingresso no mestrado, mas também - e talvez principalmente - por ter me aceitado como monitor da cadeira de História do Direito no ano de 2006, fato que - não é exagero dizer - foi fundamental em minha vida.

Agradeço ao Professor Doutor Estevan Lo Ré Pousada pela amizade e conhecimento compartilhado ao longo dos anos. Agradeço também pelas valiosas contribuições feitas ao trabalho na banca de qualificação.

Ao Professor Eduardo Doutor Tomasevicius Filho pelas contribuições na banca de qualificação e pela convivência como integrante do corpo docente das Faculdades Integradas Campos Salles.

A todos os integrantes do Grupo de Pesquisa e Monitoria da Faculdade de Direito da Universidade de São Paulo, a quem agradeço no nome da Professora Maria Cristina S. Carmignanni.

Devo agradecer aos amigos de outrora: Arnaldo, Josiane, Naldo e Viviane; e também aos amigos de outrora e sempre: Paulo Henrique Signori Pinese, Paulo Cesar Cardozo da Silva Filho, Tiago Zanella, Juliana Miashiro, Renato P. Leon, Rafael T. Bassoli, Plinio Pontes Rodrigues e Jadiel William Tiago.

Por fim, agradeço especialmente - além das quatro pessoas a quem este trabalho é dedicado -, aos amigos Ricardo Monier, Rodrigo Sérgio Meirelles Marchini, Maria Claudia Pardo Tenório e Tabir Dal Poggetto O. Sueyoshi, cujas constantes companhias e apoio foram fundamentais para que pudesse dar um ponto final a neste trabalho. 


\section{Introducão}

$\$^{\circ}$ - Breve apresentação. Ao longo do ano de 2011, o Direito Comercial e, mais especificamente, a codificação do Direito Comercial - esteve em evidência no meio acadêmico, principalmente por conta do projeto de Código Comercial inserto pelo Professor FÁBio UlHOA COELHO em sua obra $O$ futuro do direito comercial ${ }^{1}$, que resultou no Projeto de Lei no 1572 /11, proposto pelo Deputado Vicente Cândido.

O projeto, ora submetido à consulta pública ${ }^{2}$, reacendeu o debate sobre autonomia do Direito Comercial em relação ao Direito Civil, e sobre a necessidade de reafirmação dos princípios que o singularizam enquanto subramo do Direito Privado.

Com efeito, FÁbio UlhoA CoElho afirma que "os valores do direito comercial estão esgarçados", de modo que há necessidade de "recosê-los", tornando o regramento das relações comerciais mais compreensível e aplicável no contexto social contemporâneo. A vigência de um novo Código Comercial, na opinião do ilustre Professor, exerceria importante papel neste sentido, pois "serviria para criar não somente um significativo momento de profunda reflexão da comunidade jurídica sobre os valores nele encetados, como também proporcionaria a renovação da produção doutrinária e jurisprudencial, com a superação de muitos conceitos velhos e anacrônicos e arejamento dos que ainda têm operacionalidade"

Dado, portanto, este momento de retomada de reflexões a respeito do Direito Comercial e sua codificação, parece ser oportuna a apresentação de um trabalho que trate, justamente, da Codificação do Direito Comercial a partir de um ponto de vista histórico.

\footnotetext{
${ }^{1}$ CoElho, Fábio Ulhoa. O futuro do direito comercial, São Paulo, Saraiva, 2011.

${ }^{2}$ Estágio da proposta conferido até o dia 20 de dezembro de 2011.

${ }^{3}$ CoElho, Fábio Ulhoa, op. cit. (nota 1), págs. 7-8. Em debate realizado no Salão Nobre da Faculdade de Direito do Largo São Francisco, aos 31 de agosto de 2011, o Professor Doutor José AlEXANDRE TAVARES GUERREIRO, em resposta ao autor do projeto, afirmou que os Códigos Comerciais, ao longo da história, nunca alcançaram o prestígio dos Códigos Civis, e que mesmo o Código Comercial de 1850 foi, de pouco em pouco, "esvaziado", o que revela a tendência de pulverização pelo ordenamento do regramento comercial. Esse dado revelaria, por sua vez, a pouca afeição deste ramo do Direito Privado à codificação. Deste modo, o Professor TAVARES GUERREIRO afirma temer que o novo Código seja, antes de tudo, irrelevante.
} 
A escolha do tema, no entanto, não está diretamente relacionada com o momento mencionado, mas com o contato, desde os tempos de graduação, com a temática da Codificação do Direito Privado no Brasil, suas peculiaridades e vicissitudes.

A presente dissertação guarda profundo paralelismo - inclusive em sua estrutura - com o trabalho apresentado pelo Professor ESTEVAN Lo RÉ POUSADA, no ano de $2006^{4}$, sob orientação do Professor Titular IGNÁCIO MARIA PovedA VElasCo, que tratava da preservação da tradição jurídica luso-brasileira no Brasil. Nossas pesquisas seguiram o caminho oposto, procurando identificar não a preservação de uma tradição jurídica, mas, pelo menos, um ponto de sua relativização no ordenamento brasileiro. É o que passamos a expor.

\section{$\$ 2^{\circ}$ - Inovação e reforma promovidos pelo jusracionalismo do século}

XVIII. "Dimidium facti, qui coepit, habet: sapere aude, incipe..." . O dito horaciano serviu de mote aos pensadores de toda a Europa que, ao longo dos séculos XVII e XVIII, promoveram reformas nas mais diversas áreas do conhecimento humano, visando à superação do modo de vida do "Antigo Regime".

O direito não passou incólume pelo período ${ }^{6}$. Aproveitando-se da metodologia das ciências "matemáticas", os juristas pretenderam elaborar um novo sistema jurídico, abandonando a tradição do Direito Comum. O novo sistema teria como fundamento único a razão, que, a partir da observação da natureza humana, elaboraria preceitos com validade universal, a exemplo dos enunciados das ciências exatas.

Seguindo essa orientação metodológica, formou-se, na era moderna, uma nova concepção do direito natural. Como era tradicional, havia a referência à natureza do homem e da sociedade, mas na síntese de RAOUl CHARLES VAN CAENEGEM, em primeiro lugar, o sistema de direito natural da Era Moderna recusava-se a derivar seus preceitos de

\footnotetext{
${ }^{4}$ Pousada, Estevan Lo Ré. Preservação da tradição jurídica luso-brasileira: Teixeira de Freitas e a introdução à Consolidação das Leis Civis, Dissertação, São Paulo, 2006.

${ }^{5}$ Em tradução livre: "Metade da obra tem aquele que começa: ousa saber, começa..." (HorÁcIO. Epistolas, livro I, ep. II Ad Lollium). Sobre as diversas interpretações que se fez do mote iluminista, veja-se VENTURI, Franco. Utopia and reform in the Enlightenment, Cambridge, Cambridge University Press, 1971 (trad. port. FlORENZANO, Modesto, Utopia e reforma no iluminismo, Bauro, Edusc, 2003), págs. 33-39.

${ }^{6}$ FrANZ WIEACKER aduz que as ideias iluministas concernentes à ciência jurídica foram "a força mais poderosa no desenvolvimento do moderno direito depois do Corpus Iuris (...)". (Privatrechtgechichte der neuzeit unter besonder Berücksichtigungder deutschen Entwicklung, $2^{\mathrm{a}}$ ed., Göttingen, Vandenhoeck und Ruprecht, 1967 (trad. port. HesPANHA, Antônio Manoel Botelho. História do direito privado moderno, $2^{\mathrm{a}}$ ed., Lisboa, Calouste Gulbenkian, 1993), pág. 297.
} 
sistemas externos, como o direito divino ou o Corpus Iuris Ciuilis. Procuravam-se princípios evidentes e axiomáticos, por meio do estudo racional e da crítica da natureza humana, de que se pudessem deduzir morer geometrico (ou seja, pela aplicação de métodos matemáticos) todos os preceitos. Daí R.C. VAN CAENEGEM afirmar que "o nome 'direito da razão' (Vernunftrecht) é, portanto, mais adequado do que 'direito natural', que possui outras conotações ${ }^{7} "$.

Assim, o direito natural não era visto como um ideal de justiça com uma significação maior do que a ordem jurídica positiva. Bem ao contrário, o direito natural era tido como "um corpo de princípios" de que deveria ser diretamente derivado o direito positivo. Era, portanto, um "direito natural aplicado".

\section{$\S^{\circ}$ - O movimento codificador como corolário do jusracionalismo do séc.}

XVIII. A legislação, de um modo geral, e os códigos, especialmente, foram responsáveis pela introdução das reformas jusracionalistas nos ordenamentos nacionais.

Ainda de acordo com R.C. vAN CAENEGEM, a legislação assumiu papel relevante - quase que exclusivo em alguns países, como a França -, na tarefa de conduzir as novas ideias para o plano prático, uma vez que as decisões dos tribunais e as universidades tiveram participação muito tímida neste sentido ${ }^{9}$.

Leis e códigos foram, portanto, os elementos de ligação entre a dimensão intelectual do Iluminismo e a dimensão pragmática reformadora. Desse modo, muitas das construções intelectuais elaboradas no âmbito jurídico ao longo dos séculos XVII e XVIII ganharam vida e aplicabilidade nos códigos.

\footnotetext{
${ }^{7}$ CAENEGEM, Raoul Charles van. Introduction historique au droit prive, Bruxelles, Story-Scentia, 1988 (trad. port. Carlos Eduardo Lima Machado. Uma introdução histórica ao direito privado, $2^{\mathrm{a}}$ ed., São Paulo, Martins Fontes, 2000), págs. 164-165.

${ }^{8}$ Idem, Ibidem, pág. 165. Em relação a este aspecto - "direito natural aplicado" -, é interessante ver que, ainda em 1861, Delam ARRE e LE POITVIN abriam seu tratado de Direito Comercial atestando a existência do direito natural e afirmando serem o Código Civil e o Código Comercial a aplicação deste direito natural a duas ordens definidas de coisas: "Il existe un droit naturel; le Code civil et le Code de commerce sont deux applications de ce droit à deux ordres définis de choses (...)" (Traité théorique et pratique de droit commercial, tomo I, $2^{a}$ ed., Paris, Chales Hingray, 1861, pág. 1).

9 Idem, Ibidem, pág. 170. Veremos abaixo, no capítulo 1, que se na França as Universidades e a Jurisprudência tiveram papel tímido na colocação em prática do programa Iluminista, em Portugal, bem ao contrário, foram as duas principais janelas de abertura para as inovações no âmbito jurídico.
} 
$\$ 4^{0}$ - Iluminismo e reforma em Portugal. O Iluminismo - com sua vertente jurídica, o jusracionalismo - alastrou-se, geograficamente, pela Europa de modo geral, mas de maneira não uniforme quanto às suas características.

Se, na França, culminou com a Revolução, em Portugal, culminou com uma série de reformas conduzidas não por um movimento revolucionário, mas pela própria Coroa.

A introdução das ideias Iluministas em Portugal deu-se pela atuação dos chamados "estrangeirados", em especial Luís António Verney, que, por meio de sua obra "Verdadeiro Método de Estudar" influenciou as reformas empreendidas pelo Marquês de Pombal, na segunda metade do século XVIII ${ }^{10}$.

As reformas, por sua vez, foram empreendidas em três frentes: a legislação, a jurisprudência e o ensino. Dois atos legislativos pombalinos foram fundamentais para a história do direito português e brasileiro: foram eles a Lei de 18 de agosto de 1769 (Lei da Boa Razão), e os Novos Estatutos da Universidade de Coimbra, de 1772; a primeira, reformando a jurisprudência e o sistema de direito subsidiário das Ordenações do Reino; a segunda, reformando o ensino universitário ${ }^{11}$.

Tais diplomas formaram um programa reformador bem estruturado sobre os ideias Iluministas, promovendo, em certa medida, o abandono de algumas tradições jurídicas muito antigas ${ }^{12}$.

\footnotetext{
${ }^{10}$ A respeito do papel do VERNEY na introdução das ideias Iluministas em Portugal, ver, adiante, o capítulo 1. ${ }^{11}$ A Lei de 18 de agosto de 1769 teve impacto decisivo na evolução do direito português e brasileiro. Por meio dela, a administração pombalina reformou por completo o sistema de direito subsidiário, mitigando a importância do direito romano, excluindo por completo o direito canônico, as glosas de Acúrsio e os comentários de Bártolo, aos quais se atribuía a responsabilidade pela insegurança que se instalara na doutrina e jurisprudência. Nas palavras de NuNO J. EsPinOSA GOMES DA Silva, "nas Ordenações Filipinas pode dizer-se que, como fontes de direito, se indicavam grosso modo, a vontade do rei e o utrumque ius. Agora, no século das luzes, mantém-se a vontade do monarca, mas pretende-se substituir o utrumque ius pela razão". (História do direito português: fontes de direito, $4^{\mathrm{a}}$ ed., Lisboa, Calouste Gulbenkian, 2006, pág. 464).

Ao mesmo tempo, a Lei da Boa Razão estabeleceu novas orientações para a jurisprudência, na medida em que modificou as regras para a tomada de assentos, concentrando, com isso, maior autoridade na Casa da Suplicação de Lisboa, em detrimento dos tribunais de Relações subalternos.

Por fim, a reforma dos Estatutos da Universidade teve por finalidade complementar o que havia sido iniciado com a Lei de 18 de agosto de 1769, visando educar os novos juristas sob os preceitos da nova mentalidade.

Veremos o processo reformador pombalino em detalhes no capítulo 1 do presente trabalho.

12 Estevan Lo Ré Pousada indica a reforma do direito das sucessões empreendida por Pombal, antes mesmo da Lei da Boa Razão, como exemplificativa de um aspecto do direito português, tomado do direito romano justinianeu, que foi modificado com base nas novas ideias. As Leis de 24 de junho de 1766 e de 09 de setembro de 1769 "apresentam sensível inspiração jusnaturalista, evidenciada na apologia da sucessão legítima (adequada aos ditames da razão natural) em detrimento da liberdade testamentária consagrada pela tradição lusitana desde o renascimento do direito justinianeu”. (Cit. (nota 4), págs. 68-69).
} 
$\$ 5^{\circ}$ - Situação geral da historiografia jurídica brasileira quanto ao impacto de ideias jusracionalistas em nosso ordenamento ${ }^{13}$. Durante todo o período em que foi colônia e parte do período imperial, o Brasil teve um ordenamento jurídico comum a Portugal. Todavia, este dado não representou impedimento para que, a partir da independência política do Brasil, os ordenamentos de ambas as nações tomassem rumos diversos, principalmente em relação ao Direito Privado.

Tradicionalmente, a historiografia jurídica, tanto no Brasil quanto em Portugal, noticia uma linha de continuidade entre a tradição luso-brasileira e o Direito Privado brasileiro, especialmente o direito civil, após a separação entre colônia e metrópole.

Deve-se compreender o sentido da aduzida continuidade nos seguintes termos: o Direito Privado brasileiro, ao contrário do português, teria escapado, de maneira geral, da influência do jusracionalismo e suas inovações que, pretensamente, rompiam com o Antigo Regime e o ius commune.

Com efeito, Portugal viu penetrar-lhe as ideias jusracionalistas por entre os imensos espaços deixados abertos em seu ordenamento jurídico pelas lacunas e remissões ao direito subsidiário das Ordenações Filipinas - espaços que a Lei de 18 de Agosto de 1769, a Lei da Boa Razão, e os Estatutos da Universidade de Coimbra de 1772 orientaram o preenchimento.

Em Portugal, o individualismo crítico da primeira metade do século XIX procurava na legislação, jurisprudência e doutrina estrangeiras o critério para aferição do usus modernus pandectarum, elevado, por sua vez, a fonte subsidiária pelos Estatutos de 1772. Neste período, incorporaram-se ao direito português, especialmente ao direito privado, muitas das inovações jusracionalistas que foram levadas à prática pela codificação francesa, especialmente pelo Code Civil de $1804^{14}$.

\footnotetext{
${ }^{13}$ Ao longo do trabalho, utilizaremos os termos história e historiografia no sentido da recomendação teórica sintetizada por JULIO ARÓSTEGUI. O autor procura explicitar a importância da utilização de palavras diferentes para indicar a investigação e escrita da história e a realidade histórica em si mesma. Apoiando-se em TOPOLSKY, ARÓSTEGUI defende que historiografia cumpre bem o papel de indicar a escrita da história sem gerar confusão com seu próprio objeto, a história - a realidade histórica. Cfr. ARÓsTEGUI, Júlio. La investigación histórica: teoria y método, Barcelona, Critica, 1995 (trad. port. Andréa Dore, A pesquisa histórica: teoria e método, Bauru, Edusc, 2006), págs. 23-37.

${ }^{14}$ Sobre este aspecto, veja-se, novamente, ESTEVAN Lo RÉ POUSADA: “com isso, promove-se uma reviravolta quanto à utilização do critério estabelecido pela Escola Jusnaturalista portuguesa, dando-se ao usus modernus a acepção de direito estrangeiro das nações civilizadas da Europa”. (Cit. (nota 4), pág. 90)
} 
No Brasil, por outro lado, a vigência das Ordenações Filipinas por mais de três séculos, possibilitada pela conjunção de diversos fatores, acarretou a preservação da tradição jurídica. Isto é, não se observou, entre nós, o efeito de rompimento que o jusracionalismo acarretou alhures ${ }^{15}$.

\section{$\$ 6^{\circ}$ - Relativização das posições expostas quanto ao Direito Comercial}

brasileiro. Se, no que se refere ao direito civil, a preservação da tradição é verdade difícil de ser refutada, o outro ramo do direito privado, o Direito Comercial, demonstra, principalmente por meio da obra codificadora - que teve início em 1832 e terminou em 1850, com a promulgação do Código Comercial - que o direito privado brasileiro não

${ }^{15}$ É neste sentido que se manifesta GUILHERME BRAGA DA CRUZ. De acordo com o historiador, aproveitaramse, em Portugal, as normas de integração de lacunas e de interpretação da época jusracionalista para que fossem introduzidas, pela via doutrinal, inovações de fundo individualista bebidas nos Códigos posteriores à Revolução Francesa (A formação histórica do moderno direito privado português e brasileiro, in Revista da Faculdade de Direito da Universidade de São Paulo, vol. 50, 1955, pág. 53). A ação criadora da doutrina teria atuado em três frentes: 1) a formulação de novas interpretações a respeito de textos legislativos que se mantinham em vigência; 2) a divulgação de novas doutrinas, contrárias ao Direito vigente, com a intenção de implantá-las em vista do desuso das velhas normas das Ordenações, ou defendendo as inovações de iure constituendo; e, por fim, 3) ação exercida nas lacunas em que as normas vigentes remetiam a solução para o direito subsidiário (Idem, Ibidem, pág. 57). Tal ação criadora terminou por ser cristalizada no Código Civil português de 1967.

No que se refere ao direito brasileiro, o historiador do direito português aduz que "a desorientação doutrinal e filosófica resultante da penetração das ideias liberais foi, no Brasil, acentuadamente menor que em Portugal" (Idem, Ibidem, pág. 65). Por essa razão, "o Código Civil Brasileiro constitui, em pleno século XX, uma expressão muito mais fiel da tradição jurídica portuguêsa do que o próprio Código Civil Português, promulgado 50 anos antes!" (Idem, Ibidem, pág. 69). As referências feitas por Braga da Cruz são, respectivamente, ao Código Civil brasileiro de 1916, e ao Código Civil português de 1867.

O apontado diagnóstico de uma maior preservação da tradição jurídica lusitana entre nós é feito, também, por autores brasileiros. Veja-se, por exemplo, José CARLOS MOREIRA Alves: "O direito civil brasileiro deita suas raízes no antigo direito civil português, ligando-se a este mais estreitamente do que o próprio direito civil lusitano dos tempos modernos" (Panorama do direito civil brasileiro: das origens aos dias atuais, in Revista da Faculdade de Direito da Universidade de São Paulo, vol. 88, 1993, pág. 186).

Também ORLANDo Gomes se manifesta da mesma forma. De acordo com esse autor, a longevidade das Ordenações Filipinas no Brasil singulariza a história do direito civil brasileiro, pois teria ela impedido que o país se integrasse no movimento de renovação legislativa que, a partir da França, tomou os países ocidentais no século XIX. (Raízes históricas e sociológicas do código civil brasileiro, $1^{\mathrm{a}}$ ed., São Paulo, Martins Fontes, 2003, pág. 3).

Corroborando o sentido da conservação no direito civil brasileiro, PONTES DE MIRANDA aponta que, mesmo quando se seguiu o Código Civil francês, não se deu propriamente qualquer inovação. Aduz o autor que, das 1929 fontes materiais do Código Civil brasileiro de 1916, a que mais concorreu quantitativamente foi o Code Civil, com 172, "menos por si do que pela expressão moderna que dera a regras romanas". Isto é, concorreu por oferecer novas expressões às regras antigas, e não pelas inovações nele contidas (Fontes e evolução do direito civil brasileiro, $2^{\text {a }}$ ed., São Paulo, RT, 1981, pág. 93).

No tocante ao papel conservador exercido pela obras de TEIXEIRA DE FREITAS, ver, por todos, ESTEVAN LO RÉ POUSADA: "Se por um lado a obra de A. TEIXEIRA DE FREITAS evidencia um caráter sensivelmente inovador - sobretudo através da estruturação particular conferida a seu sistema de exposição do direito privado - pode-se divisar na própria Introdução à Consolidação das Leis Civis uma forte tendência conservadora. Daí o título deste trabalho, tomando-se o autor não apenas como o mais inovador de todos os nossos juristas, mas como um dos principais elementos de preservação da tradição jurídica luso-brasileira" (PousADA, Estevan Lo Ré, op. cit. (nota 4), pág. 16). 
passou tão incólume quanto possa parecer à primeira vista em relação às inovações do jusracionalismo, efetivadas pelo movimento codificador do século XVIII e início do século XIX.

\section{O Direito Comercial brasileiro recebeu a influência jusracionalista}

indiretamente, por meio, principalmente, dos Códigos Comerciais da França (1807), da Espanha (1829) e de Portugal (1833) ${ }^{16}$.

A explicação para essa diferenciação entre os dois ramos do direito privado é encontrada na própria Lei de 18 de agosto de 1769, já que, em relação ao Direito Mercantil $^{17}$, a Lei da Boa Razão mandava aplicar, subsidiariamente, não o Direito Romano conforme à boa razão, mas o Direito das nações cristãs cultas e polidas da Europa ${ }^{18}$.

${ }^{16}$ É o próprio GuILHERME BRAGA DA CRUZ quem chama atenção para o fato de que, no Brasil, o "direito privado, em si mesmo, nem direta, nem indiretamente recebeu, por via legislativa, alterações de grande vulto, se excetuarmos a importante reforma do direito comercial, levada a cabo com a promulgação do Código de 1850" (Cit. Formação (nota 15), pág. 66). No mesmo sentido Clovis Veríssimo do CouTO e Silva: "Não é, entretanto, difícil estabelecer as razões pelas quais o Direito Civil brasileiro manteve-se imune às influência do Código Napoleônico, ao contrário do que sucedeu com o Código Comercial de 1850, que sofreu forte influência do Código Comercial francês de 1807”. (Couto E SILVA, Clóvis V. O direito civil brasileiro em perspectiva história e visão de futuro, in Revista dos Tribunais, $\mathrm{n}^{\circ}$ 628, 1988 (agora in FRADERA, Vera Maria Jacob. O direito privado brasileiro na visão de Clóvis do Couto e Silva, Porto Alegre, Livraria do Advogado, 1997, págs 11-12))

17 Ao longo deste trabalho, utilizaremos as expressões "Direito Comercial" e "Direito Mercantil" indistintamente, conforme orientação da Professora PAUlA ANDREA ForGIONI em sua recente tese de titularidade: "No Brasil, alguns acreditam que as expressões direito mercantil, direito comercial e direito empresarial assumiriam significados diversos. O direito mercantil designaria a matéria em sua primeira fase, ligada à disciplina da atividade dos mercadores medievais; direito comercial estaria relacionado ao segundo período, em que os atos de comércio definem os limites da disciplina, e, por fim, direito empresarial seria o nome atualmente correto, porque a empresa é o centro do debate. Contudo, essa distinção é estéril, pois as três expressões são sinônimas. Em todas as fases de sua evolução,esse ramo especial do direito sempre disciplinou a atividade dos agentes econômicos encarregados da geração de riqueza, fossem eles chamados mercadores, comerciantes ou empresários. O traço diferenciador dessa área do direito, e que identifica seus protagonistas, sempre foi o marcado escopo de lucro. Discussões semelhantes quanto ao nome dado à matéria ocorrem na França (droit des marchands, droit commercial e, mais recentemente, droit des affaires), como explica Jean Hilaire (...). Na Itália, a expressão "diritto commerciale" é tradicional (...), enquanto "diritto imprenditoriale" não é comum. Há também quem entenda que as expressões "direito mercantil" ou "mercadores" seriam demasiadamente antigas. Nota-se, porém, que possuem a mesma raiz da palavra "mercado', nada podendo haver de mais contemporâneo para designar aqueles que nele atuam. Os estadunidenses empregam com freqüência o substantivo Merchant e o verbo to merchandise. Anota Scandizzo que a palavra mercado nasce do particípio passado do verto latino mercari, que significa comercial (...)" (A evolução do direito comercial brasileiro: da mercancia ao mercado, São Paulo, RT, 2009, pág. 13, nota de rodapé $\left.\mathrm{n}^{\mathrm{o}} 1\right)$.

18 Textualmente, a Lei de 18 de Agosto de 1769 dispunha “(...) que aquella boa razão, que o sobredito preambulo determinou, que fosse na praxe de julgar subsidiaria não possa nunca ser a da authoridade extrinseca destes, ou daquelles textos de Direito Civil, ou abstractos, ou ainda com a concordancia de outros; mas sim, e tão sómente: ou aquella boa razão, que consiste nos primitivos principios, que contém verdades essenciaes, intrinsecas, e inalteráveis, que a Ethica dos mesmos Romanos havia estabelecido, e que os Direitos Divino, e Natural, formalizarão para servirem de Regras Moraes, e Civis entre o Christianismo: ou aquella boa razão, que se funda nas outras Regras, que de universal consentimento estabeleceo o Direito das Gentes para a direccção, e governo de todas as Nações civilisadas: ou aquella boa razão, que se estabelece nas Leis Politicas, Economicas, Mercantis e Maritimas, que as mesmas Nações Christãs tem promulgado 
Verificou-se, portanto, no Brasil, no tocante ao Direito Comercial, solução parecida com aquela que o individualismo crítico deu para identificação do usus modernus pandectarum em Portugal: na falta de legislação, doutrina, jurisprudência e, em decorrência do pacto colonial, até mesmo de usos e costumes mercantis, socorreu-se da aplicação da legislação estrangeira pelos tribunais nacionais.

\section{$\$ 7^{0}$ - Indícios da penetração de inovações jusracionalistas no Direito}

Comercial brasileiro. A análise da historiografia jurídica nacional permite entrever que o dispositivo da Lei de 18 de Agosto de 1769 que mandava aplicar as leis das nações cristãs cultas e polidas, em matéria de Direito Mercantil, permitiu, com efeito, a penetração de inovações jusracionalistas no Direito Comercial brasileiro.

As fontes testemunham que o enunciado normativo da Lei da Boa Razão não foi letra morta, aplicando-se, efetivamente, a legislação estrangeira tanto em Portugal, quanto no Brasil ${ }^{19}$.

\section{$\$ 8^{\circ}$ - Possível resultado da influência jusracionalista no Código Comercial}

brasileiro. Não se pode, contudo, exagerar o resultado da aplicação da legislação estrangeira, afetada pelas reformas do século XVIII, como determinante no caráter do Código Comercial brasileiro.

Com efeito, não se verificou a introdução de novas ideias que modificaram, em outras nações, o próprio âmago do sistema de direito privado. É o caso, por exemplo, do art. 1583 do Code Civil de 1804, cujo enunciado normativo consagrava o princípio de que basta o consenso para transmissão dos direitos reais ${ }^{20}$.

com manifestas utilidades, do socego publico, do estabelecimento da reputação, e do augmento dos cabedaes dos povos, que com as disciplinas destas sabias, e proveitosas Leis vivem felices a sombra dos thronos, e debaixo dos auspícios dos seus respectivos Monarcas, e Principes Soberanos.

Sendo muito mais racionavel, e muito mais coherente que nestas interessastes materias se recorra antes em caso de necessidade ao subsidio proximo das sobreditas Leis das Nações Christãs, iluminadas, e polidas, que com ellas estão resplandecendo na boa, depurada e sã Jurisprudencia (...) do que ir buscar em boas razões, ou sem razão digna de attender-se, depois de mais de 17 seculos o socorro às Leis de huns Gentios (...)”.

${ }^{19}$ A este respeito ver, infra, 2.2.3, $\$ 3^{\circ}$, em que se abordarão as consequências jurídicas da abertura dos portos brasileiros à navegação internacional, apontando, na ocasião, a aplicação dos códigos estrangeiros, como permitido pela Lei da Boa Razão, por conta da escassez de regramento mercantil na até então colônia do Brasil. A escassez era não apenas legislativa, mas também de costumes comerciais, na medida em que, até aquele momento, vivia-se sob regime de exclusivo metropolitano.

${ }^{20}$ Sobre a importância do referido artigo para a sistemática de todo um código, TEIXEIRA DE FREITAS, na Introdução à Consolidação das Leis Civis, repreende José HoMEM CORREIA Telles: "O systema inteiro de um Codigo depende muitas vezes de uma só disposição. Se o respeitavel autor do Digesto Portuguez, 
A influência da legislação estrangeira no Código Comercial brasileiro fazse sentir, sem dúvida alguma, no aspecto formal: a organização das diferentes partes, livros e títulos daqueles três mencionados códigos, quais sejam, o francês, o espanhol e o português, é análoga a do Código de 1850.

Do ponto de vista material, um aspecto em especial chama a atenção: o enunciado normativo do artigo 129, inciso 3, do Código Comercial, revela a influência do art. 1108, inciso IV, do Code Civil francês de 1804, ao impor a causa como requisito de validade de um contrato.

O art. 1108 do Código Civil francês está (e sempre esteve) assim redigido:

\section{"Article 1108}

Quatre conditions sont essentielles pour la validité d'une convention :

Le consentement de la partie qui s'oblige ;

Sa capacité de contracter;

Un objet certain qui forme la matière de l'engagement ;

Une cause licite dans l'obligation". (destacamos)

Por sua vez, o revogado art. 129 do Código Comercial brasileiro de 1850, tinha a seguinte redação:

imbuído nos principios de um falso Direito Natural que não combina com os interesses da sociedade as relações entre as partes contractantes, resolveu adoptar a disposição do Art. 1583 do Codigo Civil Francez, um dos corolários da outra disposição generica do Art. 711; era necessario, que não tivesse omittido as diversas restricções desse Codigo, que servirão de correctivo (se bem que incompleto) ao seu systema espiritualista, e acautelarão funestos abusos.

Ao contrario, se por um lado foi indifferente á todas as exigências da sua innovação, tomando-a isoladamente, e não como applicação de uma theoria, que substitue o pensamento ao facto; por outro lado foi contradictorio, exluindo a tradição, e ao mesmo tempo conservando as regras do Direito Romano e do Direito Portuguez, á respeito da tradição ficta, e symbolica e dos actos solemnes de posse" (Consolidação das leis civis, $3^{\mathrm{a}}$ ed., Rio de Janeiro, Garnier, 1876 (ed. fac-similar, Brasília, Senado Federal, 2003), págs. LIX-LX).

Em certa medida, cremos que a crítica dirigida por TEIXEIRA DE FREITAS a CORREA TELLES poderia ser também dirigida aos responsáveis pela elaboração do Código Comercial brasileiro, na medida em que adotaram, no art. 129, inc. 3, regra inovadora, adotada pelo Código Civil francês por inspiração de RoBERT JOSEPH POTHIER, que em nada corresponde à tradição jurídica luso-brasileira e que não foi acompanhada de outras disposições que a complementariam. Este é o ponto que passaremos a expor em seguida no corpo de texto. 
“Art. 129 - São nulos todos os contratos comerciais:

1. que forem celebrados entre pessoas inábeis para contratar;

2. que recaírem sobre objetos proibidos pela lei, ou cujo uso ou fim for manifestamente ofensivo da são moral e bons costumes;

3. que não designarem a causa certa de que deriva a obrigação;

4. que forem convencidos de fraude, dolo ou simulação (art. 828);

5. sendo contraídos por comerciante que vier a falir, dentro de

40 (quarenta) dias anteriores à declaração da quebra (art. 827).(destacamos)

J.X. Carvalho de MendonçA afirma, expressamente, em seu Tratado de direito comercial, que a regra do art. 129 é cópia do Código Civil francês ${ }^{21}$.

Vê-se que, a exemplo do Code Civil de 1804, o Código Comercial brasileiro, em seu art. 129, inciso 3, cominava, para a hipótese de falta de causa, a invalidade do contrato.

A regra não se coaduna com a tradição jurídica luso-brasileira; mais do que isso, a causa, vista como requisito de validade de um negócio jurídico é criação inovadora do jusracionalismo que teve repercussão legislativa no Code Napoleon, ponto sobre quê trataremos no capítulo 3, infra.

\$9 - Hipótese científica do presente trabalho. O presente estudo terá como finalidade investigar os meios pelos quais a teoria francesa da causa - dita subjetiva -, que prevê a invalidade do contrato pela falta de causa, chegou ao art. 129, inciso 3, do Código Comercial.

21 "O Cod. Commercial, no art. 129, n.3, cópia infeliz do art. 1.108 do Cod. Civil francez, exige como essencial nos contratos commerciaes a designação de uma causa certa, da qual se deriva a obrigação" (CARVAlho DE MENDOnÇA, José Xavier. Tratado de direito comercial brasileiro, vol. I, Rio de Janeiro, Freitas Bastos, 1963, pág. 49). 
Provoca surpresa encontrarmos em um diploma central do sistema de Direito Privado brasileiro, que esteve em vigência, por completo, por mais de 153 anos e que ainda vige em sua segunda parte, que regula o comércio marítimo, um enunciado normativo que destoa significativamente da tradição jurídica seguida pelo Direito Civil.

Mesmo se comparado ao todo do Código Comercial, o enunciado do art. 129 , inciso 3 , também destoa. Como já acenado nesta Introdução ${ }^{22}$, uma das principais inovações do jusracionalismo em relação ao direito privado, é a eficácia real do contrato de compra e venda. O consensualismo ganhou espaço na legislação de diversos países, entre eles Itália e o próprio Portugal, além, é claro, da França ${ }^{23}$. No entanto, no Código Comercial brasileiro que, a julgar pelo art. 129, inciso 3 , estaria voltado às novas tendências, a eficácia real da compra e venda não se observa, prendendo-se o Código à tradição romanística ${ }^{24}$.

Assim, a hipótese do presente trabalho é a de que a penetração da inovação jusracionalista consubstanciada na ideia da invalidade do contrato pela falta ou defeito de causa teria ocorrido por meio do permissivo contido no $\S 9^{\circ}$ Lei da Boa Razão, somado à sua concretização nos termos dos Estatutos da Universidade de Coimbra de 1772, no sentido de permitir e estimular a busca de soluções para o direito mercantil na legislação, jurisprudência e doutrina estrangeiras ${ }^{25}$.

$\$_{10}^{0}$ - Premissas metodológicas. Para empreendermos a investigação a que nos propomos, devemos analisar, além dos textos historiográficos e de historiografia jurídica, três espécies de fontes, que se complementam na investigação histórico-jurídica: a) as fontes legislativas brasileiras e estrangeiras, que no âmbito de nosso tema assumem

${ }^{22}$ Cfr. supra $\$ 7^{\circ}$, nota de rodapé $\mathrm{n}^{\circ} 21$.

${ }^{23}$ No Código Civil francês, a norma que estabelece o princípio consensual em relação ao contrato de compra e venda está no art. 1583. No Código Italiano de 1942, foi estipulada uma regra geral para os contratos com efeitos reais: "Art. 1376. Contratto con effetti reali - Nei contratti che hanno per oggetto il trasferimento della proprietà di una cosa determinata, la costituzione o il trasferimento di un diritto reale ovvero il trasferimento di un altro diritto, la proprietà o il diritto si trasmettono e si acquistano per effetto del consenso delle parti legittimamente manifestato". O Código Civil português de 1966 também prevê a eficácia real do contrato de compra e venda: "Art. 879 - A compra e venda tem como efeitos essenciais: a)A transmissão da propriedade da coisa ou da titularidade do direito; (...)".

${ }^{24}$ O Código Comercial brasileiro manteve, nos arts. 126 e 197 a 200, a distinção entre título e modo de aquisição, afastando a transmissão consensual de direitos reais.

${ }^{25}$ Não se pode afirmar que a metodologia de integração de lacunas inaugurada pelas reformas pombalinas teve repercussão decisiva na formação do Direito Privado brasileiro, como teve em relação ao direito português. Não o teve - e não pretendemos afirmar o contrário. Entretanto, não se pode negar, diante das evidências das fontes, que tal metodologia teve aplicabilidade no Brasil, especificamente em relação ao Direito Mercantil, cuja doutrina em língua portuguesa ainda era substancialmente incipiente. 
especial importância; b) as fontes doutrinárias, nacionais e estrangeiras; c) as fontes jurisprudenciais.

A seleção dos textos e fontes a serem analisados ao longo de um trabalho historiográfico está intimamente relacionada com a metodologia a ser empregada, bem como a visão de história que tem o pesquisador, de sorte que alguns pontos devem ser esclarecidos.

Em primeiro lugar, é oportuno ressaltar que, recentemente, as pesquisas históricas se voltaram de forma bastante decidida para as questões culturais, relativizando o paradigma materialista de análise histórica. As histórias política e econômica não mais ocupam posições central nos livros, cedendo espaço para outros aspectos, como a questão da identidade, da religião, educação, e outros temas anteriormente negligenciados nas pesquisas de ordem histórica ${ }^{26}$.

Em um trabalho como este que agora apresentamos, que trata, grosso modo, de uma determinada linha de influência jusfilosófica que influenciou o direito comercial brasileiro, natural seria trazer para o texto aspectos de história econômica que ajudaram a traçar o perfil de nossa legislação mercantil. Entretanto, o próprio objeto da pesquisa - uma teoria jurídica Iluminista que teria sido transplantada para o ordenamento brasileiro impõe uma aproximação mais intelectualista do que materialista. Não se pode questionar que, mesmo diante das últimas orientações metodológicas à pesquisa histórica, os aspectos

${ }^{26}$ Peter BURKe assim se manifesta a respeito deste movimento de expansão dos campos de pesquisa do historiador: "De acordo com o paradigma tradicional, a história diz respeito essencialmente à política. Na ousada frase vitoriana de Sir John Seeley, Catedrático de História em Cambridge, 'História é a política passada: política é a história presente'. A política foi admitida para ser essencialmente relacionada ao Estado; em outras palavras, era mais nacional e internacional, do que regional. No entanto, não incluía a história da Igreja como uma instituição e também o que o teórico militar Karl von Clausewitz entendia como 'a continuação da política por outros meios', ou seja, a guerra. Embora outros tipos de história - a história da arte, por exemplo, ou a história da ciência - não fossem totalmente excluídos pelo paradigma tradicional, eram marginalizados no sentido de serem considerados periféricos aos interesses dos 'verdadeiros' historiadores.

Por outro lado, a nova história começou a se interessar por virtualmente toda a atividade humana. 'Tudo tem uma história', como escreveu certa ocasião o cientista J.B.S. Haldane; ou seja, tudo tem um passado que pode em princípio ser reconstruído e relacionado ao restante do passado. Daí a experessão 'história total', tão cara aos historiadores dos Annales". (A nova história, seu passado e seu futuro, in BuRKE, Peter (org.) New perspectives on historical writing, Oxford, Blackwell, 1991 (trad. port. Magda Lopes. A escrita da história: novas perspectivas, São Paulo, UNESP, 1992), págs. 10-11).

A Escola dos Annales, referida por BURKE no trecho acima transcrito, é, justamente, um movimento de reação ao paradigma tradicional de estudo da história - a metodologia rankeana, em referência ao historiador alemão LEOPOLD VON RANKE. Marca-se o início da Escola, muito associada às novas perspectivas de estudo da história - brevemente enunciadas no corpo de texto e na transcrição acima - com a fundação da revista Annales, em 1929, por LuCIEN FEB VRE e MARC BLOCH. 
materiais não podem ser deixados de lado. Tais aspectos, todavia, não constituem o objeto direto de nossas atenções.

Outro ponto que pode causar espanto no leitor é o fato de tratarmos, como objeto de pesquisa, de um enunciado normativo do Código Comercial já revogado pelo Código Civil vigente. Qual o interesse no estudo de um dispositivo que já não tem aplicação no ordenamento? Este aspecto merece, igualmente, esclarecimentos.

No âmbito das pesquisas jurídicas, bem como nos trabalhos doutrinários e manualísticos, estamos habituados a encontrarmos resenhas históricas como intróitos das dissertações e teses acadêmicas. Não é grande o volume de obras especificamente voltadas à pesquisa da história jurídica, o que pode causar a impressão de que, na realidade, o estudo da História do Direito serve, unicamente, para justificar o direito vigente, ou para que se utilize o método hermenêutico da interpretação histórica.

Essa impressão, no entanto, é falsa. Assim como qualquer estudo de ordem histórica - história social, econômica, cultural, etc. - a história do direito, tendo como objeto de estudo uma realidade intimamente relacionada à própria existência do homem em sociedade, é um fim em si próprio. Como qualquer outro aspecto da vida humana, o direito é uma realidade histórica. O conhecimento dos fatos passados, as experiências - jurídicas ou não - que formam nosso modo de vida têm uma inegável importância em si mesmo ${ }^{27}$.

O último ponto a ser esclarecido neste parágrafo diz respeito a uma derradeira questão metodológica deste trabalho. Já mencionamos acima que tratamos de um aspecto técnico muito particular da dogmática jurídica privatista - a teoria francesa sobre a causa - em seu vitual acolhidamento pelo Código Comercial brasileiro de 1850. Não pretendemos, portanto, realizar uma reconstrução totalizante de uma experiência jurídica. Antes de tudo, procuraremos enfocar as questões dogmáticas, buscando entender as implicações práticas do problema.

\footnotetext{
${ }^{27}$ Nesse sentido manifesta-se FRANZ WIEACKER: "Hoje, já não constitui tarefa do historiador fundamentar historicamente os direitos actuais, como, outrora, na Idade Média e até à época barroca; ou tornar possível a interpretação histórica do direito vigente, como ainda se pretendia na ciência jurídica do séc. XIX. Tais tarefas podem ainda hoje continuar a interessar, uma vez por outra, os juristas; no entanto, elas não constituem o objectivo directo da investigação histórico-jurídica.

Dir-se-á, antes, que a missão cognitiva da história do direito - como a de qualquer outra história - não se fundamenta no material previamente estabelecido dos dados e factos históricos e na sua utilidade para o presente, mas na historicidade da nossa própria existência. Na medida, porém, em que a história do direito acaba por recorrer necessariamente, quanto a esta questão, à própria experiência do direito, tornam-se seu objecto quaisquer domínios da história em que, em geral, possa ser encontrada a experiência humana do direito. Ela acaba por ser a História, sob o ponto de vista da experiência humana do direito. (Cit. (nota n. 6), pág. 4).
} 
Não é possível ignorar a orientação metodológica tão bem sintetizada por MARIO BRETONE, em sua História do direito romano. O mencionado autor abre sua obra propondo uma abordagem que vai além dos textos jurídico-normativos e doutrinários, pois esses fornecem dados parciais sobre a experiência jurídica. BRETONE exemplifica seu argumento com a elaboração de um testamento, "ato capital para o cidadão romano”: “(...) nenhuma obra jurídica, pela sua própria natureza, está em condições de nos restituir o mundo emotivo e afectivo de quem escrevia, ou fazia escrever, o próprio testamento (percebemos, por vezes, apenas o seu eco enfraquecido) ${ }^{28, "}$.

Páginas adiante, ao discutir em que sentido se deve entender uma história jurídica, BRETONE esclarece que a sociologia - ou, ainda, a história social - fornece uma perspectiva externa que impede o historiador do direito de cair no tecnicismo, abrindo caminho para entendimento do papel do direito e dos juristas no sistema social global. No entanto, o direito, mesmo observado sobre a ótica da sociologia, não deixa de ser um fenômeno técnico, e deve ser analisado como tal ${ }^{29}$.

Portanto, acompanhando a orientação de BRETONE, guiar-nos-emos ao longo do trabalho pela premissa de que a história social não pode deixar de acompanhar a história jurídica, sob pena de se prender a tecnicismos estéreis, sem qualquer relevância na prática cotidiana $^{30}$. No entanto, o foco principal estará nas implicações técnicas do problema que nos propomos estudar, pois, como já salientamos, não se trata, nas dimensões deste

${ }^{28}$ BRETONE, Mario. Storia del diritto romano, Bari, Laterza, 1987 (trad. port. Isabel Teresa Santos e Hossein Seddighzadeh Shooja, História do direito romano, Lisboa, Estampa, 1998), pág. 19.

${ }_{29}^{29}$ Assim se manifesta o autor: "O direito, observado sociologicamente, não deixa por isso de ser um fenômeno técnico até 'demasiado difícil'. Ele deve ser investigado nestas suas dificuldades, nos métodos e nos processos de que se serve, nas doutrinas e nas manifestações literárias, nas 'filosofias' que o acompanham, nas necessidades que satisfaz (ou descura) e nos efeitos que produz sobre toda a organização social”. (BRETONE, Mario, op. cit. (nota 28), págs. 29-30).

${ }^{30}$ Neste sentido, é eloquente o exemplo fornecido pelos historiadores PETER GARNSEY e RICHARD SALLER. Tradicionalmente, o jurista, apoiado nas fontes, enxerga a família romana como uma organização autoritária, em que ao paterfamilias eram atribuídos amplos poderes, inclusive de vida e de morte (vitae necisque potestas), sobre seus descendentes diretos. No entanto, os referidos historiadores utilizaram- evidências demográficas para negar uma organização familiar tão centrada no patria potestas como estamos habituados a conceber. A diferença de idade entre pais e filhos, em outras palavras, a distância temporal entre uma geração e outra, era, em média, muito grande, de sorte que, ao tempo em que o filho, ou filha, estava apto a casar, o pai já não estava vivo e, portanto, não interferia no casamento. Além disso, GARNSEY E SALLER analisaram fontes literárias que demonstram que as relações entre os familiares, especialmente entre pais e filhos, eram afetuosas e que as questões patrimoniais a respeito da formação do peculium não eram levantadas, de modo que a questão da incapacidade do filius família para constituição de seu próprio patrimônio não tinha reflexo na vida prática.

Tais fatores resultavam, na conclusão dos autores, em uma família muito menos autoritária e centrada no poder do pai do que poderia sugerir a leitura das fontes exclusivamente jurídicas. Cfr. GARNSEY, Peter; SALLER, Richard. The Roman empire: economy, society and culture, London, Duckworth, 1987, págs. 126147. 
trabalho, de elaborar uma reconstrução totalizante - no sentido de uma história total, bem ao gosto dos Annales -, uma vez que, nos dizeres de POPPER, transcritos por BRETONE, "a totalidade não pode ser concebida como objecto ou campo da investigação histórica ${ }^{31, "}$

$\$^{\$ 11^{\circ}}$ - Plano de trabalho. Para realizarmos a análise a que nos propomos, dividiremos a exposição em três capítulos. No primeiro deles lançar-se-ão os olhos sobre o Iluminismo jurídico português; em seguida, no segundo capítulo, procuraremos verificar as consequências do Iluminismo jurídico sobre o direito mercantil e traçar os principais aspectos da formação histórica do Direito Comercial brasileiro; por fim, o último capítulo destina-se à análise do regramento da causa no Código Comercial de 1850, verificando-se, em um primeiro momento, as origens jusracionalistas da invalidade do contrato por falta de causa, e, em seguida, confirmando-se a adoção do regramento semelhante ao do Código Civil francês no Código Comercial brasileiro.

${ }^{31} \mathrm{O}$ autor prossegue a sua transcrição: "Uma investigação determinada (e uma investigação por definição só pode ser determinada) que teria por objecto o todo: uma espécie de convite à confusão, à indeterminação, a uma historiografia mística" (BRETONE, Mario, op. cit. (nota 28), pág 28). 


\section{Capítulo 1 - O Iluminismo jurídico em Portugal e suas consequências em relação à metodologia de integração de lacunas no Direito luso-brasileiro.}

Plano do Capítulo - O presente capítulo pretende fornecer uma breve visão sobre os principais aspectos do Iluminismo jurídico português.

O capítulo será dividido em duas partes. Na primeira delas, verificaremos de que forma se deu a introdução das ideias Iluministas em Portugal, por meio da obra de LUís ANTÓNIO VERNEY. Em seguida, veremos como o pensamento de VerNEY foi transposto para o âmbito legislativo, por meio das chamadas "reformas pombalinas".

Como já vimos na Introdução, as reformas empreendidas ao longo do reinado de D. José I, pelas mãos de seu Ministro Marquês de Pombal, tiveram forte inspiração iluminista e reflexos permanentes na história do direito português e, também, do direito brasileiro. Especificamente em relação ao direito comercial, o $\S 9^{\circ}$ da Lei da Boa Razão dispunha ser aplicável, como legislação subsidiária "aquela boa razão, que se estabelece nas Leis Políticas, Economicas, Mercantis, e Maritimas" das nações cultas e polidas da Europa; posteriormente, os Estatutos da Universidade de Coimbra de 1772 que realizavam a interpretação autêntica do dispositivo, fixando a legislação estrangeira como critério de aferição do usus modernus pandectarum.

\section{1 - A introdução das ideias iluministas em Portugal: Luís António Verney e o Verdadeiro Método de Estudar.}

\subsection{1 - VerneY, a publicação do Verdadeiro Método de Estudar e as} “cartas a Eccellenza”.

$\$ 1^{\circ}$ - Os “estrangeirados”. A introdução do Iluminismo em Portugal devese ao grupo que ficou conhecido como "estrangeirados". Eram portugueses que passaram 
a residir fora de Portugal - portanto, no "estrangeiro" - e que desejaram ver sua pátria comungar do espírito de renovação que se espalhava pela Europa ${ }^{32}$.

$\S 2^{\circ}$ - O Verdadeiro Método de Estudar. No entanto, deste grupo, nenhum membro merece maior destaque - pelo menos no que se refere ao âmbito jurídico - que a figura de LUÍs ANTÓNIO VERNEY. Esse “estrangeirado" teve publicada, anonimamente, no ano de 1746, a obra epistolar chamada $O$ Verdadeiro Método de Estudar que, com base no Iluminismo italiano, enfrentava os princpais problemas verificados no ensino superior português, ligado, sobremaneira, aos Jesuítas ${ }^{33}$.

A obra foi publicada em dois tomos, totalizando dezesseis cartas. De todas, a que mais de perto interessa à ciência jurídica é a de número XIII. Além do impacto cultural provocado pelo conteúdo mesmo da carta, as ideias de VERNEY nela expostas tiveram acolhimento legislativo nas reformas empreendidas pelo Marquês de Pombal, anos

32 Gomes da Silva, Nuno José Espinosa, op. cit. (nota 11), pág. 461. A este respeito, Luís CABRAL DE MONCADA: "Estavam na moda os memoriais e as cartas-relatórios dirigidas aos govêrnos pelos homens eminentes que se achavam no estranjeiro, quási sempre a pedido dos mesmos governos, contendo ideas e sugestões que estes depois podiam aproveitar ou não; (...)." (Um iluminista português do século XVIII: Luís António Verney, São Paulo, Saraiva, 1941, pág. 33).

A despeito da referência ao grupo estrangeirado no texto, convém noticiar que, recentemente, o conceito foi posto em xeque pela historiografia. Conforme BRUNO FERRAZ LEAL FERREIRA, "com a dissolução do salazarismo, observa-se cada vez mais uma abertura, entre outros adventos, ao marxismo e à historiografia dos Annales. O resultado, até hoje, tem sido contestação às noções que apartavam os ibéricos da 'civilização' da Europa clássica, bem como à ideia de 'bloqueio' da Ilustração em Portugal. A própria noção de 'estrangeirado' foi revista. Jorge Borges de Macedo contestou-a, enxergando-a como uma hispótese que, embora tivesse se mantido, não corresponderia à realidade. Sua fragilidade explicativa é atribuída principalmente à inexistência de uniformidade entre os próprios 'estrangeirados' sobre os mais diversos temas. Não teriam constituído um grupo específico, com ações específicas”. A crítica de BORGES DE MACEDO iniciou um debate acerca da ideia de estrangeirado, havendo quem defendesse a utilização do conceito, e outros que se bateram pelo abandono da palavra. Há consenso, no entanto, quanto a ser difícil caracterizar o grupo estrangeirado com um todo definido e orgânico. (Cfr. FerReIRA, Breno Ferraz Leal. Contra todos os inimigos. Luís António Verney: historiografia e método crítico, Dissertação (USP-FFLCH), São Paulo, 2009, págs. 56-57)

${ }^{33}$ A introdução à primeira edição lê-se o seguinte: "Certo Religiozo da Universidade de Coimbra, omem mui douto, como mostra nas suas cartas; pedio a um Religiozo Italiano, seu amigo, que vivia em Lisboa; que lhe dese algumas instrusoens, em todo o gênero de estudos. O que o dito Barbadinho executa, em algumas cartas: explicando-lhe em cada-uma, o que lhe-parece: e acomodando tudo, ao estilo de Portugal" (VERNEY, Luís António. O verdadeiro método de estudar, tomo I, Valensa, Antonio Balle, 1746, pág. 1).

Mantivemos a indicação bibliográfica do Verdadeiro método comumente usada, embora seja de notar que, na realidade, a obra não foi impressa em Valença por Antonio Balle, e nem se trata esta da primeira edição da obra. A primeira edição, impressa em Nápoles, não pôde circular em Portugal, por conta da proibição imposta pelo tribunal do Santo Ofício. Diante da negativa da Inquisição, VERNEY resolveu recorrer à fraude, fazendo imprimir, novamente em Nápoles, seu Verdadeiro método, apondo o nome de novo editor, Antonio Balle, em Valença. É, justamente, esta edição que está disponível em formato digital no sítio da Biblioteca Nacional de Portugal, acessível pelo seguinte endereço eletrônico: http://purl.pt/118 <último acesso em 10 de novembro de 2010, às 23h48min>. A respeito da história da publicação do Verdadeiro método, veja-se ANDRADE, Antonio Alberto de. Vernei e a cultura de seu tempo, Coimbra, Acta Universitatis Coninbrigensis, 1966, notadamente págs. 171 a 175. 


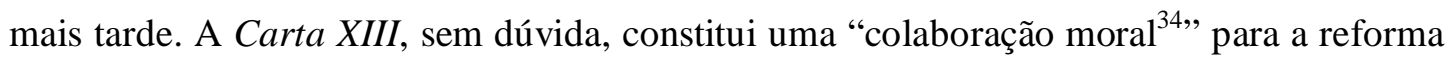
pedagógica prognosticada pelo Compêndio histórico sobre o estado da Universidade de Coimbra no tempo da invasão dos Jesuítas (1771) e levada a efeito pela Reforma dos Estatutos da Universidade de Coimbra $(1772)^{35}$.

$\S 3^{\circ}$ - As cartas e relatórios a “Eccellenza", de 1765-1766. CABRAL DE MoncaDA, em sua obra Um iluminista português do século XVIII: Luís António Verney, publica, anexas, oito cartas e dois relatórios - documentos, até então, inéditos - trocados, entre os anos de 1765 e 1766, entre o autor do Verdadeiro Método com uma autoridade da intimidade do Ministro Pombal, que o se supunha ser o Ministro Francisco de Almada e Mendonça

Sabe-se, contudo, após mais acurados estudos, não se tratar do Ministro Almada a autoridade com quem Verney confidenciava. ANTONIO AlBERTO DE ANDRADE indica tratar-se do então diplomata Ayres de Sá e Melo, que já havia sido, tal como Almada, plenipotenciário português na Itália ${ }^{36}$.

Tais documentos parecem comprovar um contato direto entre Luís António Verney e o governo português. CABRAL DE MONCADA julga que deles resulta "uma completa identidade de espírito entre as convicções do sábio e a obra do estadista, e ainda mais do que isso, se é possível: uma plena consciência por parte do primeiro de cumprir uma missão cultural e cívica transcendente, fornecendo ao Govêrno do seu país, por portas-travessas e sob o favor de secretos e indirectos entendimentos, muitas sugestões e conselhos que, - curiosa coincidência! - não tardariam em ser aproveitados e, muitas vezes, passado algum tempo, convertidos em $1 \mathrm{ei}^{37}$,.

\footnotetext{
${ }^{34}$ A expressão é de CABRAL DE MonCADA, Luís, op. cit. (nota 32), pág. 15.

${ }^{35}$ A respeito, veja-se POUSADA, op. cit (nota 4), págs. 59-60, nota de rodapé no 123 . O mesmo autor conclui, mais adiante (pág. 61) que "Luís António Verney é o responsável mediato pelas reformas empreendidas pelo Marquês de Pombal a partir da segunda metade do século XVIII. Isso fica evidente a partir da leitura da Carta XIII do Verdadeiro Método de Estudar: nela são lançadas críticas ao ensino e à prática do Direito em Portugal - ao mesmo tempo em que se recomenda à Sua Majestade a reformulação do estudo jurídico na Universidade de Coimbra, bem como substanciais alterações quanto ao exercício da prática forense".

${ }^{36}$ A análise a respeito da personalidade destinatária das cartas de Verney está em ANDRADE, Antonio Alberto de, op. cit. (nota 41), págs. 495-498. Acompanhando a conclusão de ANDRADE, no sentido de ser Ayres de Sá o correspondente de VERNEY, veja-se FERREIRA, Breno Ferraz Leal, op. cit. (nota 32), pág. 44.

${ }^{37}$ Idem, Ibidem, págs. 16-17. Os documentos publicados por CABRAL DE MONCADA, conforme indicado no corpo de texto, estão na mesma edição ora citada da obra sobre Verney.
} 
Empreenderemos uma breve análise das cartas e relatórios após exposição dos principais aspectos ligados ao ensino e à prática do direito contidos no Verdadeiro Método de Estudar.

\subsection{2 - Os principais aspectos ligados à ciência jurídica contidos no} Verdadeiro Método de Estudar.

A Carta XIII do Verdadeiro Método de Estudar contém críticas em relação ao estado do ensino jurídico em Portugal e as principais alterações que, no pensamento de Verney, deveriam ser empreendidas ${ }^{38}$.

\section{$\S 1^{\circ}$ - Críticas ao ensino jurídico em Portugal.}

De forma muito contundente, VERNEY inicia suas críticas ao ensino jurídico no Portugal de seu tempo apontando a absoluta falta de método com que os estudos eram dirigidos na Universidade de Coimbra. Em suas palavras, o estudante "só estuda depois que é Doutor, e quer opor-se às Cadeiras. Nam digo que estuda com metodo: mas mete na cabesa muito texto, e suas respostas, que é o que lhe-basta" ${ }^{39}$ ".

Em aberta oposição ao estilo escolástico-bartolista, dominante, até então, para o ensino do direito, o autor aduz que a lógica formal como era ensinada ao seu tempo - baseada no silogismo - é despicienda ao jurista, uma vez que acostuma o entendimento a "mil sutilezas metafísicas sem fundamento algum; obriga o Logico, que se guia por-ela, a fazer o mesmo na-Lei ${ }^{40 "}$.

${ }^{38}$ Utilizaremos como guia dos aspectos relevantes do Verdadeiro Método para este tópico o estudo realizado por POUSADA, Estevan Lo Ré, op. cit. (nota 4).

${ }^{39}$ VERnEY, Luís António, op. cit. (nota 33), tomo II, pág. 142.

${ }^{40}$ Idem, Ibidem, loc. cit. A crítica ao estudo da lógica, como realizado até então, era uma nota comum ao período, como destaca JOAQUIM DE CARVALHO: "Como este [o compêndio Instituições dialécticas, de PEDRO DA FONSECA], os outros compêndios de lógica aristotélica fatigavam o espírito sem o esclarecerem, deixando pela vida fora a sensação da inutilidade e do tempo perdido; por isso se compreende que se tornasse objeto de chacota quem na vida real tomasse a sério o verbalismo das distinções lógicas e que o mestre do infante D. Antônio, irmão de D. João V, o engenheiro Manuel de Azevedo Fortes (1660-1748), tivesse escrito no antelóquio da Lógica racional, geométrica e analítica (Lisboa, 1744) que 'semelhante estudo mais servia para embaraçar e confundir as nossas idéias do que para aperfeiçoar as operações do nosso entendimento, que é o fim principal da Lógica'”. (A crítica da segunda escolástica portuguesa, introdução a LOCKE, John. Ensaio philosophico sobre o entendimento humano. Resumo dos Livros I e II, recusado pela mesa Real Censória e agora dado ao prelo com introdução e apêndice, Coimbra, Biblioteca da Universidade, 1950 
Todavia, um dos pontos centrais - e que terá sérios impactos nas reformas empreendidas na segunda metade do século XVIII por Pombal - das críticas de VERNEY ao ensino jurídico diz respeito à primazia do direito nacional português. $\mathrm{O}$ autor observa que os bacharéis egressos da Universidade de Coimbra colavam grau sem nunca terem lido a legislação pátria, pois se dava excessiva atenção ao direito romano justinianeu ${ }^{41}$.

Como medida corretiva a esse problema, VERNEY propõe uma reforma educacional, para valorização do direito do Reino, nos moldes da que havia sido realizada na França por Luís XIV ${ }^{42}$.

Outro ponto decisivo no pensamento do autor sobre o ensino jurídico é aquele em que se defende a necessidade do estudo do Direito Natural. Logo nas primeiras páginas da Carta XIII, VERNEY aduz que a Ética em sentido estrito considera o "sumo bem" e o modo para consegui-lo; ou expõe os diversos ofícios e obrigações do homem para se conformar com a reta razão, isso é, a jurisprudência natural ou universal; ou, quando considera as ações do homem enquanto são úteis à comunidade civil, a que se chama política. Toda essa normação tem a mesma origem, pois a lei natural, a lei divina e a lei das gentes são a mesma lei com diversos respeitos. Portanto, para o autor, claro está que quem não sabe jurisprudência natural não pode entender a jurisprudência romana. Justamente por não se entender esse ponto é que, aduz VERNEY, não se regulam bem os estudos jurídicos ${ }^{43}$.

(agora in O nascimento da moderna pedagogia: Verney, Rio de Janeiro, Documentário/PUC-Rio, 1979, pág. 20).

41 "No-Principio do quinto-ano deve o estudante, ler o direito Portuguez, ou as leis municipais: notando as coizas, em que diversifica do-Comum. Sem duvida é digno de admirasam, que saiam os omens dasUniversidades, falando muito nas leis de Justiniano, que só servem, faltando a lei municipal; e nada saibam daquela lei, por-que se-ám-de governar! Isto é o mesmo que um Teologo, o qual, despois de doutorado, saise das-escolas, sem saber os proceitos gerais, da-lei Divina" (Idem, Ibidem, pág. 178). Observe-se, no entanto, que VERNEY ao apontar como método adequado o histórico compendiário não despreza o estudo da história romana e do direito romano. $\mathrm{O}$ autor indicava, efetivamente, que, para compreensão da história universal era imprescindível o estudo da história romana. Conforme o autor, seria necessário "conhecer perfeitamente" a história romana, "pois quem a-sabe bem, tem o comentário perpetuo, da-Lei”. Em seguida, VERNEY afirma que, tendo-se lido a história romana, deve o estudante ler a história do Direito Civil, principalmente do Direito Civil romano (VERNEY, Luís António, op. cit. (nota 33), tomo II, pág. 165)

42 "Muito bem a-conhecem, em outros Reinos estrangeiros, em que se-estabelecèram cadeiras, do-Direito municipal. O que especialmente fez Luiz XIV em Fransa: cuja memoria será eterna, na republica Literaria. Sendo admiravel naquele grande omen, que, pasando toda a sua vida ocupado, em trabalhozisimas guerras, nam ouve Rei algum no-mundo, que igualmente promovèse o comercio, e as letras: pois só ele fundou mais, e mais utis Academias, que os antecedentes todos; e as melhores, que se-vejam na Europa. Emfim este estudo, tambem se-deve fazer na Universidade: e talvez que asim se-poupasem muitas demandas, que nacem, da-ignorancia da-Lei” (Idem, Ibidem, págs. 178-179).

${ }^{43}$ Idem, Ibidem, págs. 140-141. 
A seguir, o autor também indica a insuficiência do direito justinianeu na formação dos juristas que ocupariam funções na administração estatal. A preocupação de VERNEY em relação a este aspecto está relacionada ao costume de os bacharéis se ocuparem dos negócios do Estado, seja no âmbito econômico, seja no âmbito político. Neste contexto, revela-se a insuficiência do conhecimento das leis romanas para eventuais relacionamentos com povos de cultura diversa da européia. Diz VERNEY que, com a formação que recebem os homens de Estado, ao se colocar diante deles uma questão que envolve, por exemplo, direito de guerra, procurariam eles as soluções nos textos imperiais romanos. Alguns, ainda, procurariam acrescentar algum texto colhido das fontes do Direito Canônico. No entanto, esses documentos não serão sempre suficientes. O autor oferece o exemplo de uma questão surgida entre uma nação européia com turcos ou com chineses. Argumenta VERNEY que as fontes romanas teriam para os povos de outras culturas a mesma autoridade que teriam para o europeu o Alcorão ou os escritos de Confúcio. Deste modo, mais adequado seria recorrer ao direito das gentes e ao direito natural, e não ao direito romano ${ }^{44}$.

$\S 2^{\circ}$ - Propostas de alterações no ensino jurídico. Os pensadores do século XVIII, Verney incluído, tinham uma ideia muito clara do que era necessário destruir para desobstruir o caminho rumo às Luzes. No entanto, a forte consciência em relação àquilo que deveria ser derrubado não foi acompanhada, em todas as áreas, por uma nova construção, pela ideia do que deveria ser construído no lugar das ruínas da escolástica. Também neste campo, Verney não foi exceção ao seu tempo. Registra JOAQUIM DE CARVAlHo que Verney é, fundamentalmente crítico: “com rubor da vergonha e com a consciência viril de quem cumpre uma boa ação decisiva, bateu-se pela renovação do plano

\footnotetext{
44 "E fundados nisto, nam tem dificuldade de rezolverem, toda controversia, sobre o direito da-Paz, e daGuerra, dos-Patos, e tudo o mais que pode suceder, entre Nasoens, e Nasoens. Mas por-pouco que seconsidere a materia, se-achará, que estes documentos nam sam bons, para rezolver tudo. Suponhamos que nace uma controversia, entre uma nasám Europeia, com os Turcos, ou Chinas, ou Malabares, sobre a violasam da-paz, ou coiza semelhante; julga V.P. que ám-de ter autoridade entre eles, as Pandetas de Justiniano, ou as Decretais, ou Moralistas? Tanta como se aqueles nos-alegasem, com o Alcoram: os outros com Confucio, ou semelhante doutor dos-seus. Nestes cazos ou se-trate com Aziaticos, ou Europeos, ou qualquer outra gente racionavel, é necesario ter promtas, nam as leis Romanas, mas as das-Gentes, ou dodireito Natural, abrasados por-todos, os que uzam da-razam: para poder mostrar, a justisa da-nosa cauza, de que se-tiram as solusoens, dos-tais cazos: e de que se-devem tirar, nam só naqueles, mas ainda nos-que sucedem, entre Nasoens cultas” (Idem, Ibidem, pág. 151).
} 
de estudos e pela reforma da mentalidade, mas a sua razão de militante estava mais bem instruída do que devia remover-se do que devia fundar-se ${ }^{45}$ ".

Todavia, especificamente no que se refere à ciência do direito, VERNEY oferece um plano claro, um novo sistema de estudo, de forma geral, bem acabado e dirigido por uma firme convicção intelectual. Tanto assim, que suas ideias foram postas em prática em seguida, quando da reforma dos Estatutos da Universidade de Coimbra $(1772)^{46}$.

VERNEY, ao iniciar a exposição de seu "sistema de estudar leis", aduz que, ao longo da história do direito romano, os patrícios passaram a invejar os plebeus após terem esses "usurpado" algumas magistraturas. Para se distinguirem desses últimos e serem necessários na República, os patrícios "inventáram mil formulas novas de Direito, e as ocultaram com todo cuidado". A partir deste ponto é que passou o estudo do direito a ser dificultoso ${ }^{47}$.

Dado todo o itinerário histórico do direito civil, é patente a necessidade do estudo histórico para o jurista. VERNEY afirma, inclusive, que é pela história que o estudante deve começar o estudo da $1 \mathrm{lei}^{48}$.

O autor aduz que "tendo visto quais são as fontes, do Direito todo, deve passar a estudar a istoria Romana. E como esta nam se-pode intender bem, se intender ao menos, a istoria Universal; por iso deve estudá-la. E no mesmo tempo tomar alguma ideia, da Cronologia, e seus principios: e juntamente procurar na carta Geografica, os lugares, e provincias, de que se-faz mensam: pois desta sorte, nam só intenderá melhor a Istoria; mas conservará perpetuamente, a memoria dela ${ }^{49}$ ".

Tendo lido a história romana, o estudante deve passar à história do direito civil, principalmente do direito civil romano. Com isso, estar-se-ia preparado para as Instituições de Justiniano, "advertindo-se porem, de fugir de toda a sorte de comentarios". Os comentários são prejudiciais ao estudo, pois muitos são feitos por "idolatras de

${ }^{45}$ CARvalHo, Joaquim de, op. cit. (nota 40), pág. 33.

${ }^{46}$ Ainda na esteira das lições de JOAQUIM DE CARVAlHo, deve-se observar que a palavra sistema, como empregada no texto, deve ser entendida em sentido amplo, uma vez que, por se colocar contra os grandes sistemas da escolástica, a atitude de VERNEY como filósofo "consistiu em proclamar que não tinha Filosofia, quer se entenda por esta palavra a ordenação em um sistema de um conjunto de pensamentos relacionados entre si com travação lógica, que o desabrochamento da problematicidade, isto é a transformação em problema do que passa despercebido ou se dá como indubitado". (Cit. (nota 40) pág. 36).

${ }^{47}$ VERNEY, Luís António, op. cit. (nota 33), tomo II. 161.

${ }^{48}$ Idem, Ibidem, pág. 164.

${ }^{49}$ Idem, Ibidem, pág. 165. 
Justiniano", que supõem que o Imperador teve revelações divinas e, por isso, nunca afirmam que sua obra tem falhas e incongruências; ao contrário, querem justificar tudo ${ }^{50}$.

Portanto, após a formação histórica preparatória, o estudante deveria lançarse ao estudo das Leis Imperiais em uso, despidas de qualquer comentário, e expostas de acordo com a sua ordem natural ${ }^{51}$.

Ao longo das críticas e propostas contidas na Carta XIII, VERNEY revela sua preferência pelo método histórico compendiário, que deveria substituir o estilo escolástico bartolista.

O que foi apregoado por Verney ao longo da Carta XIII do Verdadeiro Método de Estudar encontrou guarida nas reformas pombalinas, principalmente na Lei da Boa Razão e na Reforma Universitária de 1772, por meio de que se levou a efeito importantes modificações no ensino jurídico e no sistema de direito subsidiário ao ordenamento português ${ }^{52}$.

\subsection{3 - Cartas e relatórios dirigidos por LUÍS ANTÓNIO VERNEY a} “Eccellenza”.

$\$^{0}$ - O papel de Verney nas reformas pombalinas. A análise da Carta XIII do Verdadeiro Método de Estudar sem dúvida revela uma evidente conexão espiritual

\footnotetext{
${ }^{50}$ Idem, Ibidem, págs. 166-167.

${ }^{51}$ Cfr. PousAdA, Estevan Lo Ré, op. cit. (nota 4), pág. 65. A respeito do uso moderno do direito romano, VERNEY afirma que não pode o jurista ler apenas a lei romana, pois é "sem duvida, que a experiencia mostra, que, sem a noticia de outras coizas, nam poderá no-estilo prezente, julgar de muitas daquelas leis, que foram feitas para outro estilo: a mudansa dos-costumes, e governos é cauza, que muitos oje nam sirvam. Ja nam temos os mesmo magistrados, e oficiais publicos. Nam se-fala ja de servos no mesmo sentido, de manumisoens, libertos, libertinos, colonos, censitos, e outras especies de agricultores: nem de veteranos, e outros uzos da-guerra. O pátrio poder nam tem oje, o mesmo vigor. Tudo isto oje é inutil: e por-isso se querem outras noticias" (VERNEY, Luís António. Verdadeiro, op.cit. (nota 33), págs. 176-177).

Sobre a redução das leis imperiais a sua ordem natural, VERNEY aduz que "Quando o moso vai lendo, pode notar, os que sam de maior utilidade, e por-lhe um final; para se-aplicar a eles, com o tempo. Mas o principal ponto está, em reduzir as Leis, à sua ordem natural; como deviam ser dirigidas, se acazo Triboniano, e seus companheiros conhecesem, (que certamente nam conhecèram) aquilo a que nós chamamos, Metodo" (Idem, Ibidem, pág. 171).

${ }^{52}$ Neste sentido, Estevan Lo Ré Pousada: “Conforme indica Estevan lo Ré Pousada, o “preconizado por Luís António Verney foi efetivamente implementado pelo Marquês de Pombal, notadamente através da Lei de 18 de agosto de 1769, do Compêndio histórico sobre o estado da Universidade de Coimbra de 1771 e dos Novos Estatutos Universitários de 1772, por meio dos quais importantes reformas foram promovidas nos âmbitos do direito subsidiário e do ensino jurídico ${ }^{52 "}$ (Cit. (nota 4), pág. 66).
} 
entre o pensamento de seu autor e as reformas empreendidas na segunda metade do século XVIII pelo Ministro Pombal.

Não pode - e nem se pretende - relativizar o papel do Verdadeiro Método na introdução das ideias Iluministas em Portugal. No entanto, no dizer de CABRAL DE MONCADA, "depois de lidas estas cartas, dificilmente poderá deixar-se de concordar com Camilo, quando o grande escritor, no seu Perfil do Marquês, chamou a Verney o mais fecundo oráculo do grande estadista ${ }^{53}$,.

Não é possível, no entanto, valorizar excessivamente o papel destas cartas e relatórios nas reformas da segunda metade do século XVIII. O próprio Verney queixa-se, em carta datada de 8 de fevereiro de 1786, dirigida ao Padre Joaquim de Foyos, que teve a chance de iluminar a nação portuguesa, mas que nunca lhe haviam sido dados os meios para tanto ${ }^{54}$.

Ou seja, apesar de as correspondências revelarem a existência de mais do que uma conexão espiritual entre Verney e as reformas pombalinas, o papel do estrangeirado no direcionamento das reformas tem que ser realizado com cautela.

As cartas e relatórios tratam de assuntos muito diversos, como veremos a seguir. Todavia, alguns dos principais pontos envolvidos nas reformas não têm lugar nas correspondências, tendo sido expostos por VERnEY apenas no Verdadeiro Método de estudar.

Dada a importância histórica dos documentos, bem como as poucas análises sobre eles empreendidas nas pesquisas jurídicas, passaremos a uma breve exposição de seu conteúdo, procurando estabelecer as conexões pertinentes com as reformas pombalinas.

${ }^{53}$ CABRAl de MonCADA, Luís, op. cit. (nota 32), pág. 16.

54 Esclarece VerneY, na mencionada carta, como Portugal, por meio de seus Ministros, o deixou sem meios de cumprir aquilo que julgava ser sua missão: "E como tinha composto obras em todas as faculdades (tirando medicina) para uso da nosa nasam, e tinha gasto muito dinheiro niso, e não tinha as rendas necesarias para tantos gastos, foi necesario que parese, e me puzese a observar o que lá e cá faziam, para assim ver o que eu devia fazer. E deste modo ficamos parados por alguns anos, nos quais porem eu fui sempre limando algumas obras. Escrevi entam de Pisa ao Marquès de Pombal, que tendo-me o Rei D. José prometido de me pagar a impresam de todas as minhas obras, como já tinha pago os primeiros tres tomos (Apparatus ad Phil., De re logica e De re metaphysica), de que lhe nomeava as testemunhas, madase verificar a ditar ordem para a Fisica. Mas o Marqués não respondeo nada, e somente me nomeou pouco depois (carta regia de 13 de abril de 1768) Secretario Regio para servir a Corte com o Ministro Almada, que entam tornou para cá" (Carta de 8 de fevereiro ao Padre Joaquim Foyos, in CABRAL DE MONCADA, Luís, op. cit. (nota 32), pág. 146).

Convém mencionar que ANTONIO ALBERTO DE ANDRADE questiona ser o Padre Joaquim Foyos o verdadeiro destinatário da carta de 8 de fevereiro de 1786. As razões para tanto estão na op. cit. (nota 33), págs. 498-499. 
$\S 2^{\circ}$ - Visão geral do conteúdo das cartas. ${ }^{55}$ Como já acenamos acima, as cartas tratam de assuntos diversos entre si. A nota comum a todas elas, no entanto, é a constante crítica aos jesuítas, a quem Verney atribuía a responsabilidade por toda sorte de males do reino e de sua vida pessoal

Com efeito, na carta de 17 de julho de 1765, Verney aponta os efeitos nocivos que a educação no molde dos Jesuítas operava nos príncipes, especialmente no que se refere à má gestão do erário público. Para VERNEY, o soberano agia, em muitas localidades, como titular do dinheiro público, quando, na verdade, deveriam comportar-se como meros administradores, visando somente a vantagem do povo. Apenas por meio da educação e boas leituras esse método inidôneo dos príncipes, incutido pelos jesuítas, seria erradicado $^{56}$.

Outro ponto, em certa medida recorrente ao longo das cartas, que está em plena consonância com o espírito do século XVIII é a ideia de ciência, disseminada pelos homens iluminados, como guia para o desenvolvimento e felicidade das nações. A ciência contribuiria, inclusive, para afastar das nações que por ela fossem iluminadas males que se julgava dizerem respeito apenas ao âmbito religioso, como o combate aos bruxos e $\operatorname{diabos}^{57}$.

Para VERNEY, inclusive, os Jesuítas e a Inquisição, apresentam-se como obstáculos à ciência, ao progresso e à introdução de muitas coisas necessárias e úteis ${ }^{58}$. Neste ponto, o autor faz diversas interessantes observações sobre o regramento do processo

\footnotetext{
${ }^{55}$ Não serão abordados todos os aspectos tratados nas cartas em vista da falta de pertinência temática com nossa dissertação. Para uma visão esquemática do conteúdo geral, veja-se, novamente, ANDRADE, Antonio Alberto, op. cit. (nota 33), págs. 495-496.

56 “(...) i Principi non intendono questa importante verità, ch'eglino non sono già padroni de' danari pubblici, ma meri amministratori, pel solo vantaggio de' popoli. E non si trova niun nè Consigliere nè Confessore, che gli spieghi, e inculchi, questa verità Evangelica. Anzi tutti gli danno idee contrarie fin dall'infanzia prima: di cui nascono i disordini, che alla giornata vediano: e quello spirito di Dispotismo, e persecuzione, com cui opprimono tutti quei, che non sono del loro sentimento, e che col dovuto rispetto glie lo vogliono far intendere nè casi necessarj (...). Quel pensare Gesuitico radicato in tutti i capi fin dall'infanzia, è diventato un altra natura: ci vogliono molti anni, molta lettura, e gran buona educazione per sradicarlo". (Carta de 17 de julho de 1765, in CABRAL DE MONCADA, Luís. Um iluminista, op. cit. (nota 32), págs. 152-153).

57 “Or privati i Regni di quegli grand'uomini, che soli potevano aprire gli occhi ai suoi nazionali, ed introdurre col buon gusto delle Scienze, il retto pensare, senza di cui nè in Politica, nè in verun' altra matéria si fa cosa niuna buona; (...)". (Carta de 17 de julho de 1765, in CABRAL DE MONCADA, Luís. Um iluminista, op. cit. (nota 32), pág. 150). "E si é osservato, che i diavoli hanno gran paura de'paesi, dove si sà bem Filosofia, Medicina, Legge, e Teologia: imperocchè non si arriscano mai in tali luoghi, di far patto com niun uomo. (...) Ed in Francia, dove nel principio del secolo passato bruciavano gente per Stregoni; dopo rinata la Filosofia, ed istituita l'Academia delle Scienze, non si trovarono più: e solo gastigarono alcuni, perche dicevano la bugia de esserli". (Carta de 25 de novembro de 1765, in Idem, Ibidem, págs. 159-160).

58 “'L'altro punto dell' Inqusizione sara sempre, Ecc. a , un ostacolo terribile al buon gusto delle Scienze, ed al progresso, e introduzione di molte cose necessarie, e utili”. (Idem, Ibidem, pág. 157).
} 
no tribunal do Santo Ofício português, propondo modificações para seu melhor funcionamento. As propostas têm o condão de promover a humanização da Inquisição, já que um tribunal eclesiástico deve usar sempre mais cautela, mais simplicidade e mais misericórdia ${ }^{59}$.

Para efetivação de um novo modelo, mas condizente com os princípios da fé cristã, VERNEY bate-se pela publicidade do processo, indispensável para que o acusado possa se defender a contento ${ }^{60}$; também se opõe à utilização da tortura como meio de prova $^{61}$; apregoa a presunção de inocência ${ }^{62}$ e faz apologia do in dubio, pro reo ${ }^{63}$.

Dois outros tópicos tratados por VERNEY nas cartas a Ayres de Sá dizem respeito às qualidades que deve ter o bom Ministro de Estado, que é tratado na missiva de 24 de novembro de 1766; e, por fim, discorre sobre o que qualifica como abuso da Corte Romana de instituir uma Ordem com a mesma Cruz da Ordem portuguesa, destacando a passividade dos responsáveis portugueses para a solução da controvérsia (Carta de 23 de janeiro de 1766).

\section{2 - As Reformas Pombalinas}

\section{$\S 1^{\circ}$ - Jusracionalismo $e$ "usus modernus pandectarum” em Portugal. A}

introdução do Iluminismo jurídico em Portugal, o que se deu, principalmente, como já vimos acima, pela obra de LUÍS ANTÓNIO VERNEY, teve importantes consequências. Realizaram-se importantes reformas em instituições jurídicas centrais do ordenamento, como, por exemplo, no direito das sucessões ${ }^{64}$.

59 "Ed un Tribunale Eclesiastico deve usare più catele, più facilità, più misericórdia. (...); per qual cagione non usa di quei mezzi blandi, che insegna la Religione, e la prudenza?” (Idem, Ibidem, pág. 160).

60 "Non è possibile che um uomo si possa difendere rettamente senza esaminar bene Il suo processo (...). Non si deve far mistero de’processi (...).” (Idem, Ibidem, págs. 159-160)

61 "Una persona debole tormentata, confessa sempre Il delitto, che non há fatto (...). Pel contratio una persona di muscolatura forte, e di faccia tosta, nega sempre Il delitto commesso (...)”. (Idem, Ibidem, pág. 163).

62 "Per quanto sia delinquente un Reo, è un uomo como noi: e prima della sentenza niuno lo può maltrattare". (Idem, Ibidem, pág. 162).

63 "E la stessa ragione insegna, esser meglio, che quache Reo dubbio resti impunito, che gastigare um innocente. Sendo questo Il massimo interesse della Società umana, che niuno ingiustamente sia vessato". (Idem, Ibidem, pág. 164).

${ }^{64}$ Assim informa BRAGA DA CRUZ: "Nenhuma dessas reformas [legislativas do período pombalino], porém, adquiriu tanto vulto como aquela que atingiu a regulamentação jurídica do direito sucessório e que forma o conteúdo de várias leis pombalinas que se tornaram famosas, dominadas, todas elas, pela idéias de hostilidade à sucessão testamentária e endeusamento da sucessão legítima, como única forma de sucessão consentânea com a razão natural: - Pela lei de 25 de junho de 1766, estabeleceram-se numerosos entraves à 
No entanto, a verdadeira revolução no ordenamento português - e também brasileiro - se deu por conta das modificações empreendidas no sistema de direito subsidiário.

Especialmente em relação ao direito privado, as Ordenações do Reino eram extremamente lacunosas e continham inúmeras referências às fontes subsidiárias. Por tal razão, bastou que se modificassem os critérios hermenêuticos e de integração de lacunas para que todo o regramento privatístico fosse reformado de maneira decisiva.

Foi esse o papel exercido pela Lei de 18 de agosto de 1769, a afamada Lei da Boa Razão, complementada pelos Estatutos da Universidade de Coimbra de 1772.

Conforme já salientado na introdução, o Direito Civil brasileiro sofreu, com a reforma pombalina, influência menor do que o Direito Civil português ${ }^{65}$. No entanto, o Direito Comercial, em nossa hipótese, não passou tão incólume quanto o direito civil pela introdução do jusracionalismo e do usus modernus no ordenamento luso-brasileiro. A substancial modificação na metodologia de integração de lacunas teve reflexos no nosso Direito Mercantil muito maiores do que no nosso Direito Civil, o que teve como consequência, ainda segundo nossa hipótese, a inserção de certas figuras jurídicas características do período jusracionalista, como a causa regrada nos moldes do Código Civil francês, como veremos no terceiro e último capítulo desta dissertação.

Portanto, é de fundamental importância que exponhamos acuradamente os principais aspectos da reforma pombalina, em especial no que concerne ao direito subsidiário, para que possamos compreender os mecanismos de introdução no direito comercial brasileiro de aspectos que não condizem com a nossa tradição jurídica.

\footnotetext{
liberdade de testar, considerando-se nulos os testamentos feitos durante doença grave, excpto se os contemplados eram parentes próximos do testador, e considerando-se nulas, igualmente, tôdas as deixas testamentárias feitas em favor de quem redigiu o testamento ou de qualquer parente seu até o quarto grau, ou da Ordem religiosa ou corporação eclesiástica a que o mesmo escriba do testamento pertencesse.

- Pela famosa lei de 9 de Setembro de 1769, novas restrições se impunham à liberdade testamentária, restaurando-se a velha distinção medieval entre bens herdados dos antepassados e bens adquiridos pelo próprio trabalho ou indústria, e estabelecendo-se, quanto aos primeiros, uma indisponibilidade quase total, cujos beneficiários seriam os parentes próximos, até o $4^{\circ}$ grau inclusive, contado segundo o direito canônico". (Formação, op. cit. (nota 15), págs. 40-41)

${ }^{65}$ Cfr. supra, Introdução, $\S 5^{\circ}$.
} 


\subsection{1 - Breve aceno sobre o sistema de integração de lacunas anterior à} reforma pombalina.

\section{$\$^{\circ}$ - O sistema inaugurado pelas Ordenações Afonsinas ${ }^{66}$. A partir do} momento em que as fontes de direito romano e seus respectivos comentários, bem como o direito canônico, passam a se sobrepor às fontes castelhanas como direito subsidiário em Portugal, surge a preocupação de se hierarquizar tais fontes, a fim de se reduzir hesitações na jurisprudência dos tribunais ${ }^{67}$.

A primeira providência legislativa neste sentido veio com a promulgação das Ordenações Afonsinas. O pensamento jurídico da época colocava o problema do direito subsidiário como uma questão de limites entre a jurisdição civil e canônica. A própria localização sistemática do título referente à hierarquização das fontes subsidiárias, no Livro II, título VIIII - sendo que os oitos títulos anteriores tratam das relações entre Igreja e Estado, e os 14 que se seguem regulam os demais privilégios e regalias reconhecidos ao clero pelo poder civil. Também a epígrafe dada ao texto é significativa: "Quando a Ley contradiz aa Degratal, qual dellas se deve guardar"

Curiosamente, no entanto, a primeira disposição do título VIIII diz respeito à prevalência das leis do reino sobre as disposições de direito romano. Segue-se então, a disposição de que, não havendo leis do reino sobre o caso, que seja julgado conforme as leis imperiais ou os sagrados cânones ${ }^{69}$.

O critério geral de prioridades estava assim definido: em matéria de ordem temporal, a prioridade é do direito romano, exceto se da sua aplicação resultar pecado; nos problemas jurídicos de ordem espiritual ou nos problemas de ordem temporal em que a aplicação do direito romano resultar em pecado, deve-se observar o direito canônico ${ }^{70}$.

\footnotetext{
${ }^{66}$ Recorreremos constantemente, a partir daqui, à obra de BRAGA DA CRUZ, Guilherme. O direito subsidiário na história do direito português, in Obras esparsas, vol. II, $2^{\mathrm{a}}$ parte, Coimbra, Acta Universitatis Conimbrigensis, 1981, págs. 245-436.

${ }^{67}$ Para uma visão completa deste processo, cfr. BRAGA DA CRUZ, Guilherme. Ibidem, págs 247-295.

${ }^{68}$ Idem, Ibidem, pág. 247.

69 "Estabelecemos, e poemos por Ley, que quando alguu caso for trazido em pratica, que seja determinado por algua Ley do Regno, ou estillo da nossa Corte, ou custume dos nossos Regnos antigamente usado, seja per elles julgado, e desembargado finalmente, nom embargante que as Leyx Imperiaaes acerca do dito caso ajam desposto em outra guisa, porque onde a Ley do Regno dispõem, cessam todaslas outras Leys, e Direitos; e quando o caso, de que se trauta, nom for determinado por Ley do Regno, mandamos que seja julgado, e findo pelas Leyx Imperiaaes, e pelos Santos Canones".

${ }^{70}$ Cfr. BRAGA DA CRUZ, Guilherme. O direito subsidiário, op. cit. (nota 66), págs.302-303.
} 
O texto afonsino oferece um exemplo para ilustrar o caso da prevalência do direito canônico quando da aplicação do direito romano resulte pecado. Trata-se da usucapião pela posse de má fé por trinta anos, possível conforme o direito justinianeu; contudo, sendo esse regramento observado, acarretar-se-ia, necessariamente, pecado ao possuidor, "o que nom devemos a consentir".

Em seguida, justifica-se o porquê de se obedecer ao direito canônico: “(...) em tal caso devemos necessariamente obediencia ao Padre Santo, e aa Santa Igreja, de que os Canones procedem, a qual nõ devemos em nenhuu caso aos Emperadores, de que as Leyx Imperaaes procedem; (...)". A respeito dessa passagem justificativa, BRAGA DA CRUZ observa tratar-se de uma afirmação solene da doutrina da isenção da iurisdictio Imperii, além de "invocar uma razão positiva da observância do direito canónico (a obediência devida ao Papa e à Igreja) contra uma razão meramente negativa do acatamento do direito romano (o não dever Portugal obediência ao Imperador)(...) $)^{71 " .}$

Para a hipótese em que a situação não fosse regulada nem pelas leis, estilo ou costume do reino, nem pelas disposições de direito romano ou pelo direito canônico, determinavam as Ordenações que se observassem as glosas de ACÚRSIO incorporadas ao às fontes romanas. Não havendo nas referidas glosas a solução do caso, dever-se-iam verificar a opinião de BÁRTOLO, independentemente do que dissessem os demais doutores, pois sua opinião é comumente mais conforme a razão ${ }^{72}$.

Por fim, esgotada a hierarquia nos termos supra sem que se pudesse ainda encontrar uma solução, determinavam as Ordenações que se levasse o caso à apreciação pessoal do monarca $^{73}$; proceder-se-ia do mesmo modo caso não houvesse matéria de

\footnotetext{
${ }^{71}$ Idem, Ibidem, pág. 305.

${ }^{72}$ Eis a passagem completa das Ordenações Afonsinas: "2 ITEM. E se o casom de que se trauta em pratica, nom fosse determinado por Ley do Regno, ou estillo, ou costume suso dito, ou Leyx Imperiaaes, ou Santos Canones, entom mandamos que se guardem as grosas d'Acursio, encorporadas nas ditas Leyx. E quando pelas ditas grosas o caso nom for determinado, mandamos, que se guarde a opiniom de Bartholo, nõ embargante que os outros doutores diguam o contrairo; porque fomos bem certo, que assy foi sempre usado, e pratica em tempo dos Reyx meu Avoo, e Padre da gloriosa memória; e ainda nos parece, pólo que já alguas vezes vimos, e ouvimos a muitos Leterados, que sua opiniom comunalmente he mais conforme aa razom, que a de nenhuu outro Doutor; e em outra guisa seguir-sai grande confusom aos Desembargadores, segundo se mostra per clara esperiencia”. O restante da passagem, por pertinência ao corpo de texto, será transcrito na nota abaixo.

73 “2 ITEM. (...)E acontecendo caso, ao qual per nenhuum dos ditos modos nom fosse previsto, mandamos que notifiquem a Nos pêra o determinarmos; porque nom tamsomente taaes determinaçoões som desembargo naquelle feito, que se trauta, mais som Ley pêra desembargarem outro semelhante".
} 
pecado, fosse omissa a solução nos textos de direito romano e houvesse solução diversa no direito canônico e nas glosas dos doutores ${ }^{74}$.

$\S 2^{\circ}$ - As modificações insertas pelas Ordenações Manuelinas em sua versão primitiva, pelas Ordenações Manuelinas de 1521 e o regramento do direito subsidiário nas Ordenações Filipinas. As Ordenações Manuelinas impressas entre 1512 e 1514, que, como cediço, foram substituídas por outras, impressas e divulgadas em 1521, limitaram-se a reproduzir, em linhas gerais, no regramento do direito subsidiário, as disposições das Ordenações Afonsinas ${ }^{75}$. No entanto, uma importante modificação foi realizada e transitou para a versão definitiva das mesmas Ordenações, bem como para as Ordenações Filipinas.

O enquadramento sistemático do título referente ao direito subsidiário continuou o mesmo: inserto no Livro II, em meio às disposições pertinentes às relações entre Igreja e Estado. A importante alteração a que logo acima aludimos é a seguinte: as glosas de Acúrsio só seriam aplicadas "quando por a commu opiniã dos doctores nõ fore reprouadas". Proceder-se-ia o mesmo em relação a BÁRTOLO, embora sua opinião prevalecesse ainda que reprovadas por alguns doutores ${ }^{76}$.

Ficou, assim, introduzida, no ordenamento português, a força normativa da communis opinio doctorum, que passa a prevalcer sobre a exegese de ACURSIO e sobre as opiniões de BÁRTOLO.

Nas Ordenações Manuelinas de 1521, há já um rompimento com as Ordenações Afonsinas e com sua versão primitiva, embora a localização sistemática não tenha sido alterada, permanecendo, portanto, no Livro II. A epígrafe, no entanto, já revela uma "tomada de consciência, por parte do novo legislador, de que o problema em questão transcende o restrito âmbito dum conflito entre a 'ley' e a 'decretal', entre o direito romano

\footnotetext{
${ }^{74} 3$ ITEM. Despois desto achamos outra duvida. Se acontecesse caso, em o qual nõ fosse matéria de pecado, o qual nom fosse determinado per Ley do Regno, nem per estillo da nossa Corte, nem per custume dos nossos Regnos, nem per Ley Imperial, e fosse determinado per Canones per huu modo, eplas grosas, e Doutores das Leyx per outro modo, se se guardará em tal caso o textos dos Canones, ou as grosas dos Doutores das Leys Imperiaaes. E a causa desta duvida he, porque as grosas, e Doutores do Direito Civil se gundam per Leyx Imperiaaes, as quaaes alegam a provar sua teençom: em tal caso seja remetido aa nossa Corte, e guarde-se sobre ello a nossa determinaçom”.

${ }^{75}$ Não tivemos ocasião de consultar a primeira versão das Ordenações Manuelinas. As informações contidas no texto sobre elas provém de BRAGA DA CRUZ, Guilherme. O direito subsidiário, op. cit. (nota 75), págs. 308-320.

${ }^{76}$ Cfr. Braga DA CRUZ, Guilherme. O direito subsidiário, op. cit. (nota 66), pág. 330. A transcrição do trecho das Ordenações está conforme a do autor na localização citada.
} 
e o direito canónico, ou entre a jurisdição dos dois poderes (civil e eclesiástico) de que aqueles ordenamentos jurídicos são a expressão ${ }^{77}$ ". A nova epígrafe, agora no Livro II, título V, foi assim redigida: "Como se julguaram os casos, que nom forem determinados por Nossas Ordenaçõens".

Mais uma vez, reitera-se a precedência das fontes jurídicas do reino sobre quaisquer outras. No entanto, já enfrentando a questão do direito subsidiário, o novo regramento abandona a distinção entre problemas jurídicos de ordem espiritual e de ordem temporal. Tudo é reconduzido ao critério único do pecado, "o que implica, como é óbvio, um alargamento do campo de aplicação do direito romano em detrimento do direito canónico (...), ${ }^{, 78}$.

A redação das Ordenações Manuelinas de 1521 elimina a incongruência contida na versão primitiva, que havia sido tomada das Ordenações Afonsinas: eliminou-se do texto a explicação que se dava sobre a prioridade do direito canônico em casos de pecado pela obediência devido "ao Padre Santo e aa Santa Igreja", obediência essa que não era devida ao imperador. Com isso, substitui-se a razão de ordem negativa de acatamento do direito romano, por outra positiva, que era a "boa razam em que sam fundadas". Nas palavras de BRAGA DA CRUZ, com isso, acaba-se a incongruência de se invocar "no próprio texto que ordenava a aplicação subsidiária do direito romano, justamente, a razão por que não lhe é devida obediência",79.

$\mathrm{Na}$ hipótese de o caso não poder ser resolvido nem conforme o direito canônico, nem conforme o direito romano, assim como nas Ordenações anteriores, mandase observar a glosa de ACÚRSIO, os comentários de BÁRTOLO, mantendo-se a restrição da versão primitiva em relação à communis opinio ${ }^{80}$.

${ }_{78}^{7 d}$ Idem, Ibidem, pág. 334.

78 Idem, Ibidem, pág. 337. Estava assim redigido o proêmio do Título V, Livro II, das Ordenações Manuelinas de 1521: "Quando alguu caso for trazido em practica, que seja determinado por algua Ley de Nossos reynos, ou Estilo de Nossa Corte, ou Custume em os ditos reynos, ou em casa hua parte delles longamente vsado, e tal que por Dereito se deua guardar, seja per elles julguado, nom embarguante que as Leys Imperiaes acerca do dito caso desponham em outra maneira, porque onde a Ley, Estilo, ou Custume do Reyno despoem, cessem todas as outras Leys e Dereitos. E quando o caso de que se trauta nom for determinado por Ley, Estilo, ou Custume do Reyno, Mandamos que seja julguado, sendo materia que tragua pecado, por os Santos Canones. E sendo materia que nom tragua pecado, Mandamos que seja julguado pólas Leys Imperiaes, posto que os Sacros Canones determinem o contrairo, as quaes Leys Imperiaes Mandamos soomente guardar pola boa razam em que sam fundadas".

${ }^{79}$ CRUZ, Guilherme. O direito subsidiário, op. cit. (nota 66), págs. 340-341.

80 " 1 . E se o caso de que se trauta em pactica nom for determinado por Ley do reyno, ou Estilo, ou Custume suso dito, ou Leys Imperiaes, ou Santos Canones, entam Mandamos que se guardem as Grosas de Acursio encorporadas nas ditas Leys, quando por comum opiniam dos Doutores nom forem reprouadas, e quando por 
Assim como nas Ordenações Afonsinas, para os casos de o problema não ter solução por meio de nenhuma das fontes enumeradas ${ }^{81}$, bem como quando não se envolvesse pecado e fosse tratado somente, mas de maneira diversa, pelos cânones, glosas e doutores, dever-se-ia remeter ao arbítrio do monarca ${ }^{82}$.

O regramento do direito subsidiário traçado pelas Ordenações Manuelinas em sua versão definitiva foi inteiramente acolhido pelas Ordenações Filipinas de 1603, com algumas modificações de ordem formal. A alteração mais significativa deu-se em relação à posição sistemática do título pertinente, agora posto no Livro III, junto ao regramento do direito processual. A mudança sistemática revela que "só agora, em começos do século XVII, se rompeu a última amarra que prendia o problema do direito subsidiário à ideia inicial - que dominara por completo o texto afonsino e o texto manuelino de 1513-1514(?) - dum conflito de jurisdições entre o poder temporal simbolizado pelo direito romano, e o poder eclesiástico simbolizado pelo direito canónico" ${ }^{83}$.

as ditas grosas o caso nom for determinado, Mandamos que se guarde a opiniam de Bartolo, nom embarguante que alguus Doutores teuessem o contrairo, saluo se a comum opiniam dos Doutores, que despois delles escreueram, for contraira, porque a sua opiniam commumente he mais conforme aa razam".

81 " 2 . E acontecendo caso, ao qual por ninhuu dos ditos modos fosse prouido, Mandamos que o notifiquem a Nós, pêra o Determinarmos; porque nom soomente taees determinaçoens sam desembarguo daquelle feito que se trauta, mas sam Ley pera desembarguarem outros semelhantes".

823 ITEM. Se acontecesse o caso o qual nom fosse materia de pecado, e nom fosse determinado por Ley do Reyno, nem Estilo da Nossa Corte, nem Custume de Nossos Reynos, nem Ley Imperial, e fosse determinado por os Textos dos Canones por huu modo, e por Grosas, e Doutores das Leys por outro modo, Mandamos que tal caso seja remetido a Nós, e guarde-se sobre ello Nossa Determinaçam".

${ }^{83}$ BRAGA DA CRUZ, Guilherme. O direito subsidiário, op. cit. (nota 66), pág. 348. O texto integral do título LXIV do Livro III das Ordenações Filipinas, referente ao regramento do direito subsidiário, ficou assim redigido: "Como se julgarão os casos, que não forem determinados por as Ordenações. Quando algum caso fôr trazido em pratica, que seja determinado per alguma Lei de nossos Reinos, ou stylo de nossa Côrte, ou costume em os ditos Reinos, ou em casa huma parte delles longamento usado, e tal, que por Direito se deva guardar, seja per elles julgado, sem embargo do que as Leis Imperiaes acerca do dito caso em outra maneira dispoem; porque onde a Lei, stylo, ou costume de nossos Reinos dispoem, cessem todas as outras Leis e Direito.

E quando o caso, de que se trata não fôr determindo por Lei, stylo, ou costume de nossos Reinos, mandamos que seja julgado sendo materia, que traga peccado, per os sagrados Canones.

E sendo materia, que não traga pecado, seja julgado pelas Leis Imperiaes, posto queos sagrados Canones determinem o contrario.

As quais Leis Imperiaes mandamos, sómente guardar pola boa razão em que são fundadas.

1. E se o caso, de que se trata em pratica, não fôr determinado por Lei de nossos Reinos, stylo, ou costume acima dito, ou Leis Imperiaes, ou pelos sagrados Canones, então mandamos que se guardem as Glosas de Accursio, incorporadas nas ditas Leis, quando por commum opinião dos Doutores não forem reprovadas; e quando pelas ditas Glosas o caso não fôr determinado, se guarde a opinião de Bartolo, por que sua opinião commumente he mais conforme à razão, sem embargo que alguns Doutores tivesse o contrario; salvo, se a commum opinião dos Doutores, que depois delle escreveram, fôr contraria.

2. E acontecendo caso, ao qual por nenhum dos ditos modos fosse provido, mandamos que notifiquem a Nós, para o determinarmos; porque não sómente taes determinações são desembargo daquelle feito que se trata, mas são Leis para dezembargarem outros semelhantes. 


\section{$\S^{\circ}$ - Distorções na aplicação das fontes subsidiárias e a necessidade de}

reforma. Como vimos logo acima, o texto das Ordenações Afonsinas referente ao regramento do direito subsidiário acentuava, expressamente, a prioridade do direito nacional sobre o direito romano ${ }^{84}$.

Noticia BRAGA DA CRUZ que a opção do legislador de destacar, expressamente, a prioridade do direito nacional, revela a existência de um problema em aberto, "possivelmente, apenas o abuso, por parte de alguns tribunais - por sua iniciativa ou a invocação das partes litigantes - de aplicar o direito romano com menosprezo do direito pátrio, pois esse abuso verificou-se durante todo o Antigo Regime, apesar do texto explícito das Ordenações ${ }^{85}$ ".

A despeito da existência de um problema em aberto, a prevalência do direito nacional sobre o direito romano justinianeu nunca foi posta em dúvida, pelo menos em teoria. Alguns praxistas se manifestavam no sentido de que, em Portugal, o direito comum não era o direito romano, mas o direito nacional. Houve mesmo quem defendesse que, em nome da prioridade do direito nacional, as lacunas das leis do reino deveriam ser preenchidas por meio da analogia, com recurso, portanto, à outras leis nacionais. Somente após o esgotamento de tal possibilidade, é que se recorreria às fontes de direito subsidiário $^{86}$.

A prática, no entanto, revela que, frequentemente, o texto das Ordenações não foi respeitado, especialmente no que se refere aos seguintes pontos: $a$ ) desrespeito à determinação de aplicação estritamente subsidiária do direito romano; $b$ ) controvérsia a respeito da delimitação do direito romano subsidiário; $c$ ) vacilações quanto ao critério de aferição da communis opinio doctorum; $d$ ) interpretação restritiva das leis pátrias quando em confronto com disposições destoantes do direito romano justinianeu.

A despeito do destaque dado nas três Ordenações à prioridade do direito nacional, os tribunais recorrentemente aplicavam o direito romano com menosprezo do

3. E sendo o caso, de que se trata tal, que não seja materia de peccado, e não fosse determinado per Lei do Reino, nem stylo de nossa Côrte, nem costume de nossos Reinos, nem Lei Imperial, e fosse determinado pelos textos dos Canones per hum modo, e per as Glosas e Doutores das Leis por outro modo, mandamos que tal caso seja remettido a Nós, para darmos sobre isso nossa determinação, a qual se guardará".

${ }^{84}$ Ver, supra, $1.2 .1, \S 1^{\circ}$, nota de rodapé $\mathrm{n}^{\circ} 69$.

${ }^{85}$ BRAGa DA CRUZ, Guilherme. O direito subsidiário, op. cit. (nota 66), pág. 301, nota de rodapé no 1 .

${ }^{86}$ Ver, a respeito, Braga DA CRuZ, Ibidem, pág. 354; também, PousAdA, Estevan Lo Ré. Preservação, op. cit. (nota 4), págs. 52-53. 
direito nacional. Portanto, nem sempre fora observada, na prática, a subsidiariedade do direito romano em Portugal $^{87}$.

Como vimos $\operatorname{acima}^{88}$, a versão definitiva das Ordenações Manuelinas acrescentou uma justificava de ordem positiva para a aplicação do direito romano: mandava-se guardar as leis imperiais somente pela boa razão em que são fundadas. O critério da conformidade à boa razão para aplicação do direito romano comportou diferentes atitudes interpretativas. Um grupo doutrinário entendia que se devia recusar a aplicação do direito romano quanto este se revelasse contrário à boa razão; por outro lado, houve quem procurasse estabelecer uma conexão entre a boa razão das Ordenações com a noção escolástica de razão natural, para concluir que a própria boa razão - ou a razão natural - é fonte subsidiária que serviria para suprir as lacunas não só do ordenamento nacional português, como para integrar as lacunas do próprio direito romano. No entanto, como informa BRAGA DA CRUZ, a maior parte dos autores tomava a expressão no sentido de que o bom senso tem primazia sobre a própria lei, "admitindo assim, implicitamente, a aplicação dos preceitos do direito romano, a título subsidiário, sem quaisquer reservas $(\ldots)^{89}$. Esta atitude implica na aceitação em bloco do direito romano, como expressão da ratio scripta ${ }^{90}$.

O terceiro ponto diz respeito ao critério de fixação da communis opinio. Acerca desta dúvida, formaram-se três correntes, oferecendo distintas soluções. A primeira delas, ligada à escolástica, pautava-se no critério meramente quantitativo, isto é, prevalecia, pura e simplesmente, a opinião expressada pela maioria dos autores. No breve período em que teve relevância, em Portugal, o humanismo jurídico, delineou-se uma corrente que primava pelo critério qualitativo. No entanto, reestabelecida a preeminência

\footnotetext{
${ }^{87}$ Neste sentido, Braga da CRUZ, op. cit. (nota 66), pág. 530; PousAdA, Estevan Lo Ré, op. cit. (nota 4), pág. 66. A própria Lei de 18 de agosto de 1769 (Lei da Boa Razão) indicava a ocorrência deste abuso em seu $\S 9^{\circ}$, cuja redação está transcrita infra, a partir da nota de rodapé $\mathrm{n}^{\circ} 101$.

${ }^{88}$ Ver, supra, 1.2.1, $2^{\circ}$.

${ }^{89}$ BRAGA DA CRUZ, Guilherme. $O$ direito subsidiário, op. cit. (nota 66), págs. 361-363.

${ }^{90}$ Neste sentido, ESTEVAn Lo RÉ PousADA: Se ela [a expressão boa razão] é utilizada em sua acepção de simples justificativa [da aplicação do direito romano como direito subsidiário], parecem estar certos os partidários da concepção do Corpus Iuris Civilis como encarnação (em bloco) da ratio scripta. Tal posição se justifica quando compreendemos a recepção do direito justinianeu como processo histórico, que tem seu ápice com a Carta Régia de 18 de abril de 1426 e vai buscar tão somente um título de legitimação na parte final do proêmio manuelino”. (PousAdA, Estevan Lo Ré. Preservação, op. cit. (nota 4), pág. 54). Sobre a Carta Régia de 18 de abril de 1426, remetemos o leitos à extensa nota sobre ela inserta por BRAGA DA CRUZ em seu $O$ direito subsidiário, op. cit. (nota 66), págs. 287-293. A controvérsia a respeito deste importante documento gira em torno de se saber se teria, por meio dele, D. João I determinado a aplicação do Código de Justiniano, da Glosa de Acúrsio e dos comentários de Bartolo - traduzidos para a língua portuguesa - como fontes imediatas ou como fontes subsidiárias ao direito nacional.
} 
da corrente escolástica, fixou-se uma posição mista, em que se mesclavam os critérios quantitativos e qualitativos: "a opinio communis seria, sem dúvida - nem de outro modo mereceria esse nome -, a opinião da maioria dos autores; mas duma maioria qualificada: da maioria do autores que tivessem versado ex professo o assunto em causa, analisando-se e discutindo-se, e não da maioria dos que simplesmente se lhes tivessem referido, louvando-se na opinião alheia ${ }^{91 "}$.

Entretanto, mesmo os autores que sustentavam, na teoria, o critério misto, acabavam, em suas obras, recheando suas páginas de citações, "sempre na preocupação de deslumbrar e convencer pelo exlusivo pelo do número, sem distinguirem entre as autoridades que tinha tratado o assunto ex professo e as que tinham limitado a reproduzir as opiniões de outrem; $(\ldots)^{92, \text {, }}$

Também nos tribunais a situação era parecida. Prevalecia o critério numérico que, no entanto, foi progressivamente substituído pela constante observação da prática dos tribunais superiores como expressão autorizada da communis opinio. Procurava-se, com isso, diminuir a incerteza e o arbítrio ${ }^{93}$.

Por fim, cumpre analisar a questão da interpretação restritiva ou extensiva do direito nacional quando em oposição ou conformidade, respectivamente, com o direito romano justinianeu.

Formou-se, ao longo dos anos, a prática de se interpretar as leis pátrias restritivamente, caso estabelecessem disciplina destoante do direito romano (odiosa limitanda, favorabilia amplianda), embora não houvesse qualquer regra expressa neste sentido. Tal prática foi atacada diretamente pela Lei da Boa Razão, em seu $§ 10^{\circ}$, como veremos infra.

Foi contra esse estado de coisas que as reformas empreendidas no reinado de D. José I, pelas mãos de Sebastião José de Carvalho e Melo, o Marquês de POMBAL, se voltaram. O despotismo esclarecido, tomando o ideário iluminista, procurou promover uma maior centralização jurídica, privilegiando o direito nacional em detrimento

\footnotetext{
${ }^{91}$ BRAGA DA CRUZ, Guilherme. O direito subsidiário, op. cit. (nota 66), págs. 367-369.

${ }^{92}$ Idem, Ibidem, págs. 373-375. No mesmo sentido, EsTEVAN Lo RÉ POUSADA: "No entanto este critério misto propugnado por muitos autores em suas obras de doutrina não era por eles próprio respeitado, sendo freqüentes nas mesmas obras as citações intermináveis, que tinham em vista o convencimento por meio da saturação". (Cit. (nota 4), pág. 57)

${ }_{93}$ Mais uma vez, estamos seguindo BRAGA DA CRUZ, Guilherme. O direito subsidiário, op. cit. (nota 66), págs. 376-378, e PousADA, Estevan Lo Ré. Preservação, op. cit. (nota 4), pág. 57.
} 
das fontes subsidiárias, já que, na prática, "quando se contempla a panorâmica geral da nossa jurisprudência, nos dois séculos e meio de vigência do esquema manuelino e filipino das fontes subsidiárias, o que domina amplamente é o uso e abuso do direito romano como ratio scripta e o uso e abuso da communis opinio - sintetizada particularmente na praxe dos altos tribunais - como critério da respectiva interpretação"94.

Desse modo, diante das distorções e abusos do sistema de direito subsidiário, tomaram-se duas importantes providências legislativas, inspiradas no programa introduzido em Portugal por LUís ANTÓNIO VERNEY: a primeira delas, a Lei de 18 de agosto de 1769, a Lei da Boa Razão; em seguida, complementando a reforma, vieram os Novos Estatutos da Universidade de Coimbra de 1772.

No âmbito do direito privado, regrado de forma geral pelo lacunoso Livro IV das Ordenações Filipinas, a reforma empreendida pela Lei da Boa Razão visando à reformulação da hierarquia das fontes de direito subsidiário, teria, por si só, impacto profundo $^{95}$. Não obstante, complementou-se a reforma com uma reestruturação dos estudos universitários que buscava a adequação da mentalidade dos juristas ao novo ideário político-filosófico. É o que passaremos a ver sem seguida.

\subsection{2 - As reformas pombalinas no sistema de fontes subsidiárias e no} ensino jurídico: a introdução do usus modernus pandectarum em Portugal.

\section{$\S 1^{\circ}$ - A Lei da Boa Razão, os Estatutos da Universidade de 1772 e o novo}

sistema de fontes subsidiárias $^{96}$. A Lei de 18 de agosto de 1769, designada por Lei da Boa Razão, provocou uma verdadeira revolução nos quadros do direito então vigente ${ }^{97}$.

\footnotetext{
94 BRAGA DA CRUZ, Guilherme, op. cit. (nota 66), págs. 379-380.

95 Neste sentido, BRAGA DA CRUZ: "Se a adaptação da letra expressa das Ordenações ou das leis extravagantes à nova linha de pensamento exigiu, como acabamos de ver, a introdução de importantes reformas legislativas, a tarefa tornou-se, porém, muito mais fácil, naquele vastíssimo domínio onde pontificavam, pela deficiência das leis nacionais, o recurso ao direito subsidiário, ou onde a atividade interpretativa era chamada a atuar, com ampla liberdade de movimentos. Aqui, para que tudo sofresse uma radical transformação, bastava que uma providência legislativa viesse impor novos critérios de interpretação e de integração das lacunas da lei, inspirados nas modernas correntes doutrinárias”. (BRAGA DA CRUZ, Guilherme. Formação, op. cit. (nota 15), pág. 42)

No mesmo sentido, MoreIRA Alves: "A Lei de 18 de agosto de 1769 (Lei da Boa-Razão) alterou as normas de emprego das fontes subsidiárias, e, por isso, exerceu decisiva influência no campo do direito privado, onde mais intensamente se fazia mister a integração de lacunas". (Cit. (nota 15), pág. 189)

96 A “alcunha" atribuída à lei (da Boa Razão) deve-se ao período liberal, especificamente à obra de JosÉ Homem CORREIA Telles, que cunhou a expressão Lei da Boa Razão em uma pequena nota preambular em
} 
Evidencia-se o objetivo da lei logo em seu preâmbulo: precaver "as interpretações abusivas; que offendem a magestade das Leis, desauthorisão a reputação dos Magistrados; e tem perplexa a justiça dos litigantes; de sorte que no direito, e domínio dos bens dos Vassallos não possa haver aquella provável certeza, que só póde conservar entre elles o publico socego:” Em seguida, expõe-se o problema da incerteza quanto ao direito causada por comentários excessivamente sutis a leis claras "e menos susceptíveis de intelligencias, que ordinariamente são oppostas ao espirito dellas (...)". Neste ponto, vê-se perfeita correspondência entre a palavra contida no preâmbulo da lei e o pensamento de LUÍS ANTÓNIO VERNEY ${ }^{98}$.

As providências impostas pela Lei têm eficácia tanto nas fontes nacionais, quanto nas fontes subsidiárias.

Em relação às fontes nacionais, nos oito primeiros parágrafos da Lei são tomadas medidas quanto à interpretação autêntica das leis, provocando uma verdadeira centralização do poder de proferir assentos na Casa da Suplicação de Lisboa, coibindo-se, ao mesmo tempo, a prática que se estabeleceu de se atribuir igual valor aos assentos dos

seu Comentário crítico à Lei da Boa Razão: "Huma das Leis mais notáveis do feliz Reinado do Senhor D. José, he a L. de 18 de Agosto de 1769. Denomino-a a Lei da BOA RAZÃo, porque refugou as Leis Romanas, que em BoA RAZÃo não forem fundadas". (Correia TElles, José Homem. Commentario critico á Lei da Boa Razão em data de 18 de agosto de 1769, Lisboa, Antonio José de Barros e Sá, 1824).

Como trabalho preparatório à elaboração dos novos Estatutos da Universidade, foi criada uma comissão, em 1770, denominada Junta da Providência Literária, para identificar as deficiências existentes no ensino superior e sugerir reformas. Já em 1771 é entregue o Compêndio Histórico do Estado da Univerisdade de Coimbra ao tempo da invasão dos denominados Jesuitas. No relatório, como fica evidente pelo próprio título, toda sorte de malefícios nos estudos é atribuída aos jesuítas.

Insurge-se o Compêndio histórico contra a prioridade que se dava aos estudos de direito romano em detrimento dos estudos da legislação nacional. Há, como há também em VERNEY, a exaltação do direito natural.

Na esteira do Compêndio, são promulgados os novos Estatutos logo no ano seguinte (1772)

Nas palavras de Nuno José EsPinosa Gomes Da Silva, "tal como em Vernei e no Compêndio Histórico, também nos Estatutos se encontram, pois, os habituais temas do pensamento setecentistas: exaltação do direito natural e das gentes, visão do direito romano através do 'usus modernus pandectarum', atenção concedida ao direito pátrio, apologia do método histórico e da síntese na investigação e exposição". (Cit. (nota 11), págs. 475-476).

${ }^{97}$ Cfr. BRAGA DA CRUZ, Guilherme. O direito subsidiário, op. cit. (nota 66), pág. 389.

${ }^{98}$ Em várias passagens da Carta XIII Verney se expressa no sentido de que as interpretações mais atrapalham o entendimento do direito do que o ajudam. "Confeso a V.P. que tendo visto, muitos comentadores dasInstituisoens, e alguns bem pouco conhecidos, neste Reino; nam vi algum, que se-pudese tolerar, e que nam disèse coizas indignas. Ou dizem coizas mal fundadas, ou se-metem a explicar coizas, que se-intendem melhor, quando nam se-explicam (...)" (pag. 167). Mais adiante, continua o autor: "Este é o defeito principal que eu acho, em todos os Jurisconsultos, falta de metodo. Nenhuma facilita a inteligência, das-coizas que trata (...)" (VERNEY, Luís António, op. cit. (nota 33) pág. 170). 
Tribunais da Relação do Porto Ultramarinos (Goa, Bahia e Rio de Janeiro), cujos assentos só passam a ter eficácia normativa após sua confirmação pela Casa da Suplicação ${ }^{99}$.

Ainda no que se refere às fontes nacionais, a Lei da Boa Razão, em seu $\S 14^{\circ}$, também tratou do costume de direito material, impondo três elementos para que houvesse norma jurídica consuetudinária: em primeiro lugar, deveria ser o costume centenário; em segundo lugar, ser conforme a boa razão; por fim, ser também conforme as Leis do Reino de Portugal ${ }^{100}$.

A prevalência da legislação pátria é ratificada pelo $\$ 11^{\circ}$ da Lei, em que se determina a não aplicabilidade - devidamente acompanhada das cominações de penalidades para os advogados que o invocassem - do critério odiosa limitanda, favorabilia amplianda, por meio de que se interpretava restritivamente o direito nacional quando em desconformidade em relação ao direito romano ${ }^{101}$.

O corolário do $\S 10^{\circ}$ é, justamente, a adoção da analogia como principal critério para o preenchimento de lacunas, prevalecendo este método sobre o recurso ao direito subsidiário, conforme disposição do $\$ 11^{\mathrm{o}}{ }^{102}$.

Em relação às fontes subsidiárias, uma importante medida foi estabelecida no $\S 12^{\circ}$ : determinou-se o afastamento da competência dos tribunais seculares de matéria envolvendo pecado. Com isso, fecha-se o ciclo do direito canônico na evolução do direito português $^{103}$.

${ }^{99}$ A respeito das alterações em relação à interpretação autêntica em relação à elaboração de cada tipo de assento, veja-se BRAGA DA CRUZ, Guilherme. O direito subsidiário, op. cit. (nota 66), notadamente nota de rodapé no 1 , pág. 391-397.

${ }^{100}$ Assim está redigido a disposição: "14. ITEM: (...) e que o costume deve ser sómente o que a mesma Lei qualifica nas palavras - longamente usado, e tal, que por direito se deva guardar: - cujas palavras mando; que sejão sempre entendidas no sentido de correrem copulativamente a favor do costume, de que se tratar, os trez essenciais requesitos: de ser conforme as mesmas boas razões, que deixo determinado que constituem o espirito de minhas leis: de não ser a ellas contrario em cousa alguma, e de ser tão antigo, que exceda o tempo de cem anos".

${ }^{101}$ Cfr. PousAda, Estevan Lo Ré. Preservação, op. cit., (nota 4), pág. 78.

A disposição está assim redigida: "11. ITEM: (...) E consideração do que tudo mando outro sim, que as referidas restricções, e ampliações extrahidas dos textos do Direito Civil, que atégora perturbarão as disposições das minhas Leis, e o socego publico dos meus Vassallos, fiquem inteiramente abolidas, para mais não serem allegadas pelos Advogados, debaixo das mesmas penas acima ordenadas, ou seguidas pelos Julgadores, debaixo da pena de suspensão de seus Officios até minha mercê, e das mais, que reservo o meu Real arbítrio".

${ }^{102} \mathrm{O} \S 11^{\circ}$ assim dispunha: "Exceptuo comtudo as restricções, e ampliações, que necessariamente se deduzirem do espirito das minhas Leis significado pelas palavras dellas tomadas no seu genuíno, e nautral sentido: as que se reduzirem aos principios acima declarados: e as que por identidade de razão, e por força de comprehensão, se acharem dentro no espirito das disposições das minhas ditas Leis (...)”.

103 “12. ITEM: (...) Mando outro sim, que a referida supposição d'qui em diante se haja por não escripta: declarando, como por esta declaro, que aos meus sobreditos Tribunaes, e Ministros Seculares não toca o 
Também foram proscritas, como fontes subsidiárias, a Glosa de ACÚRSIO e os comentários de BÁRTOLO, que, "durante mais de três séculos - com autonomia, ou limitadas pelas communis opinio -, tinham tido entre nós valor de fonte integradora de lacunas ${ }^{104}$.

Resta tratar do novo regramento que deu à hierarquia das fontes de direito subsidiário. O $\$ 9^{\circ}$ da Lei de 18 de agosto de 1769 dispõe sobre o método integração de lacunas do ordenamento, tema que, mais de perto, nos interessa. Desde logo fica claro que a intenção da Lei é inibir o desprezo que tinha das fontes de direito nacional em favor dos textos de direito romano e outros textos doutrinais ${ }^{105}$.

conhecimento dos peccados; mas sim, e tão sómente o dos delictos: e ordenando, como ordeno, que o referido conflicto fundado naquella erra supposição cesse inteiramente; deixando-se os referidos textos de Direito Canonico para os Ministros, e Consistorios Ecclesiasticos os observarem (nos seus devidos, e competentes termos) nas decisões da sua inspecção; e segundo sómente os meus Tribunaes, e Magistrados Seculares nas materias temporaes da sua competência as leis Patrias, e subsidiarias, e os louvaveis costumes e estylos legitimamente estabelecidos, na fórma que por esta Lei tenho determinado".

Destaca Nuno José EsPinOSA GOMES DA SILVA que "completava-se, nestes termos, o ciclo evolutivo do direito canónico na história das fontes do direito, no nosso país. Em 1211, o direito canónico sobrepunha-se ao próprio direito régio; agora, em 1769, deixa, sequer, de ter valor como fonte subsidiária". (Cit. (nota 11), pág. 468.

${ }^{104} \mathrm{O}$ afastamento dos indicados autores está contido no enunciado normativo do $\$ 13^{\circ}$ da Lei da Boa Razão: "13. ITEM: Sendo certo, e hoje de nenhum douto ignorado, que Accursio e Bartholo, cujas auctoridades mandou seguir a mesma Ord. no §1do sobredito tit., forão destituídos não só da instrucção da Historia Romana, sem a qual não podião bem entender os textos que fizerão os assumptos dos seus vastos escriptos; e não só do conhecimento da Philologia, e da bôa latinidade, em que fòrão concebidos os referidos textos; mas também das fundamentaes regras do Direito Natural, e Divino, que devião reger o espirito das Leis, sobre que escreverão:

E sendo igualmente certo, que ou para supprirem aquellas luzes, que lhes faltavão; ou porque na falta dellas ficarão os seus juízos vagos, errantes, e sem boas razões á que se contrahissem; vierão a introduzir na Jurisprudencia (cujo caracter formão a verdade, e a simplicidade) as quasi innumeraveis questões metaphysicas, com que depois daquella Escola Batholina se tem illaqueado, e confundido os direitos, e domínios dos litigantes intoleravelmente: mando que as glossas, e opiniões dos sobreditos Accursio, e Bartholo não possão mais ser allegadas em Juizo, nem seguidas na pratica dos Julgadores; e que antes muito pelo contrario em hum, e outro caso sejão sempre as bôas razões acima declaradas, e não as auctoridades daquelles, ou de outros, semelhantes Doutores da mesma Escola, as que hajão de decidir no fôro os casos occorrentes; revogando tambem nesta parte a mesma Ordenação, que o contrario determina".

${ }^{105}$ Eis a passagem do $\S 9^{\circ}$ : "9. ITEM: Sendo-me presente, que a Ordenação do Livro 3. ${ }^{\text {o }}$ titulo 64 no preambulo, que mandou julgar os casos omissos nas Leis Patrias, estylos da Côrte, e costumes do Reino, pelas leis que chamou Imperiaes, não obstante a restricção, e a limitação finaes do mesmo preambulo conteudas nas palavras - as quaes Leis Imperiaes mandamos somente guardar pela boa razão, em que são fundadas -, se tem tomado por pretexto; tanto para que nas allegações, e decisões se vão pondo em esquecimento as Leis Patrias, fazendo-se uzo sómente das dos romanos; como para se argumentar, e julgar pelas ditas Leis de Direito Civil geral, e indistinctamente, sem se fazer differença entre as que são fundadas naquella boa razão, que a sobredita Ordenação do Reino determinou por unico fundamento para as mandar seguir; e entre as que; ou tem visível incompatibilidade com a boa razão; ou não tem razão alguma, que possa sustentallas, ou tem por univas razões, não só os interesses dos differentes partidos, que nas revoluções da Republica, e do Imperio Romano, governarão o espírito dos seus Prudentes e Consultos, segundo as diversas facções, seitas, que seguirão; mas também tiverão por fundamentos outras razões assim de particuares costumes dos mesmo Romanos, que nada podem ter de communs com os das Nações, que presentemente habitão a Europa, como superstições proprias de Gentilidade dos mesmos Romanos, e inteiramente alheias da 
Habilmente, no entanto, o legislador procurou reduzir o problema a uma questão de correto entendimento do texto das Ordenações, que no Livro III, título LXIV, já dispunha que as leis romanas só seriam aplicadas "pola boa razão em que são fundadas".

Em seguida, em 1772, foi da Lei da Boa Razão complementada pelos Estatutos da Universidade. Neles, a ideia de coibir o abuso de se recorrer ao direito justinianeu foi complementada e especificada (L. 2, Tit. 2, cap. 3, $4^{\circ}$ ) concluindo CORREIA TELLES, com a integração dos dois textos, pela completa prevalência do direito nacional, devendo-se antes de tudo, recorrer-se à analogia do que ao direito romano, ainda que fundado este em boa razão ${ }^{106}$.

Para garantir a posição de prevalência do direito nacional, o $\S 9^{\circ}$ da Lei sob comento estipulava duas medidas: a) proibir qualquer utilização de textos ou de autoridades de alguns escritores caso existisse lei ou uso do Reino regrando a situação ${ }^{107}$; b) em seguida, a lei impõe como "supremo critério de integração" das lacunas do direito nacional a boa razão ${ }^{108}$.

Christandade dos séculos, que depois delles se seguirão (...)”.A transcrição continuará nas notas abaixo, conforme a pertinência ao corpo de texto.

106 ' $D$ ' aqui se colhe que as Leis Romanas tem authoridade extrínseca, nos casos omissos não só na letra, mas também no espirito das Leis Patrias, se acaso aquellas forem fundadas na boa razão. Os casos omissos na letra das Leis Patrias, mas comprehendidos no espirto-dellas, por identidade de razão, e por força de comprehensão; este devem julgar-se também pelas Parias, e não pelas Romanas, ainda que estar pareção fundadas em boa razão. He o que decide o §11. da nossa Lei (...)". (CorreiA Telles, José Homem. Commentario, op. cit. (nota 105), pág. 30)

A referida passagem dos Estatutos de 1772 é a seguinte: "O Direito Romano apenas póde obter força, e authoridade em Supplemento do Patrio, onde se não estendem as providencias das leis nacionaes, e quando he fundado na boa razão, que lhe serve de único fundamento. Assim foi mandado observar nestes Reinos desde a Legislação do Senhor D. João I nos sobreditos casos, que havião sido omittidos nas leis Patrias, e a que não se estendia ou a identidade de razão, ou o espirito das mesmas Leis Patrias. E neste mesmo verdadeiro sentido o tenho ordenado e estabelecido tambem da mesma sorte na Minha L. de 22 de Agosto de 1769, para reprimir os intoleráveis abusos, e excessos de authoridade, que nestes Reinos se dava ás ditas Leis Romanas em prejuizo das Leis Patrias: fixando os justos limites, e os certos casos, em que ellas podem ter ainda gluma authoridade, e o uso legitimo, que nos ditos casos se póde fazer ainda dellas nestes Reinos".

${ }^{107}$ Aqui está a disposição: "Mando por huma parte, que debaixo das penas ao diante declaradas se não possa fazer uso nas ditas allegações, e Decisões de Textos, ou de authoridades de alguns Escriptores, emquanto houver Ordenações do Reino, leis Patrias, e uzos dos meus Reinos legitimamente approvados tambem na forma abaixo declarada: (...)".

${ }^{108}$ A expressão entre aspas no texto é de BRAGA DA CRUZ, Guilherme. O direito subsidiário, op. cit. (nota 66), pág. 402.

Eis o enunciado normativo de que se trata: "E mando pela outra parte, que aquella boa razão, que o sobredito preambulo determinou, que fosse na praxe de julgar subsidiaria, não possa nunca ser a da authoridade extrínseca destes, ou daquelles textos do Direito Civil, ou abstractos, ou ainda com a concordancia de outros; mas sim, e tão sómente: ou aquella boa razão, que consiste nos primitivos principios, que contém verdades essenciaes, intrinsecas e inalteraveis, que a Ethica dos mesmo Romanos havia estabelecido, e que os Direitos Divino, e Natural, formalizarão para servirem de Regras Moraes, e Civis entre o Christiauismo: ou aquella boa razão, que se funda nas outras Regras, que de universal consentimento estabeleceo o Direito das Gentes para a direcção, e governo de todas as Nações civilisadas: ou aquella boa razão, que se estabelece nas leis Politicas, Economicas, Mercantis, e Maritimas; que as mesmas Nações Christãs tem promulgado com 
Em seguida, o texto normativo faz uma breve explicitação do que se deve entender por boa razão (veja-se a transcrição na nota de rodapé $n^{\circ} 112$ ): “(...) Vai o legislador pombalino permitir-se, ele próprio, o que o legislador das Ordenações não chegar a explicar, ou seja, o que deve se entender, para estes efeitos, pelo termo boa razão; e é então que aproveita o ensejo para , como soe dizer-se, 'encher de vinho novo os odres velhos', injectando nas encanecidas estruturas do direito português todo o pensamento racionalista e iluminista da escola do direito natural e do "usus modernus pandectarum". É, justamente, neste ponto, que reside “todo o carácter inovador - para não dizer revolucionário - da Lei de 18 de agosto de $1769^{109, "}$.

O direito romano, em si mesmo considerado, deixa de ser fonte de direito subsidiário para dar lugar, justamente, à boa razão ${ }^{110}$. Essa, por sua vez, deveria ser entendida em três vertentes: $a$ ) deveria entender-se boa razão como, nas palavras da Lei, o conjunto de "verdades essenciaes, extrínsecas e inalteraveis, que a Ethica dos mesmos Romanos havia estabelecido (...)"; tem-se aqui boa razão como equivalente a direito natural; $b$ ) deveria, ainda, ter-se por boa razão aquela contida "nas regras que de unanime consentimento estabeleceo o Direito das Gentes (...)”; c) por fim, dever-se-ia buscar a boa razão "nas Leis Politicas, Economicas, Mercantís e Maritimas, que as mesmas Nações Christãs tem promulgado com manifestas utilidades do soccego publico"; tem-se aqui, portanto, boa razão como direito positivo moderno ${ }^{111}$.

Esse último ponto tem vital relevância para a temática desenvolvida neste trabalho. Estamos a investigar o eventual influxo de ideias jusracionalistas no direito privado brasileiro por meio do direito comercial. E encontramos, justamente, na Lei da Boa Razão o dispositivo que determinava a aplicação da legislação estrangeira, muitas vezes expressão do pensamento jusracionalista (veja-se supra, Introdução, §3º em matéria mercantil.

No entanto, continua a Lei de 18 de agosto de 1769 aduzindo que é "muito mais racionavel, e muito mais choerente, que nestas interessantes materias se recorra,

manifestas utilidades, do socego publico, do estabelecimento da reputação e do augmento dos cabedaes dos povos, que com as disciplinas destas sabias, e proveitosas Leis vivem felices à sombra dos thronos, e debaixo dos auspicios dos seus respectivos monarcas, e Principes Soberanos".

${ }^{109}$ BRAGA DA CruZ, Guilherme. O direito subsidiário, op. cit. (nota 66), pág. 404.

${ }^{110}$ Cfr. BRAGA DA CRUZ, Guilherme. Formação, op. cit. (nota 15), pág. 43.

${ }^{111}$ Sobre as três diversas acepções de boa razão contidas na Lei de 18 de agosto de 1769, veja-se BRAGA DA CRUZ, Guilherme. O direito subsidiário, op. cit. (nota 66), págs. 405-406; também PousADA, Estevan Lo Ré. Preservação, op. cit. (nota 4), págs. 79-80, em nota de rodapé. 
antes, em caso de necessidade ao subsidio proximo das sobreditas Leis das Nações Christãs, illuminadas, e polidas (...) do que ir buscar sem boas razões, ou sem razão digna de attender-se, depois de mais de 17 seculos o socorro ás Leis de huns Gentios $(\ldots)^{112,}$.

Essa disposição foi entendida pelos intérpretes, a partir de então, como proibição de aplicação do direito romano nas matérias indicadas ${ }^{113}$, inclusive, portanto, no direito mercantil, que, pela deficiência da legislação em Portugal - e também no Brasil ficou quase que exclusivamente sujeito ao regramento da legislação estrangeira.

Em complemento à disposição da Lei da Boa Razão, vieram os Estatutos da Universidade de Coimbra de 1772 impor um critério de ordem prática para aferição do direito romano aplicável subsidiariamente, ou seja, um critério de identificação do direito romano em conformidade com a boa razão, para que pudesse ter aplicação imediata o disposto na Lei de 1769. O critério foi o do usus modernus pandectarum.

No Livro II, título V, Capítulo II, §§ 13 a 16 dos Estatutos de 1772 estabeleceu-se que não poderiam ser invocadas disposições de direito romano: a) de inspiração pagã; $b$ ) em desconformidade com a moral cristã; $c$ ) contrários às regras de direito natural e de direito das gentes; $d$ ) relativos a matérias políticas, econômicas, mercantis e marítimas. Ainda, para aplicação de tais regras, impunham os Estatutos que se recorresse aos autores europeus cujas obras eram expressão do uso moderno ${ }^{114}$.

${ }^{112}$ Está assim redigida a disposição: "Sendo muito mais racionavel, e muito mais coherente, que nestas interessantes materias se recorra antes em caso de necessidade ao subsidio proximo das sobreditas Leis da Nações Christãs, illuminadas, e polidas, que com ellas estão resplandecendo na boa, depurada e sã Jurisprudencia; em muitas outras erudições uteis, e necessárias; e na felicidade; do que ir buscar sem boas razões, ou sem razão digna de attender-se, depois de mais de 17 seculos o socorro ás Leis de huns Gentios; que nos seus principios Moraes, e Civis forão muitas vezes perturbados, e corrompidos na sobredita fórma; que do Direito Natural tiverão apenas as poucas e geraes noções, que manifestão os termos, com que o definirão; que o Direito Divino, he certo, que não souberão cousa alguma, e que o Commercio, da Navegação, da Arithimetica Politica, e da Economia de Estado, que hoje fazem tão importantes objectos dos Governos Supremos, não chegarão a ter o menor conhecimento".

${ }^{113}$ Crf. BRAGA DA CRUZ, Guilherme. O direito subsidiário, op. cit. (nota 66), págs. 407-408.

${ }^{114}$ Cfr. POUSADA, Estavan Lo Ré. Preservação, op. cit. (nota 4), págs. 81-82.

A seguir, transcrevem-se os parágrafos do capítulo II, título V, Livro II, dos Estatutos de 1772, mencionados no corpo de texto: “\$13. Explorarão $1^{\circ}$ : se as Leis Romanas, que dispõem sobre os casos omissos pelas leis Patrias, contém algum vestígio de superstição Ethnica, e Paganismo dos Romanos, ou involvem algumas relíquias de praticas, e maximas, que por qualquer modo sejão contrarias aos costumes, e á Moral dos Christãos.

§14. Explorarão $2^{\circ}$ : se são oppostas aos dictames da boa razão, depois desta bem discutida, qualificada, e informada pela declarações, ratificações do Direito Divino; depois de aperfeiçoada e illustrada pela moral Christã; e depois de bem depurada das falsas, e enganosas apparencias, e illusões, que na indagação das Leis Naturaes padecerão os Estoicos, e outros Filosofos, em cujos systemas beberão os jurisconsultos Romanos as primeiras maximas da equidade natural, que seguirão nas suas respostas; vindo consequentemente a participarem das mesmas illusões, e enganos, pelas terem derivado, deduzido da moral daquelles Gentios, 


\section{$\S 2^{\circ}$ - Posteriores desenvolvimentos empreendidos pelo individualismo}

crítico em Portugal. Ao tecer alguns breves comentários sobre a execução da Lei da Boa

Razão, BRAGA DA CRUZ faz duas observações interessantes: a primeira delas é a de que a

Lei não teve o condão de afastar instabilidade da jurisprudência e a chincana dos advogados, apenas deslocando-as das questões que gravitavam em torno da prioridade da communis opinio sobre ACÚRSIO ou BÁRTOLO, para o problema da concordância ou não dos preceitos do direito romano com a boa razão para fins de sua aplicação subsidiária ${ }^{115}$.

A segunda observação feita pelo autor é a de que a "Lei da Boa Razão acabou por ser vítima, ela própria, da mesma táctica de 'meter vinho novo em odres velhos' que o seu texto tinha adoptado em relação ao texto anterior das Ordenações ${ }^{116 ", .}$

Se, em 1769, o legislador pombalino fez uso da expressão "boa razão" para enxertar nas Ordenações a recta ratio jusracionalista, na segunda metade do século XIX,

que muitas vezes não atinarão com os verdadeiros dictames da razão, por lhes faltar a luz da verdadeira crença.

$\S 15$. Explorarão $3^{\circ}$ : se as mesmas Leis dos Romanos se oppõem ao direito das Gentes, ou este se considere em quanto natural, e na accepção mais propria delle; ou se tome na accepção de positivo, e nas differentes especies de Consuetudinario, ou de Pacticio. Porque onde por qualquer das referidas especies de direito das Gentes se achar recebido, e praticado pela maior parte das Nações civilisadas co contrario do que dispõem as Leis Romanas, cessará inteiramente a determinação destas, e prevalecerá sem hesitação o que se achar determinado, ou recebido pela pratica, e uso da maior parte das ditas Nações.

$\S 16$. Explorarão $4^{\mathrm{o}}$; se as disposições das mesmas Leis Romanas se encontrão com as das leis Politicas, Economicas, Mercantis, e Maritimas das referidas Nações. Porque tendo sido os artigos, que constituem os objectos das referidas especies de leis, muito mais cultivados, e mais bem regulados nos ultimos séculos pelas sobreditas Nações; por terem estas sobre cada hum delles muito maiores luzes, e conhecimentos muito mais amplos do que tiverão os Romanos; e os quaes em tudo o que diz respeito a Navegação, e ao Commercio, tiverão vistas muito curtas, e tendentes a fim muito diverso; fica sem controvérsia ser muito maior a proporção e analogia, que com a mesma legislação das nossas Leis, que respeita aos ditos objectos da Economia, do Commercio, da Navegação, do que he a proporção, e analogia, que com a mesma Legislação das nossas Leis tem as ditas Leis dos Jurisconsultos Romanos: sendo certo que estes até ignorarão, e desconhecerão inteiramente quasi todos os Pontos, e Artigos dos referidos objectos: e resultando daqui deverem os mesmo Consultos ceder inteiramente sobre elles ás sobreditas Nações, e semre preferidas para a decisão das causas, e negocios pertencentes aos ditos objectos as leis, que as mesmas Nações tem estabelecido sobre elles a todas, e quaesquer Leis respectivas aos mesmos objectos, que se possão achar no Corpo de Direito Romano".

${ }^{115}$ BRAGA DA CRUZ, Guilherme. O direito subsidiário, op. cit. (nota 66), pág. 423. Em nota de rodapé $\left(\mathrm{n}^{\circ} 2\right)$ que se inicia na página indicada, o autor transcreve um interessante documento, salvo melhor juízo, ainda hoje sem publicação - exceto a própria transcrição realizada por MARTIM DE ALBUQUERQUE, de que o próprio BRAGA DA CRUZ se utiliza -, que contem severa crítica ao estado caótico gerado pela Lei da Boa Razão. Trata-se do prefácio que formulou CORREIA TElLES ao seu Digesto Portuguez, que não foi publicado por ocasião da primeira edição da obra, conservando-se sob posse de MARTIM DE ALBUQUERQUE: "Depois da famosa L. de 18 de Agosto de 1769, que nova será de questões forenses, sobre a Lei Romana He ou não fundada na boa razão! E isto assim, por que o determinar as Longitudes no meio do Oceano não He mais dificil, do que o fixar as características da boa, e da má razão! Devemos confessar que as Leys Romanas contem doutrinas preciosas [...] mas o estudo dellas deve pertencer aos legisladores, para entre ellas, e as diversas interpretações dos Expositores escolherem o mais proveitoso. Deixadas ellas nas mãos dos Juizes e Advogados, com liberdade de julgarem e conselharem por ellas; os povos são victimas da priguiça do Legislador, arruinando-se com processos, que se terião evitado com Leis Nacionaes terminantes". (BRAGA DA CRUZ, Guilherme. Ibidem, pág. 424, em nota de rodapé)

${ }^{116}$ BRAGA DA CRUZ, Guilherme. Ibidem, pág. 427-428. 
os juristas portugueses passaram a se aproveitar da disposição da Lei da Boa Razão, complementada pelos Estatutos da Universidade, para preferir, como fonte subsidiária, não mais o direito romano conforme o usus modernus, mas o direito das modernas codificações européias, já embebidas do individualismo de inspiração francesa. As principais fontes subsidiárias passaram a ser o articulado do Código Civil francês, os Códigos da Prússia, da Sardenha ou da Áustria ${ }^{117}$.

Informa BRAGA DA CRUZ que, já em 1820, o Código Civil francês começa a ser invocado na obra de MANuel de Almeida e SouZA (DE LoBÃo). No entanto, é José HOMEM CORREIA TELLES quem amplia a utilização do Code de 1804, quando publica o Digesto português, em $1835^{118}$.

No breve prefácio de sua obra, CORREIA TELlES destaca que se utilizou de obras legislativas estrangeiras, acrescentando não haver nisso qualquer novidade. Chama atenção o fato de o autor não se preocupar em justificar o porquê de se utilizar dos diplomas estrangeiros ${ }^{119}$.

Observando a obra de COELHO DA ROCHA, BRAGA DA CRUZ conclui que o argumento utilizado para justificar a troca do direito romano pelos códigos modernos pode ser tido como ingênuo e simplista: Com efeito, "se os Estatutos da Universidade, em esclarecimento da Lei da Boa Razão - dirá ingenuamente COELHO DA ROCHA -, permitem 'averiguar o uso moderno das nações nos escriptos dos seus Jurisconsultos, por maioria de razão deve [esse uso moderno] ser procurado nas suas leis" ",120.

\section{$\S^{\circ}$ - Consequências da nova metodologia de integração de lacunas no}

direito privado português e brasileiro. Seja qual for a justificativa para a utilização dos códigos estrangeiros, é importante notar que o recurso constante à legislação estrangeira provocou uma guinada na evolução do direito privado português. A nova metodologia de

\footnotetext{
117 Idem, Ibidem, págs. 428-429. Pode-se caracterizar, em linhas muito amplas, apenas para fins de contextualização, o individualismo como um movimento de reação ao "déspota esclarecido". A revolução de 1789 inicia um período de desconfiança em relação ao poder estatal, colocando-se em relevo, ao contrário do período anterior, os direitos do indivíduo que precedem à própria sociedade política. Para uma visão panorâmica das características do período, veja-se GoMES DA SILVA, Nuno José Espinosa. História, op. cit. (nota 11), págs. 489-494.

${ }_{118}$ Braga DA CRUZ, Guilherme. $O$ direito subsidiário, op. cit. (nota 66), pág. 431-432.

119 "Em apoiar muitos artigos sobre disposições de Codigos estranhos, tambem não introduzi novidade". (CORReIA Telles, José Homem. Digesto portuguez ou tratado dos direitos e obrigações civis accomodado ás leis e costumes da nação portugueza para servir de subsidio ao novo codigo civil, tomo I, Coimbra, Imprensa da Universidade, 1835, pág. 5)

${ }^{120}$ BRAGA DA CRUZ, Guilherme. O direito subsidiário, op. cit. (nota 66), pág. 433.
} 
integração de lacunas inaugurada pela nova interpretação que se deu ao $\S 9^{\circ}$ da Lei da Boa Razão, complementado pelos Estatutos da Universidade de 1772, pelo liberalismo crítico, permitiu que uma série de inovações contidas nos monumentos legislativos estrangeiros como o próprio Code Civil - penetrassem no ordenamento português, alterando de forma significativa suas feições, especialmente no que toca ao direito privado.

Veja-se, por exemplo, na já mencionada obra de CORREIA TELles, o Digesto portuguez. Ao tratar do contrato de compra e venda, no art. 182, o autor enuncia o seguinte: “Adquirimos a propriedade das cousas, eis que o vendedor convem em ceder a sua cousa pelo certo preço, que o comprador promette dar-lhe ${ }^{121}$ ". Ao atribuir eficácia real ao contrato de compra e venda, o autor rompia com a tradição oriunda do direito romano de separação entre título e modo de aquisição, filiando-se à doutrina do art. 1583 do Code Civil de 1804, segundo a qual o mero consentimento opera eficácia real, sem necessidade de qualquer outro ato para a transferência da propriedade.

Já vimos acima (Introdução, $\S 5^{\circ}$ ) que o direito civil brasileiro escapou, de forma geral, da penetração dessas novas ideias por razões que podem ser localizadas tanto na história jurídica externa, quando na história social do país.

${ }^{121}$ Correia Telles, José Homem. Digesto, op. cit. (nota 119), tomo III, pág. 33. É interessante notar que, em nota ao artigo, CORREIA TELLES invoca como justificativa do preceito as Institutas de Justiniano (Livro III, título XXIII, De emptione et venditione), bem como as Ordenações Filipinas (Livro 4, Tit. II). Interessante notar que, escrevendo alguns anos mais tarde, FELício DOS SANTOS, em seu Projecto de Codigo Civil e commentario, redigia o art. 1877 de forma semelhante ao de CORREIA TELLES: "Nos contractos, que têm por objecto a transferencia da propriedade, ou de um outro direito sobre cousa movel ou immovel, a transferência da propriedade, ou do direito opera-se entre os contratantes e seus herdeiros, por mero effeito do contrato, sem dependencia de tradição ou posse, quer material, quer simbolica, e desde esse momento o perigo da cousa corre por conta do adquirente".

A favor de seu posicionamento, o autor invocava, como CoRreiA Telles, a Ord. L.4, tit. 2: "Fazendo-se compra e venda de alguma cousa por certo preço, depois que o contracto he acordado e firmado pelas partes, não se póde mais alguma dellas arrepender sem consentimento da outra. Porque, tanto que o comprador e o vendedor são acordados na compra e venda de alguma certa cousa por certo preço, logo esse contracto he perfeito e acabado, em tanto que dando, ou offe(r)ecendo o comprador ao vendedor o dito preço, que seja seu, será elle obrigado de lhe entregar cousa vendida, se fôr em seu poder; e se em seu poder não fôr, pagarlhe-há todo o interesse, que lhe pertencer, assi por respeito do ganho, como por respeito da perda”. FELício DOS SANTOS, além de invocar a Ord. L.4, tit. 2, teve o cuidado de argumentar não ser a Ord. L. 4, Tit. 7 definitiva em relação à diferenciação entre título e modo de aquisição. Dispunha a Ord. L. 4, Tit. 7: "Se o que fôr senhor de alguma cousa, a vender duas vezes a desvairadas pessoas, o que primeiro houver a entrega della será della feito verdadeiro senhor, se della pagou o preço, por que lhe foi vendida, ou se se houve o vendedor por pago della, porque concorrendo assi na dita venda entrega da cousa e paga o preço, o fazem ser senhor della”.

No Brasil, como cediço, não prevaleceu a eficácia real da compra e venda, conservando-se a diferenciação entre título e modo de aquisição. Sobre tal assunto, remetemos à obra de AUGUSTO TEIXEIRA DE FREITAS, especialmente a Introdução às sua Consolidação das Leis Civil (TEIXEIRA DE FrEITAS, Augusto. Consolidação, op. cit. (nota 20). Sobre este específico aspecto da obra do grande jurisconsulto brasileiro, veja-se PousADA, Estevan Lo Ré. Preservação, op. cit. (nota 4), notadamente o capítulo 3. 
Em relação à história externa, pode-se aduzir, com BRAGA DA Cruz, que "nas primeiras décadas após a independência e de liberalismo, não houve reformas legislativas com tão amplos reflexos jurídico-privados como as que, em Portugal, na mesma época, se levaram a cabo ${ }^{122 \%}$. Com isso, pôde vigir entre nós as Ordenações Filipinas, compilação que é, ainda, expressão do direito medieval. Esse fato, sem duvida, como bem observa ORLANDO GOMES, singulariza a história do direito civil brasileiro ${ }^{123}$.

No que toca à história social, nota-se que, mesmo após a independência, não houve uma significativa mudança na estrutura social do país a ponto de ensejar a necessidade de uma legislação mais avançada e moderna. Tanto assim, que já em começos do século XX nossa legislação de direito privado ainda eram as Ordenações de 1603 embora renovadas pelos influxos jusracionalistas da Lei da Boa Razão e dos Estatutos da Universidade de $1772^{124}$.

No entanto, a despeito de o direito civil ter se mantido fiel à tradição jurídica lusitana, o direito comercial sofreu uma maior influência da metodologia de integração de lacunas do individualismo crítico, além de ter florescido em ambiente social diverso daquele da aristocracia agrária. É o que passaremos a ver no capítulo seguinte.

\footnotetext{
${ }^{122}$ Braga DA CRUZ, Guilherme. Formação, op. cit. (nota 15), pág. 66.

${ }^{123}$ GoMES, Orlando. Raízes, op. cit. (nota 15), pág. 3. Veja-se, ainda, supra, nota de rodapé no 15.

${ }^{124}$ Neste sentido, GoMES, Orlando. Ibidem, págs. 14-31; PONTES DE MIRANDA, Francisco Cavalcanti. Fontes e evolução, op. cit. (nota 15), págs. 6-7; ainda, OliVEIRA VIANNA, Francisco José. Institiuções políticas brasileiras, $2^{\text {a }}$ ed., vol. I, Rio de Janeiro, José Olympio, 1955, págs. 323-324.

No capítulo seguinte, veremos como, após a abertura dos portos, houve a criação de uma classe mercadora diferenciada da elite agrária e política, a despeito da comunhão de interesses com ela. Essa nova classe, certamente, contribuiu para que o direito comercial brasileiro se afastasse, ainda que de forma tímida, da orientação conservadora que seguiu o direito civil nacional.
} 


\section{Capítulo 2 - Os primeiros passos do Direito Comercial brasileiro: a abertura dos portos, a ascensão de uma nova elite e a aplicacão da legislacão estrangeira no Brasil.}

Plano do capítulo - O presente capítulo pretende analisar o itinerário percorrido pelo direito mercantil brasileiro desde o advento da abertura dos portos até sua codificação, concluída com a promulgação do Código Comercial de 1850.

Pretendemos destacar, ao longo da exposição, o importante papel exercido pela legislação estrangeira em matéria mercantil. Como tivemos oportunidade de observar na introdução (supra, $\S 6^{\circ}$ ), durante considerável lapso temporal aplicaram-se no Brasil os monumentos legislativos mercantis estrangeiros, notadamente o Código de Comércio francês, de 1807, o Código Comercial espanhol, de 1829 e o Código Comercial português, de 1833, em vista da deficiência da legislação mercantil nacional. Tal fato, permitido pelo $\S 9^{\circ}$ da Lei da Boa Razão combinado com as disposições pertinentes nos Estatutos da Universidade de Coimbra de 1772 (L. II, tit. V, cap. II, §§ 13 a 16), permitiu o influxo, em nosso direito privado, de inovações do período Iluminista, fazendo com que nosso direito mercantil fosse menos conservador que o direito civil.

Some-se a isso o dado de que um dos nossos juristas formadores do direito comercial nacional, José dA Silva LisboA, o Visconde DE CAIRU, ter realizado seus estudos superiores na Universidade de Coimbra recém reformada pelos novos Estatutos, estando, certamente, embebido no espírito do usus modernus propugnado pela reforma pombalina.

Verificaremos, além disso, um aspecto da história social do país: a formação de uma classe comerciante com diferenciações internas. Embora tivesse essa classe nascente interesses em comum com aqueles da aristocracia agrária, nota-se que seu modo de vida, essencialmente urbano, e seus valores, essencialmente burgueses, contrastam com os daquela velha classe dominante. No jogo de interesses políticos, os comerciantes, especialmente aqueles da praça do Rio de Janeiro, teriam influenciado decisivamente os traços do Código de 1850.

Por fim, analisaremos o processo de codificação do direito mercantil. Evidenciar-se-á o importante papel dos comerciantes nesse processo, uma vez que a 
comissão responsável pelo projeto primitivo era composta, justamente, por membros dessa classe. Além de que, diversas das emendas ao projeto e projetos substitutivos foram encaminhados por órgãos de classe dos mercadores.

Ao final, pretender-se-á ter demonstrado por que meios a história do direito comercial brasileiro se diferencia daquela do direito civil, na medida em que cedeu mais espaço a inovações, seguindo, em certas matérias, caminho oposto daquele seguido pelo direito civil nacional, como veremos no capítulo 3.

\section{1 - A abertura dos portos e sua influência no direito comercial brasileiro}

\subsection{1 - Antecedentes da abertura.}

$\$ 1^{0}$ - Portugal e Brasil entre Inglaterra e França. Quando o General Junot e seus comandados cruzaram a fronteira entre Espanha e Portugal, adentrando a província do Alentejo, um golpe mortal foi desferido contra o já cambaleante sistema colonial lusobrasileiro.

Não se compreende, no entanto, a invasão e suas consequências sem um breve panorama dos eventos que a antecederam. Tais eventos foram atos de uma guerra travada entre França e Inglaterra em que Portugal figurou, apenas, como uma peça no tabuleiro europeu, empurrado ora ao mar, ora ao continente, pelas forças das potências beligerantes.

Todavia, apesar de sua atuação como coadjuvante no concerto europeu, Portugal sofreu consequências significativas, podendo-se apontar, em última instância, a transferência da corte para o Brasil, a abertura dos portos brasileiros à navegação e ao comércio das nações amigas e o início do processo de independência da colônia em relação à metrópole.

$\$ 2^{\circ}$ - O conflito franco-britânico. Observou-se, nos últimos anos, particular interesse pelo período compreendido entre os anos de 1807 e 1808 por conta do 
bicentenário da transferência da família real portuguesa para o Brasil e a abertura dos portos da então colônia para o comércio.

Muitas obras foram editadas por ocasião das comemorações ${ }^{125}$. Entre elas destacou-se o livro do jornalista LAURENTINO GOMES, cujo título é, simplesmente, 1808, mas cujo subtítulo pode ser considerado polêmico: “como uma rainha louca, um príncipe medroso e uma corte corrupta enganaram Napoleão e mudaram a História de Portugal e do Brasil ${ }^{126}$.

A simplicidade dos termos utilizados pelo autor - louca, medroso, corrupta - não tem o condão de explicitar com precisão a natureza dos eventos que culminaram com a vinda da corte para o Brasil que, bem pelo contrário do que é sugerido, foram, com efeito, muito complexos.

O equilíbrio de forças na Europa, em si mesmo, já estava dotado de alguma dose de complexidade. Por um lado, a França, comandada por Napoleão, visava "conquistar o mar pelo poder da terra", impondo o Bloqueio Continental (1806) para impedir que produtos ingleses penetrassem no continente. Este conjunto de medidas resultaria no fechamento definitivo das três únicas vias de acesso das mercadorias inglesas, quais fossem, os portos suecos, dinamarqueses e portugueses. Caso obtivesse sucesso nesta empresa militar, a França teria, ainda, uma vantagem adicional: além de provocar o esmorecimento do comércio oficial da Inglaterra com as nações continentais, seria possível o aprisionamento das marinhas de guerra daqueles três países, compensando, em alguma medida, as perdas sofridas pela marinha francesa para a Inglaterra na batalha de Trafalgar $^{127}$.

A Inglaterra, por sua vez, procurava "conquistar a terra pelo poder do mar". Antecipando-se às medidas do bloqueio, os britânicos atacaram Copenhague e tomaram posse da marinha dinamarquesa, eliminando, com isso, um dos fortes pilares da estratégia de Napoleão.

${ }^{125}$ Para um panorama da recente bibliografia sobre o período mencionado, ver LoPES, Walter de Mattos. A Real Junta de Commercio, Agricultura, Fábricas e Navegação deste Estado do Brazil e seus domínios ultramarinos: um tribunal de antigo regime na corte de Dom João (1808-1821), dissertação, Niterói (UFF), 2009, especialmente págs. 15-19.

126 GOMES, Laurentino. 1808: como uma rainha louca, um príncipe medroso e e uma corte corrupta enganaram Napoleão e mudaram a história de Portugal e do Brasil, $2^{\mathrm{a}}$ ed., São Paulo, Planeta, 2007.

127 ARRUDA, José Jobson de Andrade. Uma colônia entre dois impérios: a abertura dos portos brasileiros (1800-1808), Bauru, EDUSC, 2008, págs. 19-20. 
Portugal - além de ser um velho aliado inglês desde o século XVII ${ }^{128}$ - era excepcionalmente importante para a Inglaterra naquele período, pois, além de ser uma das portas de entrada dos produtos britânicos para a Europa continental, supria, também, as fábricas inglesas de matéria-prima com a reexportação do algodão brasileiro. $\mathrm{O}$ algodão reexportado por Portugal para a Inglaterra assumia papel tão essencial que, pela primeira vez na história, a balança comercial entre o dois países pendia para o lado português. A Inglaterra necessitava, para continuidade de sua expansão industrial e escoamento de sua produção, de uma marinha forte, o que, por sua vez, demandava crescentes investimentos públicos. Por essa razão, o influxo de ouro para a Inglaterra era essencial, e uma balança de comércio positiva, necessária. Assim, uma vez verificada a inversão da balança com Portugal, o governo inglês passou a diligenciar para conseguir o comércio direto com a colônia (Brasil), possibilitando livrar-se do entreposto lisboeta.

Após o bombardeio a Copenhague, Portugal passa a também ser o foco das atenções da França de Napoleão.

A diplomacia portuguesa, em meio ao crescente conflito entre as duas grandes potências, teve de adotar a postura de rejeição a qualquer manifestação partidária, visando, justamente, à sobrevivência nacional. Com isso, a política externa portuguesa “tornou-se dúplice em sua essência, incerta em seus objetivos e pusilâmine em seus métodos $^{129,}$.

Os exemplos dos sucessos militares obtidos por Napoleão mostravam às nações européias que não havia alternativa para sua subsistência que não a "abjeta docilidade" frente às exigências dos franceses: "todas as nações que haviam se erguido em armas contra a França tinham sido vencidas $(\ldots)^{130,}$.

Assim, diante deste quadro, o Regente D. João procurava manter-se equidistante das forças beligerantes.

\footnotetext{
${ }^{128}$ ALAN K. MANCHESTER informa que a Inglaterra conquistou influência dominante sobre Portugal a partir da assinatura de três tratados complementares, assinados, respectivamente, em 1642, 1654 e 1661 (British preeminence in Brazil - its rise and decline: an study in european expansion, Chapel Hill, The University of North Carolina Press, 1933, pág. 1)

${ }^{129}$ FreITAS, Caio de. George Canning e o Brasil: influência da diplomacia inglesa na formação brasileira, vol. I, São Paulo, Cia. Editora Nacional, 1958, pág. 55.

${ }^{130}$ Idem, Ibidem, pág. 56.
} 
$\$ 3^{\circ}$ - A Convenção Secreta de Londres (22 de outubro de 1807). A

Dinamarca, como Portugal, declarava-se nação neutra no conflito franco-britânico e, mesmo assim, teve sua capital bombardeada por navios ingleses ao longo de três dias, enquanto boa parte de seu exército se dirigia ao sul do país para conter tropas napoleônicas, o que ia ao encontro dos interesses da própria Inglaterra. $\mathrm{O}$ ataque a Copenhague era, certamente, uma imagem ameaçadora posta diante de Portugal, tanto que, aos 22 de outubro de 1807 - um dia após a marinha britânica zarpar da Dinamarca de volta às ilhas com a posse da esquadra do país neutro -, era assinada, em Londres, a Convenção Secreta entre Portugal e Inglaterra ${ }^{131}$.

O documento assinado pelo plenipotenciário português na Inglaterra, Domingos de Sousa Coutinho, continha uma série de concessões impostas pelos ingleses, explorando o temor português em relação à sua própria sobrevivência enquanto nação soberana.

A convenção foi escrita em nove artigos e o enunciado normativo do primeiro deles dispunha que o governo britânico não ocuparia a ilha da Madeira ou qualquer outra possessão portuguesa, mas, logo em seguida, no artigo terceiro, reserva-se o direito de ocupar a referida ilha "no caso infeliz" de o Príncipe Regente ter de fechar os portos de Portugal às embarcações inglesas ${ }^{132}$.

O artigo segundo dispunha sobre o auxílio a ser prestado pelo governo inglês caso o Príncipe Regente de Portugal se visse obrigado a transladar a corte para o Brasil. Nesta situação, a marinha britânica disponibilizaria uma esquadra de seis naus de

\footnotetext{
131 ARrudA, José Jobson de Andrade, op. cit. (nota 127), págs. 20-23. CAIO DE FreITAS destaca que a assinatura da Convenção Secreta não foi um ato isolado, mas uma "ação paralela ao aprisionamento da esquadra dinamarquesa", um ato em conjunto maior de medidas arquitetas pela política externa britânica "concebidas e executadas que foram ambas sob a mesma ansiedade de agir, por antecipação, contra Bonaparte, tendo em vista a sua manobra de estrangulamento econômico das Ilhas Britânicas". (Cit. (nota 129), págs. 52-53)

${ }^{132}$ Os referidos artigos foram assim redigidos: "Art. I: [...] nenhuma expedição será feita pelo Governo Britânico contra a ilha da madeira nem contra qualquer possessão portuguesa. (...) Art. III: Mas, no caso infeliz em que o Príncipe Regente se visse obrigado a fechar os portos de Portugal às embarcações inglesas, o Príncipe Regente consente que as tropas inglesas sejam admitidas na ilha da Madeira [...], que a ilha será guardada em depósito para Sua Alteza Real o Príncipe Regente até a conclusão da paz definitiva entre a GrãBretanha e a França". O tratado encontra-se parcialmente transcrito na já citada obra de ARRUDA, José Jobson de Andrade, op. cit. (nota 127), págs. 144-146. O documento encontra-se disponível em reprodução digital no sítio do Arquivo da Torre do Tombo, cujo endereço para acesso é http://antt.dgarq.gov.pt/ <último acesso aos 27 de dezembro de 2011>.
} 
linha e um exército de cinco mil homens para escoltar a Família Real portuguesa para a América $^{133}$.

O governo português comprometia-se, ainda, a jamais entregar ou reunir a sua esquadra de guerra e mercante às da França, Espanha ou de qualquer outra potência européia, devendo, em caso de partida ao Brasil, levar consigo a frota ou entregar à Inglaterra, por depósito, a parte que não pudesse levar ${ }^{134}$.

Em contrapartida, a Inglaterra comprometia-se a combater eventuais invasores do território português, reconhecendo os representantes e herdeiros da casa de Bragança como os únicos legitimados ao trono do reino ${ }^{135}$.

Por fim, comprometiam-se as partes a tratar de um acordo de auxílio e comércio tão logo a corte portuguesa estivesse estabelecida no Brasil ${ }^{136}$.

Na mesma data da assinatura da convenção secreta, foram elaborados dois artigos adicionais. No primeiro deles - que não foi ratificado em Portugal -, comprometiase o governo português a, em caso de fechamento dos portos aos navios ingleses, ceder um porto na ilha de Santa Catarina ou em qualquer outro lugar da costa do Brasil, para livre escoamento de mercadorias inglesas pelo território brasileiro ${ }^{137}$.

${ }^{133}$ Eis a redação do art. II: "No caso em que Sua Alteza Real o Príncipe Regente se visse obrigado [...] de passar ao Brasil, [...] estará pronto Sua Majestade Britânica a ajudá-lo nesta empresa, a proteger o embarque da Família Real e a escoltá-los à América [...], aprestar imediatamente nos portos de Inglaterra uma esquadra de seis naus de linha [...] e de ter neles igualmente, pronto a embarcar-se, um exército de cinco mil homens". Transcrição conforme ARRUDA, José Jobson de Andrade, op. cit. (nota 127), págs. 144.

134 “Art. IV: [...] jamais ceder, em caso algum, seja no todo seja em parte, a sua marinha militar ou mercante ou de as reunir às da França ou de Espanha ou de outra qualquer potência. [...] Transferir como depósito para a Grã-Bretanha aquela parte que não puder levar imediatamente consigo". Transcrição conforme ARRUDA, José Jobson de Andrade, op. cit. (nota 127), págs. 144.

135 "Art. V: No caso de clausura dos portos de Portugal, obriga-se Sua Alteza Real a mandar sair incessantemente para o Brasil metade da sua marinha de guerra e a conservar a outra metade em número pouco mais ou menos de cinco ou seis naus de linha e de oito ou dez fragatas, em meio armamento (pelo menos), no porto de Lisboa, de sorte que, à primeira indicação hostil da parte dos franceses ou espanhóis, aquela força naval possa reunir-se à esquadra, [...] a oficiais cujos princípios políticos sejam aprovados na Grã-Bretanha”. Transcrição conforme ARRUDA, José Jobson de Andrade, op. cit. (nota 127), págs. 144-145. “Art. VI: A guarnição da Monarquia Portuguesa estando estabilizada no Brasil, Sua Majestade Britânica se compromete, em Seu Nome e naquele de Seus Sucessores, a jamais reconhecer como Rei de Portugal qualquer príncipe que não seja Herdeiro ou Representante legítimo da Casa Real de Bragança; (...)”. Para a transcrição do art. VI não pudemos manter o padrão de utilizar a tradução contida na obra de JOSÉ JOBSON DE ANDRADE ARRUDA, pois na obra citada falta este artigo. Consultamos a versão digitalizada no sítio do Arquivo da Torre do Tombo (nota 144), realizando tradução livre a partir do original francês.

136 “Art. VII: Quando o Governo Português estiver estabelecido no Brasil, proceder-se-á à negociação de um tratado de auxílio e de comércio entre o Governo Português e a Grã-Bretanha”.

137 "Ato adicional, art. I: No caso da clausura dos portos de Portugal à bandeira inglesa, será estabelecido um porto na ilha de Santa Catarina ou em qualquer outro lugar da costa do Brasil, onde todas as mercadorias inglesas, que ao presente são admitidas em Portugal, serão importunadas livremente em embarcações inglesas, pagando os mesmo direitos que se pagam atualmente pelos mesmos artigos nos portos de Portugal, 
O segundo artigo adicional determinava a suspensão dos tratados firmados entre a Grã-Bretanha e o Portugal enquanto durasse o fechamento dos portos aos navios ingleses ${ }^{138}$.

$\$_{4^{\circ}}$ - Interesses ingleses por trás da Convenção Secreta. A transferência da corte portuguesa para o Brasil não era, em 1807, uma ideia nova, tanto por parte da Inglaterra, quanto por parte de Portugal. Certamente, a própria existência da Convenção Secreta mitiga qualquer intenção de julgar como "fuga" a transferência da corte portuguesa para o Brasil em 1808.

Nesse momento histórico, contudo, em vista da tentativa de estrangulamento econômico promovida pela França contra a Inglaterra, a migração da família real tornavase um imperativo da política externa inglesa em vista dos interesses dos exportadores britânicos, impulsionados agora pela Revolução Industrial.

George Canning, o homem a frente do Foreign Office entre os anos de 1807 e 1809, foi o primeiro líder das relações internacionais inglesas a priorizar os interesses comerciais do seu país, orientando a diplomacia inglesa de acordo com as necessidades da expansão industrial que estava proporcionando à Inglaterra uma prosperidade jamais vista. Justamente por essa razão - a expansão da indústria combinada com a necessidade de mercados consumidores para escoamento da produção -, a estratégia elaborada para aprisionamento da frota dinamarquesa não seria a medida mais adequada para lidar com Portugal, pois, além de políticos e militares, estavam em jogo, sobretudo, interesses econômicos.

Antes mesmo do secretariado de Canning, a fundação de um império português no Brasil já era um firme intento britânico, ao ponto de se chegar a formular, entre os anos de 1805 e 1806, um projeto secreto com vistas à invasão do território

e este arranjamento durará até novo acordo". Transcrição conforme ARRUDA, José Jobson de Andrade, op. cit. (nota 127), págs. 145.

138 "Ato adicional, art. II: Fica plenamente entendido e ajustado que desde o momento em que os portos de Portugal forem fechados à bandeira inglesa, e por todo o tempo que assim contnuem, os tratados existentes entre a Grã-Bretanha e Portugal devem considerar-se como suspensos, pois que concedem à bandeira portuguesa privilégios e isenções de que as outras nações neutrais não gozam e que, segundo o direito das gentes, não pertencem ao estado de simples neutralidade". Transcrição conforme ARRUDA, José Jobson de Andrade, op. cit. (nota 127), págs. 146. 
brasileiro independentemente do consentimento de Portugal, caso a metrópole fosse dominada pela França ${ }^{139}$.

No julgamento de CAIO DE FREITAS, a transferência da corte para o Brasil, tão fomentada pela Inglaterra, a ponto de se explorar a neutralidade portuguesa a fim de conseguir um acordo diplomático garantindo a ocorrência deste evento, independia de qualquer justificativa de ordem política e militar, pois "iria proporcionar aos exportadores ingleses um contacto mais direto com o Brasil, eliminada que seria, em consequência dela, a existência do complicado entreposto de Lisboa ${ }^{140 ", ~}$

\section{$\$ 5^{\circ}$ - Fechamento dos portos portugueses à navegação inglesa. No mesmo}

dia em que, em Londres, era assinada a Convenção Secreta (22 de outubro de 1807), o governo português, cedendo às pressões militares napoleônicas, determinava o fechamento de seus portos aos navios ingleses.

Temia-se, no entanto, que este ato pudesse acarretar uma violenta reação militar britânica, como ocorrera com a Dinamarca. Por tal razão, Antônio de Araújo foi instruído pelo Príncipe Regente a explicar ao governo inglês que o documento de fechamento "não expressava qualquer intenção hostil em relação à Grã-Bretanha" e que "não era, e nem deveria ser considerado, como uma declaração de guerra ${ }^{141}$ ".

\footnotetext{
${ }^{139}$ ARRUDA, José Jobson de Andrade, op. cit. (nota 127), págs. 32-35. O projeto inglês descia aos mínimos detalhes. Se Portugal, invadido pela França, aceitasse a ajuda inglesa, havia duas expedições programadas: uma que rumaria diretamente para o Rio de Janeiro, e outra para Lisboa, para resgatar a família Real. Caso o governo português recusasse a ajuda inglesa, as forças britânicas rumariam para a conquista do porto de Salvador, a partir de que seriam organizados ataques aos portos de Buenos Aires, Lima e Caracas, tidos como essenciais para o escoamento de mercadorias inglesas.

Deve-se observar, no entanto, que CARLos GuILHERME Mota aponta que teria sido Dom Luís da Cunha o precursor da ideia da transferência da corte para o Rio de Janeiro. (Da ordem imperial pombalina à fundação do império brasileiro, in OliveIRA, Luís Valente de; RICUPERO, Rubens (org.). A abertura dos portos, São Paulo, Senac, 2007, pág. 74.

${ }^{140}$ FreitAs, Caio de, op. cit. (nota 129), págs. 47-48.

${ }^{141}$ Idem, Ibidem, págs. 62-63. A oscilação do governo português, pendendo ora para o lado inglês, ora para o lado francês, pode causar estranheza. A explicação pode ser encontrada na divisão entre os minitros do Príncipe Regente. Havia uma corrente francófila, encabeçada por Antônio de Araújo, e outra anglófila, liderada por Rodrigo de Sousa Coutinho. Além da divisão do próprio gabinete, algumas circunstâncias agravavam as vacilações. Podemos tomar como exemplo um evento ocorrido em 1805, quando D. João descobriu uma conspiração para declará-lo louco e entregar o trono a D. Carlota. A própria mulher do Regente estava por trás do plano, fazendo com que o Príncipe visse conspirações em todos os cantos. Em consequência, recolheu-se D. João para o convento de Mafra, indo raramente até Lisboa. (cfr. MANCHESTER, Alan K., op. cit. (nota 128), pág. 58).
} 


\section{$\S^{0}$ - Reação inglesa ao fechamento e providências para transferência da}

corte. A notícia do fechamento dos portos à navegação inglesa não surpreendeu a Canning, que, na verdade, considerava tal medida inevitável.

Entretanto, causava irritação no Foreing Office a demora no cumprimento dos termos da Convenção Secreta. Com efeito, tudo estava pronto para a partida do Príncipe herdeiro do trono e, como informa Lorde Strangford -plenipotenciário inglês em Portugal -, todos os artigos necessários para a travessia já haviam sido embarcados e até mesmo os criados dormiam nas embarcações aguardando a partida pela manhã ${ }^{142}$.

No entanto, no julgamento do mesmo Strangford, a realização do intento de transferir a corte para o Brasil parecia mais distante do que nunca por conta da influência de "pessoas fracas e vis" que cercavam o Regente ${ }^{143}$.

Baseado nas notícias dos adiamentos, Canning redige instruções ao almirante Sir Sidney Smith e uma nota que, após ser assinado por Smith, deveria ser entregue por Strangford ao governo português. A nota levada pelo Almirante estava redigida sob duas formas, mas com o mesmo conteúdo. Por meio dela, comunicava-se ao governo português que o almirante havia chegado ao largo de Lisboa acompanhado de seu esquadrão naval para "proteger e comboiar até o Brasil Sua Alteza Real o Príncipe Regente ou parte da Família Real de Portugal que embarcasse na frota portuguesa caso não se realizasse o embarque da Família Real ${ }^{144, " . ~ A ~ o u t r a ~ v e r s a ̃ o ~ c o n t i n h a ~ u m ~ u l t i m a t u m ~ a o ~}$ governo português para que realizasse o embarque.

A recomendação era para que o Almirante Smith apostasse sua assinatura a ambas as versões da nota, entregando-as a Strangford que decidiria, a seu critério, qual seria encaminhada ao governo de Portugal. Instruiu-se, ainda, Smith a neutralizar a frota portuguesa no caso de não se efetivar a transferência da corte para que não caísse nas mãos dos franceses ${ }^{145}$.

$\$ 7^{\circ}$ - A transferência da corte portuguesa para o Brasil. Diante do assédio militar francês sobre Portugal, o governo cedeu ainda mais às pressões, a despeito da existência da Convenção Secreta e dos planos para deixar a Europa rumo à América: foi

\footnotetext{
${ }^{142}$ FreitAs, Caio de, op. cit. (nota 129), págs. 64-65.

${ }^{143}$ Idem, Ibidem, pág. 65.

${ }^{144}$ Idem, Ibidem, pág. 75.

${ }^{145}$ Idem, Ibidem, loc. cit.
} 
solicitado a Strangford que se retirasse do país, foram embargados os navios ingleses ancorados no Tejo e, em seguida, confiscaram-se os bens dos súditos ingleses residentes em Portugal. Strangford, no entanto, informou a Canning que o Príncipe Regente havia assinado tais disposições muito a contragosto, forçado que fora pela ala francófila de seu ministério $^{146}$.

Nota-se, portanto, que, neste momento, há a guinada portuguesa para o lado francês, o que acarreta, de imediato, o bloqueio da embocadura do Tejo por parte da frota inglesa.

As demonstrações do governo português, no sentido de uma aproximação em relação aos interesses franceses - como, por exemplo, o fechamento dos portos à navegação inglesa -, não tiveram o condão de fazer retroceder as ambições militares de Bonaparte sobre o país Ibérico. As ameaças prosseguiram com ainda maior intensidade e os rumores sobre uma possível invasão do território português aumentaram. Tropas napoleônicas continuava a entrar na Espanha e regimentos marchavam para a fronteira portuguesa. Ao mesmo tempo, um enviado de D. João partia de Lisboa rumo a Paris com "riquíssimos presentes de brilhantes" para oferecer a Napoleão e sua corte ${ }^{147}$.

Mesmo com o consentimento português diante das exigências francesas, a ideia da transferência da corte não havia desaparecido. Com efeito, a reunião do Conselho de Estado, realizada aos 09 de novembro de 1807, resolveu que D. João e toda sua corte embarcariam tão logo as tropas francesas cruzassem as fronteiras ${ }^{148}$.

Strangford, sentindo-se no dever de realizar uma última tentativa para levar a efeito o êxito da diplomacia inglesa, resolveu, por si só, voltar a Lisboa e realizar um apelo pessoal ao Príncipe Regente, que nutria pelo plenipotenciário inglês alguma consideração. O representante inglês procurou convencer D. João a tranferir a corte para o Brasil, argumentando com os nefastos efeitos que teria o bloqueio sobre Portugal. Propunha, alternativamente, a entrega da frota portuguesa à Grã-Bretanha ${ }^{149}$.

Enquanto aguardavam a resposta sobre a audiência com D. João, Strangford e Smith analisavam uma possível operação para aprisionar a frota portuguesa.

\footnotetext{
${ }^{146}$ FreitAs, Caio de, op. cit. (nota 129), págs. 81-82.

${ }^{147}$ Idem, Ibidem, págs. 81 e 83.

${ }^{148}$ Idem, Ibidem, pág. 82.

${ }^{149}$ Idem, Ibidem, pág. 87-88.
} 
A situação tornou-se ainda mais grave aos 24 de novembro de 1807, quando Smith oficializou o bloqueio e notícias chegaram a Lisboa de que tropas francesas já haviam ultrapassado a fronteira e chegado no Alentejo, sem que houvesse qualquer declaração de guerra por parte de Junot ${ }^{150}$.

Nas reuniões do Conselho de Estado dos dias 24 e 25, resolveu-se pela transferência da corte para o Brasil. O embarque foi agendado, em princípio, para o dia 27. Strangford, no dia 28, chegou a Lisboa para falar com o Príncipe Regente e foi informado que a maior parte da Família Real e da nobreza já havia embarcado. Ouviu, também, que D. João desejava falar-lhe com urgência, "a fim de saber da sua própria boca se as intenções da Inglaterra eram de tratá-lo como um amigo ou como um inimigo ${ }^{151 "}$ ".

Strangford foi informado de que D. João, mesmo após a invasão francesa, cria ser possível ajustar a situação sem a partida para o Brasil. O plenipotenciário inglês, diante da notícia, redigiu uma carta da D. João, afirmando que os atos de hostilidade frente a Inglaterra seriam esquecidos e prometeu proteção e auxílio no futuro, sob a condição de que a partida para o Brasil se realizasse até duas horas após o recebimento da carta ${ }^{152}$.

Após o dramático encadeamento de atos que acima muito resumimos, aos 29 de novembro de 1807, partia a corte portuguesa rumo ao Brasil, fato que mudaria a história de Portugal, do Brasil e que - dado que nos interessa particularmente - os rumos do comércio e do direito comercial na, até então, colônia.

\subsubsection{A chegada da Família Real e a abertura dos portos.}

$\$^{\circ}$ - O desembarque e as primeiras medidas em território brasileiro. D. João desembarca em Salvador aos 23 de janeiro de 1808. Parte da frota seguiu direto para o Rio de Janeiro por conta de uma tormenta enfrentada durante a viagem. O plenipotenciário inglês, Lorde Strangford, retornou para Londres - dado casual, mas que

\footnotetext{
${ }^{150}$ FreitAs, Caio de, op. cit. (nota 129), pág. 89-90.

${ }^{151}$ Strangford em carta a George Canning, apud FREITAS, Caio de, op. cit. (nota 129), pág. 91.

${ }^{152}$ Idem, Ibidem, pág. 92.
} 
pode ser considerado como relevante para o caráter que assumiu a abertura dos portos, como veremos a seguir $\left(\$ 3^{\circ}, \text { infra }\right)^{153}$.

A corte foi bem recebida pela população colonial, pois transformou o Brasil no centro decisório de todo o Império e a população pode desfrutar, em alguma medida, dos benefícios da proximidade da administração. Os principais órgãos foram transferidos de Lisboa para o Rio de Janeiro e a colônia "viu-se, de um dia para o outro, convertida no arcabouço de uma nação, física e socialmente quase estruturada, em pleno impulso de uma rápida definição orgânica ${ }^{154 \text { ", }}$

Deve-se observar, todavia, que, muito mais do que um mero deslocamento geográfico, a transferência da corte significou uma sensível modificação na própria orientação política do governo, já que passou para o primeiro plano das atenções a exploração das imensas potencialidades do território brasileiro. Com a administração portuguesa instalada no Brasil, o concerto europeu deixa de ser prioridade, ao mesmo tempo em que se atribui à colônia a responsabilidade de socorrer e defender a metrópole ${ }^{155}$.

A mudança da corte para o Brasil, por si só, não teria o condão de levar a efeito os objetivos de D. João no sentido de construir, deste lado do Atlântico, um "poderoso e rico império" para compensar a perda momentânea de Portugal, conforme a sugestão de Canning. Era necessária outra medida de ordem econômica: a abertura dos portos.

\section{$\$ 2^{\circ}$ - A carta régia de 28 de janeiro de 1808 e a abertura dos portos}

brasileiros às nações amigas. Após a transferência da corte para o Brasil, a abertura dos portos coloniais para o comércio, naquele momento, restrito ao tráfico com a metrópole, era uma medida inevitável ${ }^{156}$.

Tal inevitabilidade, contudo, não implica que o evento tivesse que necessariamente tomar os contornos que tomara. Isto é, se a abertura era inevitável - como

\footnotetext{
${ }^{153}$ Cfr. Ricupero, Rubens. O problema da abertura dos portos, in OliVEIRA, Luís Valente de; RiCUPERO, Rubens (org.). A abertura dos portos, São Paulo, Senac, 2007, pág. 32.

${ }^{154}$ FreitAs, Caio de, op. cit. (nota 129), págs. 137-138.

${ }^{155}$ Idem, Ibidem, págs. 138-139.

${ }^{156}$ Deve-se notar que a exclusividade de trocas econômicas entre colônia e metrópole não foi absoluta ao longo de todo o período colonial. A metrópole podia lançar mão de concessões a agentes privados e até a outros países para exploração do comércio com a costa da colônia. Informa ALAN K. MANCHESTER, por outro lado, que Portugal restringe sensivelmente o acesso de outras nações à costa brasileira após a descoberta de ouro e diamantes na colônia no século XVIII. (Cit. (nota 128), pág. 38).
} 
constatam sem grandes polêmicas os historiadores -, o caráter que ela assumiu poderia ter sido outra, caso fossem as circunstâncias diferentes ${ }^{157}$.

A inevitabilidade da medida foi reconhecida pelo Príncipe Regente. Apenas cinco dias após o desembarque na colônia, ainda em Salvador, D. João elaborou e promulgou a carta régia que abria os portos.

O preâmbulo da carta contém o reconhecimento de que havia suspensão, naquele momento, do comércio da Capitania da Bahia, com graves prejuízos para seus habitantes e da fazenda Real. A primeira disposição normativa admitia nas alfândegas da colônia quaisquer gêneros e mercadorias transportados em navios de bandeira portuguesa ou estrangeira das "Potências" que não estivessem em guerra com Portugal, pagando $24 \%$ por entrada; em seguida, autorizava-se que estrangeiros, além de portugueses e habitantes da colônia, pudessem exportar para os portos qualquer produto, com exceção do pau-brasil, ou "outros notoriamente estancados ${ }^{158, "}$

Com isso, punha-se ponto final no sistema colonial luso-brasileiro, pelo menos no que se refere ao seu aspecto econômico, pautado no exclusivo.

\footnotetext{
${ }^{157}$ Voltaremos ao caráter da abertura dos portos no parágrafo seguinte.

${ }^{158}$ Para facilitar o acesso ao documento, bem como por sua importância para o trabalho, transcrevemos, a seguir, o inteiro teor da carta régia: "Conde da Ponte, do meu Conselho, Governador e Capitão Geral da Capitania da Bahia. Amigo: Eu, o Príncipe Regente, vos envio muito saudar, como aquele que amo. Atendendo à representação, que fizeste subir à minha Real Presença, sobre se achar interrompido e suspenso o comércio desta Capitania, com grave prejuízo dos meus vassalos e da minha Real Fazenda, em razão das críticas e públicas circunstâncias da Europa; e querendo dar sobre este importante objeto alguma providência pronta e capaz de melhorar o progresso de tais danos: sou servido ordenar interina e provisoriamente, enquanto não consolido um sistema geral de efetivamente regula semelhantes materiais, o seguinte. Primo: que sejam admissíveis nas Alfândegas do Brasil todos e quaisquer gêneros, fazendas e mercadorias transportados, em navios estrangeiros das Potências, que se conservam em paz e harmonia com a minha Real Coroa, ou em navios dos meus vassalos, pagando por entrada vinte e quatro por cento; a saber: vinte de direitos grossos, e quatro do donativo, já estabelecido, regulando-se a cobrança destes direitos pelas pautas, ou aforamento, porque até o presente se regulam cada uma das ditas Alfândegas, ficando os vinhos, águas ardentes e aceites doces, que se denominam molhadas, pagando o dobro dos direitos, que até agora nelas satisfaziam. Segundo: que não só os meus vassalos, mas também os sobreditos estrangeiros possam exportar para os Portos, que bem lhes parecer a benefício do comércio e agricultura, que tanto desejo promover, todos e quaisquer gêneros e produções coloniais, à exceção do pau-brasil, ou outros notoriamente estancados, pagando por saída os mesmos direitos estabelecidos nas respectivas Capitanias, ficando, entretanto, como em suspenso e sem vigor, todas as leis, cartas régias, ou outras ordens que até aqui proibiam neste Estado do Brasil o recíproco comércio e navegação entre os meus vassalos e estrangeiros. O que tudo assim fareis executar com o zelo e atividade que de vós espero. Escrita na Bahia, aos 28 de janeiro de 1808. Príncipe para o Conde da Ponte".

A carta régia está integralmente transcrita em ARRUDA, José Jobson de Andrade, op. cit. (nota 127), págs. 150-151. A versão digitalizada da carta manuscrita pode ser acessada no acervo digital da Biblioteca Nacional do Brasil, por meio do endereço eletrônico < http://objdigital.bn.br/acervo_digital/div_manuscritos/mss1157496/mss1157496.pdf>, último acesso em 20 de dezembro de 2011.
} 
$\S^{\circ}$ - O caráter da abertura dos portos. Pode-se apontar, pelas razões que a seguir passaremos a expor, que a abertura dos portos brasileiros à navegação mercante internacional teve um caráter liberal.

O qualificativo liberal é sugerido por ALAN K. MANCHESTER ao comentar o papel de José da Silva Lisboa no evento, aduzindo que "o brasileiro merece crédito por conseguir fazer D. João decidir [pela abertura dos portos] e por sugerir uma medida tão liberal que todos os portos fossem abertos para todas as nações amigas ${ }^{159 "}$.

RUBENS RICUPERO noticia a existência de um documento sem data, mas possivelmente redigido antes da chegada do Príncipe Regente ao Rio de Janeiro, de autoria de José de Vasconcelos e Sousa, Marquês de Belas, em que há recomendação de abriremse os portos do Brasil "a todas as nações, sem exclusiva, para não dar um privilégio a uma só particular, o que seria uma espécie de escravidão ${ }^{160, "}$.

\section{$\S^{\circ}$ - A concorrência de José da Silva Lisboa para o caráter da abertura}

dos portos. Não há dúvidas de que, ao recomendar a abertura sem privilégios a qualquer nação, o marquês de Belas tinha em mente a Inglaterra, que ambicionara, na Convenção Secreta de 22 de outubro de 1807, o estabelecimento de um porto exclusivamente britânico na ilha de Santa Catarina, caso os portos portugueses fossem fechados aos ingleses.

O referido artigo não foi ratificado por Portugal, mas revela que as intenções inglesas não correspondiam a uma abertura dos portos brasileiros a todas as nações. Com efeito, a diplomacia inglesa pretendia obter junto à corte portuguesa privilégios comerciais e alfandegários, o que só foi possível dois anos mais tarde, quando da assinatura dos tratados de $1810^{161}$.

\footnotetext{
${ }^{159}$ MANCHESTER, Alan K, op. cit. (nota 128), pág. 70, nota de rodapé $\mathrm{n}^{\circ} 4$ - tradução livre.

${ }^{160}$ Apud RiCUPERO, Rubens, op. cit. (nota 153), pág. 30.

${ }^{161}$ Neste sentido, cfr. AlAN K. MANCHESTER: "Canning tentou assegurar um porto aberto para os produtos ingleses na costa do Brasil ao tempo da convenção secreta de 22 de outubro, mas o príncipe regente recusou a ratificação do artigo adicional que concedia o privilégio aos ingleses. Agora, pelo decreto de 28 de janeiro, D. João abriu todos os portos do Brasil ao comércio de todas as nações amigas de Portugal, enquanto a GrãBrenha tinha reclamado um porto aberto apenas para a Inglaterra. Mais tarde, quando o príncipe regente, após chegar ao Rio de Janeiro, questionou Mr. Hill, encarregado na ausência do ministro Strangford, se a Inglaterra estava satisfeita com o decreto de 28 de janeiro, recebeu a respostas de que a medida 'não poderia deixar de produzir bons efeitos na Inglaterra, mas que, se tivesse autorizado a admissão de embarcações e de manufaturas inglesas em termos mais vantajosos que aqueles garantidos para Navios e Mercadorias de outra nações estrangeiras, teria, necessariamente, gerado maior satisfação'”. (Cit. (nota 128), pág. 71).
} 
Para RiCUPERO, a abertura dos portos "foi um raro momento de eclipse

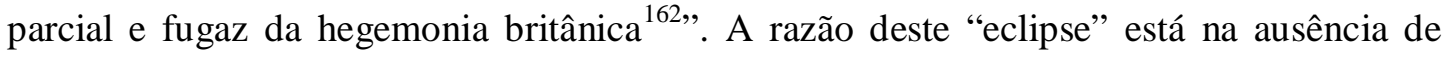
qualquer representante dos interesses ingleses no momento da resolução pela abertura. Além disso, a presença de José da Silva Lisboa ganha destaque, pois o futuro Visconde de Cairú era fiel seguidor das ideias liberais de Adam Smith e colocou-se, sempre, contrário a concessão de quaisquer privilégios a nações ou seguimentos econômicos.

Em resumo, portanto, pode-se apontar que a abertura dos portos era, sim, uma medida desejada pelos ingleses, mas o modo liberal como ela foi realizada não correspondia integralmente aos intentos britânicos ${ }^{163}$.

Na linha de argumentação de RUBENS RICUPERO, é possível afirmar que a participação de Silva Lisboa na abertura dos portos, embora não tenha sido decisiva para a efetivação da decisão, foi importante para caráter o caráter liberal que ela assumiu. O papel futuro Visconde é muito debatido na historiografia. Tradicionalmente, atribui-se a ele uma atuação quase heróica, como tendo sido fundamental para a decisão de abrir os portos brasileiros.

Podemos encontrar as raízes desta visão na obra do próprio José da Silva Lisboa, que escreveu em suas Observações sobre o comércio franco no Brasil, que participou da "honra de concorrer para a direta resolução soberana, sendo ouvido em qualidade especial $^{164,}$,

JOSÉ Luís CARDOSO aponta também o testemunho de Dona Gabriela, mulher de Rodrigo de Sousa Coutinho, que afirmou ter sido a amizade que mantinha com Dom Fernando José de Portugal, marquês de Aguiar e futuro presidente da Real Junta de Comércio, Agricultura, Fábricas e Navegação deste Estado do Brasil, que garantiu a Lisboa a audiência com o Príncipe Regente ${ }^{165}$.

Também Bento da Silva Lisboa, filho do Visconde, assevera a importância do pai na resolução de D. João VI.

\footnotetext{
${ }^{162}$ RICUPERO, Rubens, op. cit. (nota 153), pág. 34.

${ }^{163}$ Neste sentido, veja-se RUBENS RICUPERO: "É anacronismo histórico atribuir à Inglaterra protecionista e exclusivista de 1807-1808 a posição de advogada do irrestrito livre comércio internacional (...)”. (RICUPERO, Rubens, op. cit. (nota 153), pág. 32.)

${ }^{164}$ LisboA, José da Silva. Observações sobre o comércio franco no Brasil, in RochA, Antonio Penalves. José da Silva Lisboa, Visconde de Cairu, São Paulo, 34, 2001, pág. 66.

${ }^{165}$ CARdoso, José Luís. A transferência da corte a abertura dos portos:Portugal e Brasil entre a ilustração e o liberalismo econômico, in OLIVEIRA, Luís Valente de; RICUPERO, Rubens (org.). A abertura dos portos, São Paulo, Senac, 2007, pág. 183.
} 
Exemplo da linha que heroicisa Cairu encontramos em FRANCISCO ADOLFO DE VARNHAGEN, para quem a abertura se deu "seguindo insinuação de José da Silva Lisboa (Cayrú)", e, como prova da importância de Lisboa, apresenta a criação, pelo Príncipe Regente, da aula pública de ecomonia política a ser regida por Silva Lisboa por ter ele “dado provas de ser muito hábil para o ensino daquella sciencia, sem a qual se caminha ás cegas e com passos mui lentos $(. . .)^{166, "}$.

Comum também entre os juristas o tom laudatório à atuação de Lisboa, como se verifica em WALDEMAR FERREIRA, que argumenta com a importância que já gozavam as obras de Cairu no momento da chegada da Família Real ao Brasil:

“(...)o príncipe regente de Portugal, aportando na Bahia, ali se deteve, entre homens de bom conselho, que o acolheram e cercaram, destacou-se JosÉ DA SILVA LISBOA. Formado na vetusta Universidade de Coimbra, notabilizara-se como economista e como comercialista. Dois grandes livros havia já editado em Lisboa - os Princípios de Economia Política, em 1804; e os Princípios de Direito Mercantil e Leis da Marinha, de 1798 a 1804

(...)

Aquele grande jurisconsulto, valendo-se das circunstâncias e demonstrando largueza de vista, sugeriu a D. JỗO, em sua passagem pela Bahia, a abertura dos portos do Brasil ao comércio estrangeiro, levada a efeito pela carta régia de 28 de janeiro de 1808 (...)"167.

\footnotetext{
${ }^{166}$ VARnhagen, Francisco Adolpho de. História Geral do Brazil, tomo II, Rio de Janeiro, Laemmert, 1857, págs. 314-315.

${ }^{167}$ FerreIRA, Waldemar Martins. Instituições de direito comercial, vol. I, $3^{\mathrm{a}}$ ed., Rio de Janeiro, Freitas Bastos, 1951, pág. 47. Também J.X. CARVAlHo DE MendonçA destaca o papel de Cairu (CARVAlHo DE MENDONÇA, José Xavier, op. cit. (nota 21), pág. 71). No mesmo sentido, AlFREDO DE AlMEIDA RuSSELL: “A carta régia de 28 de Janeiro de 1808 abriu os portos do Brasil ao comércio direto estrangeiro sob inspiração de José Da Silva Lisboa (...).” (Curso de direito comercial, vol. I, parte I, Rio de janeiro, Borsoi, 1938, pág. 54)

Interessante observar que as obras de José da Silva Lisboa não gozavam de unânime prestígio entre seus contemporâneos. Em um opúsculo publicado anonimamente por MANOEL LUís DA VEIGA, chamado Reflexões criticas sobre a obra de José da Silva Lisboa, intitulada, Principios de direito mercantil: feitas por hum homem da mesma profissão, disponível na Biblioteca Nacional, no Rio de Janeiro, e também em formato digital no projeto Brasiliana USP, onde se encontra em versão integral, lê-se o seguinte na página IV do prólogo: “(...) conhecendo eu as incoherencias, contradicções, e infinitas repetições, de que está cheio aquelle Tratado [Princípios de direito mercantil], tomei seria resolução de os desenganar, mostrando-lhes claros todos os defeitos, que nelle se encontrão; pelos quaes se pode julgar do trabalho do Author, conferindo estas minhas Reflexões Criticas, com hum dos Exemplares de que me servi naquelle exame”. Mais adianta, na página 6, o autor continua com ácida crítica: “A obrigação de hum Edictor he de decidir as questões que elle incitar na sua obra; e caso queira corroborar com authoridades alheias, só deve referir os Escritores a quem se reporta, depois de ter cabalmente provado as suas proposições, a que deo principio: porém não succede assim com o nosso Author dos Principios de Direito Mercantil, o qual fere o argumento, e deixa a Emerigon o cuidado de o provar". O autor das reflexões críticas não poupa LiSBOA das questões de metodologia nas páginas 22 e 26: "He de falta de methodo, de que nasce a indigestão, quasi de todas as obras em que se encontrão repetições; principalmente daquella dos Principios de Direito Mercantil, de que falamos nestas Reflexões. (...) Se os homens que [es]crevem, e publicão os seus pensamentos, o[s] não dispõem pela ordem, methodo, e estilo, q[u]e requer o gosto do tempo, sacrificão-se o mesmo a que sacrificou o nosso Filosofo, Author dos Principios de Direito Mercantil. Todos desejão inculcar e fazer eterno o seu Nome por
} 
Em outra banda, há autores, como, por exemplo, o jornalista LAURENTINO GOMES que diminuem sensivelmente o papel de Lisboa, aduzindo que sua participação é um mito, na medida em que a abertura era inevitável ${ }^{168}$.

CAIO DE FREITAS, por sua vez, ao analisar escritos de Strangford, conclui que D. João, ao desembarcar para o Brasil, tinha no espírito a preocupação de oferecer aos ingleses uma compensação pela ruptura no comércio anglo-lusitano. Desse modo, é possível notar que a abertura dos portos é o resultado de longos debates iniciados ainda em Portugal, o que comprovaria uma diminuta participação de José da Silva Lisboa ${ }^{169}$.

JoSÉ JOBSON DE ANDRADE ARRUDA não credita a Silva Lisboa um papel heroicisado, afirmando que a opinião mais sensata a respeito do desempenho do baiano na abertura dos portos teria sido a de JOÃo LUCIO AZEVEDO, para quem o pensamento de Silva Lisboa, transmitido diretamente a D. João, possa ter concorrido para a resolução final, mas não tê-la determinado por si só ${ }^{170}$.

Parece, todavia, assistir razão a RUBENS RICUPERO, que não atribui a Silva Lisboa papel fundamental na decisão que resultou no Decreto de 28 de janeiro de 1808, mas que credita ao baiano desempenho decisivo em relação ao caráter liberal assumido pela abertura dos portos. Para o autor, ausente Silva Lisboa e presente Strangford, a Inglaterra, desde logo, teria conseguido seus almejados privilégios comerciais ${ }^{171}$.

$\$ 5^{\circ}$ - As nações amigas de Portugal. Outra questão que se costuma levantar ao debater a abertura dos portos diz respeito a quais seriam as nações amigas de Portugal para quem estariam abertos os portos brasileiros.

Tradicionalmente, por se entender que a Inglaterra - grande fomentadora desta medida - era o único país verdadeiramente interessado na abertura, costuma-se apontar esta nação como a única amiga de Portugal disposta a comerciar diretamente com

meio das Letras, e das suas Obras; porém poucos ha que se sujeitem ao estudo, mortificação, trabalho, paciência, e cultura, que ellas requerem antes de se publicarem, sahirem das mãos do seu Author". ([VEIGA, Manoel Luís da]. Reflexões críticas sobre a obra de José da Silva Lisboa, intitulada, Principios de Direito Mercantil: feitas por hum homem da mesma profissão, Lisboa, Antonio Rodrigues Galhardo, 1803)

${ }^{168}$ GOMES, Laurentino, op. cit. (nota 126), pág. 107.

${ }^{169}$ FreitAS, Caio, op. cit. (nota 129), págs. 145-146.

${ }^{170}$ ARRUDA, José Jobson de Andrade, op. cit. (nota 127), pág. 125.

${ }^{171}$ RiCUPERO, Rubens, op. cit. (nota 153), págs 24-30. 
o Brasil, visando o escoamento de sua produção, obtenção de matérias primas especialmente, algodão - para sua indústria e reinverter a balança comercial, ora negativa, frente Portugal.

Que a Inglaterra tivesse grande interesse na abertura dos portos não se pode negar. Além disso, considerando o contexto europeu, com o Bloqueio Continental imposto aos países dominadas por Napoleão, somado à dominação britânica dos mares, pode-se afirmar que a Inglaterra seria a única nação européia em condições de comerciar com o Brasil. Entretanto, não é possível afirmar com correção que seria ela a única nação do globo a se beneficiar da abertura ${ }^{172}$.

Com efeito, como bem aduz, novamente, RUBENS RICUPERO os Estados Unidos da América já realizavam trocas com os países hispano-americanos e estavam interessados em estender este comércio ao Brasil ${ }^{173}$. Neste mesmo sentido, FERNANDO NovAIS aponta que o país norte-americano tentou firmar com Portugal um tratado de comércio, intento que foi frustrado, pois insistia-se em obter licença para comerciar diretamente nos portos do Brasil ${ }^{174}$.

Mais que isso, José JOBSOn DE ANDRADE ARRUDA aponta, pelos dados da balança comercial brasileira e pela presença de navios estrangeiros nos portos da colônia, que já havia, no período entre 1800 e 1808, muito mais nações comerciando com o Brasil do que poderia sugerir a existência do exclusivo metropolitano. No ano de 1800, por exemplo, aportaram no Rio de Janeiro 70 (setenta) navios estrangeiros, indicativo que, por meio do contrabando, o comércio colonial não se restringia às trocas com a metrópole ${ }^{175}$.

Portanto, não é correto afirmar que a única nação disposta ao comércio com o Brasil fosse a Inglaterra e que a abertura dos portos tenha sido uma medida que atendia exclusivamente aos interesses britânicos. Pelo contrário, é possível até mesmo aduzir que, na prática, os portos brasileiros já se encontravam abertos pelo contrabando e que a carta régia de 28 de janeiro de 1808 nada mais foi que o reconhecimento oficial de uma situação de fato, como vemos a seguir.

\footnotetext{
172 Neste sentido, veja-se LAURENTINO GOMES: “Além disso, a liberação do comércio internacional na colônia era uma dívida que D. João tinha com a Inglaterra. Foi o preço que pagou pela proteção contra Napoleão devidamente negociado em Londres em outubro de 1807 pelo embaixador português D. Domingos de Sousa Coutinho" (GoMES, Laurentino, op. cit. (nota 126), pág. 107).

${ }^{173}$ RICUPERO, Rubens, op. cit. (nota 153), pág. 31.

${ }^{174}$ Novais, Fernando. Portugal e Brasil na crise do antigo sistema colonial (1777-1808), $4^{\mathrm{a}}$ ed., São Paulo, Hucitec, 1986, pág. 185.

${ }^{175}$ ARRUDA, José Jobson de Andrade, op. cit., (nota 127), pág. 116. Sobre a presença de navios estrangeiros na costa brasileira e o contrabando colonial, voltaremos no parágrafo seguinte.
} 


\section{$\$ 6^{0}$ - Uma pré-abertura dos portos? A tese de José Jobson de Andrade}

Arruda. FERNANDO NOVAIS aponta que licenças, concessões da metrópole a mercadores estrangeiros, assim como o contrabando, são variações em torno do elemento fundamental do sistema colonial, qual seja, o exclusivismo metropolitano do comércio colonial ${ }^{176}$.

Além da pressão norte-americana para obter uma licença para comerciar diretamente na costa brasileira (vide item 2.1.2, $\S 5^{\circ}$, supra), o contrabando era, igualmente, uma pressão sobre o exclusivo metropolitano. Como aponta FERnANDo NovAIS, à frente do contrabando estavam ingleses, mas havia, também, americanos, franceses, suecos e dinamarqueses rompendo, com sucesso, o sistema colonial ${ }^{177}$.

JOSÉ JOBSON DE ANDRADE ARRUDA informa que, por volta de 1785, o ministro da marinha portuguesa, Martinho de Melo e Castro, chegou ao ponto de sugerir a redução das taxas alfandegárias para desestimular o comércio ilegal, medida esta que foi, efetivamente, posta em vigência quando, em 1792, exportou-se açúcar brasileiro livre de quaisquer $\operatorname{taxas}^{178}$.

Este "rompimento das malhas do exclusivo" significava, no julgamento de JoSÉ JOBSON DE ANDRADE ARRUDA, “a abertura informal dos portos brasileiros”, passando o contrabando a ser parte da sociedade colonial e deixando de ser visto como algo contrário à ética ou à moralidade. Tanto é assim que, por volta de 1790, os comerciantes brasileiros realizavam as trocas ilegais às vistas dos funcionários encarregados da vigilância, contando com a conivência destes ${ }^{179}$.

O autor experimenta um exercício de quantificação do comércio contrabandista por meio da análise da balança comercial entre Portugal e sua colônia, o Brasil. Em um sistema monopolista, as taxas de crescimento das importações e exportações deveriam ser equivalentes, "pois não havia a possibilidade de incremento das exportações sem a proporcional importância de insumos básicos ${ }^{180,}$.

A partir de 1800, no entanto, observa-se a redução das importações da colônia. Este dado indica que, se a metrópole exportava menos para a colônia, esta - a

\footnotetext{
${ }^{176}$ NovAIS, Fernando, op. cit. (nota 174), págs. 91-92.

${ }^{177}$ Idem, Ibidem, pág. 185.

${ }^{178}$ ARRUDA, José Jobson de Andrade, op. cit., (nota 127), pág. 112.

${ }^{179}$ ARRUDA, José Jobson de Andrade, op. cit., (nota 127), págs. 113-114.

${ }^{180}$ Idem, Ibidem, págs. 115-116.
} 
colônia - importava os bens de que necessitava de outros fornecedores. Diante deste quadro, JOSÉ JOBSON DE ANDRADE ARRUDA propõe a questão: “(...) seria excessivo afirmar que os portos brasileiros foram gradualmente abertos a partir de 1800 e simplesmente formalizados em 1808?” O autor conclui que não seria excessivo e que, aos 28 de janeiro de 1808, os portos brasileiros já se encontravam, de fato, abertos à navegação estrangeira $^{181}$.

Para corroborar essa conclusão, pode-se observar a tabela abaixo, que indica o número de navios estrangeiros que atracaram no porto do Rio de Janeiro entre 1791 e 1810:

\begin{tabular}{|l|l|l|l|l|}
\hline $1791=9$ & $1795=26$ & $1799=39$ & $1803=54$ & $1807=47$ \\
\hline $1792=34$ & $1796=16$ & $1800=70$ & $1804=54$ & $1808=70$ \\
\hline $1793=29$ & $1797=24$ & $1801=64$ & $1805=38$ & $1809=83$ \\
\hline $1794=19$ & $1798=27$ & $1802=51$ & $1806=59$ & $1810=122$ \\
\hline
\end{tabular}

Fonte: Arquivo Nacional, Rio de Janeiro, caixas 492 e 493, códices 156 e 157, citado por ARRUDA, José Jobson de Andrade, op. cit., (nota 127), pág. 116.

No período entre 1791 e 1807, vigia, ainda, o sistema de monopólio. A despeito disso, nota-se, a partir de 1800, um expressivo aumento no número de navios estrangeiros - praticamente duplicado em relação ao ano anterior. Para JOSÉ JOBSON, este aumento pode ser interpretado da seguinte forma:

"Se admitirmos que as exigências do sistema colonial comportava certa flexibilidade para entender as excepcionalidades da vida no mar e que, portanto, a média de 24 navios no período poderia ser considerada normal, os 70 navios entrados na barra do Rio de Janeiro em 1800 representam um salto imprevisto, indicativo de que mudanças estruturais estavam ocorrendo nas relações comerciais externas da colônia, mesmo se considerando a redução das freqüências nos anos que se seguiram até 1807. (...) Se compararmos as 70 presenças em 1800 com as 90 de 1808, fácil é concluir que os portos estavam abertos, pelo menos o do Rio de Janeiro, para o qual temos uma evidência palpável, mas se a experiência histórica no porto da capital da colônia era essa, o mesmo poderíamos presumir para o restante da rede portuária, onde o aparato repressor era menos eficiente" ${ }^{, 182}$.

\footnotetext{
${ }^{181}$ Idem, Ibidem, pág. 116.

182 ARruDA, José Jobson de Andrade, op. cit. (nota 127), pág. 117.
} 
Outro dado que corrobora a existência desta abertura informal dos portos brasileiros a partir de 1800 é a abrupta retração da indústria portuguesa após este ano, justamente pela progressiva perda do mercado brasileiro.

\section{A indústria portuguesa apresentava, até o final do século XVIII,} considerável tendência à expansão, resultado, entre outros fatores, da política nacionalista no âmbito econômico inaugurada no reinado de D. José I, pelas mãos de seu ministro, o Marquês de Pombal.

Por conta do Tratado de Methuen (1703), a disponibilidade pecuniária existente em Portugal advinda do ouro que chegava do Brasil escoava para a Inglaterra por causa da diferença de valor entre as mercadorias importadas e exportadas entre os países. Pombal, ao assumir o poder, deparou-se com essa situação. Desde o primeiro momento, teve em mente reabilitar a economia portuguesa, livrando-a dos arbítrios dos negociantes ingleses, por quem nutria grande ojeriza desde os tempos em que fora funcionário diplomático em Londres ${ }^{183}$.

Pombal comandou uma série de medidas de cunho protecionista tomadas pelo governo português com o propósito de fortalecer a economia nacional por meio da diminuição da dependência frente à Inglaterra. Por meio da Lei de 13 de outubro de 1752, o juiz conservador inglês foi proibido de dar mandados para impedir a execução de sentenças ou ordens prolatadas pelas cortes ordinárias, sob pena de suspensão de 06 (seis) meses $^{184}$; o alvará de 07 de junho de 1755 criou a Companhia do Grão-Pará e Maranhão,

${ }^{183}$ FreITAS, Caio de, op. cit. (nota 129), págs. 109-111. A respeito da submissão de Portugal à Inglaterra, Pombal escreveu as seguintes palavras, ao tempo do terremoto em Lisboa: “A monarquia portuguesa estava no seu último suspiro. Os ingleses tinham atado firmemente a nação a um estado de dependência. Eles a conquistaram sem o inconveniente da conquista (...). Portugal estava sem poder e sem vigor, e todos os seus movimentos estavam regulados pelos desejos da Inglaterra. (...) Em 1754, Portugal mal produzia qualquer produto para seu próprio sustento. Dois terços de suas necessidades eram supridos pela Inglaterra. (...) A Inglaterra havia se tornado a senhora de todo o comércio português, e todo o tráfico do país era efetivado por seus agentes. Os ingleses eram, ao mesmo tempo, os fornecedores e os varejistas de todas as necessidades da vida que o país requeria. Tendo o monopólio de tudo, nenhum negócio era levado a efeito, senão pelas suas mãos (...).

Os ingleses vieram a Lisboa para monopolizar até mesmo o comércio do Brasil. Toda a carga das embarcações que eram para lá enviadas e, consequentemente, as riquezas que eram trazidas como troca, pertenciam a eles. (...) Esses estrangeiros, depois de ter adquirido imensas fortunas, desapareciam repentinamente, carregando com eles a riqueza do país”. (apud MANCHESTER, Alan K., op. cit. (nota 128), pág. 39)

${ }^{184}$ Dispunha a referida Lei: “(...) Ordeno, e mando, que da publicação desta Lei em diante nenhum Conservador passe contramandados vagos, e geraes para se deixarem de fazer com qualquer pessoa as diligencias de Justiça, sob pena de seis mezes de suspensão dos lugares, que occuparem no Meu Real serviço por cada contramandado, que expedirem na referida forma; (...)”. A Lei pode ser consultada na Collecção da legislação portugueza, Lisboa, Maigrense, 1830, págs. 144 e 145. A coleção está disponibilizada em versão 
dispondo que todo navio que partisse para as províncias do Grão-Pará e do Maranhão deveria partir de Lisboa e pertencer à Companhia ${ }^{185}$; aos 16 de dezembro de 1756, aprovam-se, por alvará, os estatutos da Junta do Commercio, com poderes de regular e fiscalizar o comércio, além de julgar as causas comerciais. A junta considerou contrabando uma longa lista de produtos.

A política de Pombal deu resultados e o comércio entre Inglaterra e Portugal diminuiu significativamente. Diante deste quadro, agentes do governo inglês realizaram estudos e atestaram que o aumento ou diminuição do comércio anglo-português dependia do comércio com o Brasil. As companhias monopolistas e a Junta do Commercio ameaçavam privar a Inglaterra de qualquer participação nas trocas com a colônia ${ }^{186}$.

Por essas e outra medidas, a produção portuguesa cresceu e tendia a continuar crescendo. Observa-se, no entanto, no ano de 1800, uma inversão nesta tendência e uma vertiginosa queda. Conforme JosÉ JobSON DE ANDRADE ARRUDA, os valores exportados giravam, em 1800, em torno de 5.500 contos de réis, regredindo para 500 contos de réis em oito anos. A partir desses dados, é possível concluir que o contrabando era um mecanismo de pressão pela abertura dos portos brasileiros e que, efetivamente, o comércio ilegal significou uma abertura não oficial dos portos brasileiros antes da cartarégia de 28 de janeiro de $1808^{187}$.

Tanto é verdade que MAURícIO JOSÉ TEIXEIRA DE MORAES, encarregado por apresentar anualmente a balança de comércio ao governo português, escrevia na introdução da balança de 1802: "E queira que a sorte não suceda o mesmo nos anos futuros pela abundância de contrabando que se introduz na América(...)"188.

A questão do contrabando e da abertura de fato dos portos brasileiros ao comércio internacional é importante para nosso trabalho, pois revela que boa parte das trocas comerciais brasileiras era efetivada fora do sistema oficial e, assim, não chegava aos tribunais, dado que, sem dúvida, influenciou na formação do direito mercantil, como passaremos a expor em seguida.

digital no portal Ius Lusitaniae, no endereço eletrônico < http://iuslusitaniae.fcsh.unl.pt/>, último acesso em 04 de dezembro de 2011.

${ }^{185}$ Collecção da legislação portugueza, Lisboa, Maigrense, 1830, págs. 391-392.

${ }^{186}$ MANCHESTER, Alan K., op. cit. (nota 128), págs. 45-46.

${ }^{187}$ ARRUDA, José Jobson de Andrade, op. cit (nota 127), pág. 118.

${ }^{188}$ MoRAes, Maurício José Teixeira de. Introdução da balança geral do commercio do Reyno de Portugal e seus domínios, Lisboa, 1802. O trecho citado está transcrito por ARRUDA, José Jobson de Andrade, op. cit. (nota 139), págs. 146-147. 


\subsection{3 - Consequências da abertura dos portos: a ascensão de uma nova} elite, um "novo" aparato burocrático e utilização da legislação estrangeira para integração de lacunas do Direito Comercial luso-brasileiro.

A abertura dos portos mudou significativamente a vida na colônia em, pelo menos, três diferentes âmbitos, além do econômico: o âmbito social, o da administração da justiça e o jurídico. Vejamos, a seguir, alguns apontamentos sobre o que ocorreu no Brasil após a carta régia de 28 de janeiro de 1808 .

$\$ 1^{\circ}$ - Consequências sociais. As consequências sociais da abertura dos portos trazem embutidas também uma consequência política, que é a formação de uma classe negociante capaz de influir nos rumos das decisões tomadas pelo governo instalado no Rio de Janeiro.

Desde meados do século XVIII, em parte como efeito da política de Pombal, constitui-se em Portugal, principalmente em Lisboa, uma classe de comerciantes que, a partir da criação da Junta do Commercio deste Reino e Seus Domínios, ao mesmo tempo representativo e regulador, passava a definir os requisitos de ingresso na profissão como a obrigatoriedade da matrícula, a atribuição de privilégios fiscais e simbólicos e a identificação dos homens de negócios como destinatários de medidas legislativas ${ }^{189}$.

Após a transferência da corte para o Brasil e a criação da Real Junta do Comércio, Agricultura, Fábricas e Navegação, aos 23 de agosto de 1808, "mais do que uma comunidade, uma corporação se forma, contanto com a participação de negociantes e magistrados, que defendem seus interesses corporativamente nos quadros da monarquia, em uma sociedade que se imaginava e organizava semelhantemente a um corpo ${ }^{190}$,.

Os grandes negociantes foram capazes de acumular capitais antes da chegada da Família Real, o que lhes permitiu utilizar sua disponibilidade de recursos para interferir, diretamente, na economia, por meio da concessão de crédito, do fornecimento de mão-de-obra, do abastecimento, das importações e das exportações. Observa-se, ao mesmo

\footnotetext{
${ }^{189}$ LOPES, Walter de Mattos, op. cit. (nota 125), pág. 111.

${ }^{190}$ Idem, Ibidem, pág. 112.
} 
tempo, o surgimento da especialização entre produção e comercialização, levando os produtores a perder o controle sobre o todo o processo até a chegada do destinatário final. Como intermediários, os negociantes subordinam os produtores e o aumento da circulação de capital, possibilitou o aumento de representantes dos negociantes na vida pública ${ }^{191}$.

É importante anotar que esta classe passou a financiar até mesmo a Coroa. Em suas crises financeiras, a Corte instalada no Rio de Janeiro contava com empréstimos feitos por comerciantes em troca de graças honoríficas e lugares de prestígio. Já em 1808, são realizadas subscrições para auxiliar a guerra contra os franceses que se travava na metrópole. Os comerciantes do Rio de Janeiro contribuíram para os esforços bélicos com gêneros úteis para o provimento dos exércitos ${ }^{192}$.

Para o monarca, este financiamento era retribuído de maneira muito barata, pois bastava "distribuir fartamente graças honoríficas, as quais davam mais prestígio social do que renda aos seus favorecidos ${ }^{193}$ ".

Portanto, pode-se concluir que, após a transferência da Família Real e da abertura dos portos, assiste-se, no Brasil, o advento de uma classe social com disponibilidade de recursos e capacidade de influir de maneira decisiva nos rumos políticos do império luso-brasileiro.

Os interesses desses negociantes não são, necessariamente, os mesmos da tradicional elite agrária brasileira. No entanto, a progressiva ascensão da classe comerciante ao poder não significa a sobreposição dos interesses dos grupos tradicionalistas. Com efeito, a produção jurídica nos anos de formação do Brasil indica a articulação de novos interesses - pautados nos modernos códigos europeus -, com aqueles da elite agrária escravista - pautados, ainda, nas vetustas Ordenações Filipinas ${ }^{194}$.

JoSÉ REINALDO DE LIMA LOPES corrobora a existência desta peculiaridade da produção jurídica brasileira nos anos de formação do Estado. O autor aponta para a

\footnotetext{
${ }^{191}$ NeVES, Edson Alvisi. O tribunal do comércio: magistrados e negociantes na corto do império do Brasil, Rio de Janeiro, Jurídica do Rio e Janeiro/Faperj, 2008, págs. 46-47.

${ }^{192}$ Silva, Maria Beatriz Nizza. A Gazeta do Rio de Janeiro (1808-1822): cultura e sociedade, Rio de Janeiro, EdUERJ, 2007, pág. 175.

${ }^{193}$ Idem, Ibidem, pág. 176.

${ }^{194}$ NeVES, Edson Alvisi, op. cit. (nota 191), pág. 46.
} 
constante ambiguidade entre medidas liberais combinadas a outras típicas do Antigo Regime $^{195}$.

$\$ 2^{\circ}$ - Consequências no âmbito administrativo da colônia. A consequência administrativa mais imediata que se deu logo após a abertura dos portos foi a criação da Real Junta de Comércio, Agricultura, Fábricas e Navegação, por alvará de 23 de agosto de 1808. O tribunal da Real Junta permaneceu ativo até 1850 e foi, ao longo deste período, "pedra fundamental na resolução de conflitos jurisdicionais nos quadros do Império lusobrasileiro $^{196,}$.

Até então, enquanto colônia e território de conquista, o Brasil não participava da administração do comércio, situação que muda quando a corte cruza o Atlântico. A fundação do tribunal do comércio em 1808 revela a continuidade das estruturas administrativas do Antigo Regime ao longo do século XIX, ao mesmo tempo em que abre espaço na administração pública para a os homens de negócio, a verdadeira elite do Primeiro Reinado, como afirma WALTER DE MATtos LoPES seguindo SÉRGio BUARQUe DE HOLANDA ${ }^{197}$.

A intenção do Príncipe Regente era de regular o novo tribunal nos mesmos moldes em que vinha sendo regulada a Real Junta de Lisboa, criada por Pombal:

“Governar-se-ha por todas as Leis, Alvarás, Regimentos e Ordens Regias que se acham estabelecidas nesta materia e especialmente pela Carta de lei de 5 de junho de 1788 ".

\footnotetext{
${ }^{195}$ LIMA LOPES, José Reinaldo. Iluminismo e jusnaturalismo no ideário dos juristas da primeira metade do século XIX, in JANCSÓ, István. Brasil: formação do estado e da nação, São Paulo-Ijuí Hucitec-Unijuí, 2003, pág. 195.

${ }^{196}$ LOPES, Walter de Mattos, op. cit. (nota 125), pág. 28.

${ }^{197}$ Idem, Ibidem, pág. 28. A própria redação do seu alvará de criação, publicado, como já afirmado, aos 23 de agosto de 1808, revela a intenção de continuidade em relação à Junta criada por Pombal em 1756: “(...): e desejando que tão uteis vantagens se consigam neste Estado, que nas actuaes circumstancias necessida muitas providencias e socorros, para que cresçam e se augmentem estes objectos de publica felicidade: e sendo de esperar que da creação de um Tribunal semelhante ao de Portugal, que entenda e providencie em todos os objectos desta natureza, resultem grandes utilidade em beneficio comum dos meus fieis vassallos habitantes deste vasto e feliz continente, que hão mister maiores e mais aptas providencias a este repeito; (...)" (Collecção das leis do Brazil de 1808, Rio de Janeiro, Imprensa Nacional, 1891, pág. 105, disponível em http://www.camara.gov.br/Internet/InfDoc/conteudo/Colecoes/Legislacao/Legimp-A1_29.pdf - grifo nosso)
} 
A carta de lei de 05 de junho de 1788 transformava a Real Junta portuguesa de 1755 em "tribunal supremo", em que se deveria examinar todas as matérias que tivessem relação com a conservação e incremento do comércio, agricultura, indústria e navegação ${ }^{198}$.

Nos seus 42 anos de funcionamento, a Real Junta criada em 1808 assumiu três diferentes denominações: a primeira, como vimos, Real Junta do Comércio, Fábricas, e Navegação deste Estado do Brasil e Seus Domínios Ultramarinos; quando, em 1815, o Brasil passou a ser Reino Unido a Portugal e Algarves, o tribunal recebeu o nome de Real Junta do Comércio, Agricultura, Fábricas, e Navegação deste Reino e Seus Domínios Ultramarinos; após a separação política em relação a Portugal, passou-se a Real Junta do Comércio, Agricultura, Fábricas, e Navegação do Império do Brasil, denominação que perduraria até a sua extinção, em $1850^{199}$.

O tribunal criado por D. João no Brasil seria composto, por disposição do alvará de 23 de agosto de 1808 em combinação com a carta de lei de 05 de junho de 1788 , por um presidente, 09 (nove) deputados nomeados e um secretário escolhido entre os deputados. Informa WALTER DE MATTOS LOPES que, a despeito da disposição normativa, o tribunal chegou a funcionar com 11 debutados, incluindo o presidente, entre os anos de 1820 e $1821^{200}$.

Suas atribuições diziam respeito a "todas as materias relativas objectos de sua instituição que comprehendem o que é respectivo ao commercio, agricultura, fabricas e navegação; (...)". O tribunal deveria decidir o que the fosse requerido, consultando-se o monarca quando fosse necessário ${ }^{201}$.

Além das funções jurisdicionais, o tribunal ocupava-se das matrículas dos negociantes, da inspeção da aula do comércio, da expedição de certidões e, com o tempo, foi assumindo a qualidade de órgão consultivo da Coroa para os assuntos do comércio,

\footnotetext{
198 “(...) e indispensavel a creação de hum Tribunal Supremo, no qual se examinem, se combinem, e se promovão as materias concernentes á conservação, e augmento do Commercio, da Agricultura, das Fabricas, e da Navegação, cujos objectos, sendo entre si intimamente ligados, e dependentes, devem por tanto ser regidos debaixo de hum só unico, certo, e invariavel systema: (...)”. (Collecção da legislação portugueza de $1775 \quad a \quad 1790, \quad$ Lisboa, Maigrense, 1828, pág. 518, disponível em http://iuslusitaniae.fcsh.unl.pt/ ius/verlivro.php?id_parte=109\&id_obra=73\&pagina=764)

${ }^{199}$ Cfr. LOPES, Walter de Mattos, op. cit. (nota 125), pág. 32.

${ }^{200}$ LOPES, Walter de Mattos, op. cit. (nota 125), pág. 30.

${ }^{201}$ Collecção da legislação portugueza de 1775 a 1790, op. cit. (nota 198), pág 105.
} 
bem como serviu de um canal de aproximação entre a elite local (ou seja, do Rio de Janeiro) e o monarca ${ }^{202}$.

JOSÉ REINALDO DE LiMA LOPES destaca que as atribuições da Junta revelavam caráter de "governo econômico", misturando-se a cargos de natureza administrativa e judiciária. A lógica de sua constituição não corresponde à lógica da separação de poderes, "mas à de uma esfera de atividade dos súditos, o comércio, seja ela sujeito a atividade de governar ou fazer justiça ${ }^{203 "}$.

Por disposição da carta de lei de 05 de junho de 1788, o provimento para o cargo de deputado da Real Junta era vitalício ${ }^{204}$. Desse modo, houve, apenas, uma nomeação de uma diretoria, sem que houvesse, posteriormente, uma renovação sistemática dos quadros diretivos. A substituição dos deputados foi sempre provocada por falecimento, uma vez que não havia possibilidade de exoneração dos seus membros. Essa característica salienta a continuidade e estabilidade da atuação do tribunal, evitando-se, assim, que instabilidades políticas tivessem reflexos na formação do corpo da Real Junta ${ }^{205}$.

Conforme indica WALTER DE MATTOS LOPES, as nomeações desta primeira diretoria evidenciam a composição estamental híbrida. Havia, entre eles, um nobre de grandeza (o presidente, Dom Fernando José de Portugal e Castro, Conde Aguiar), conselheiros, desembargadores, bacharéis e homens de negócios ${ }^{206}$.

Entre aqueles que foram nomeados como deputados, aos 18 de maio de 1809, estava o célebre José da Silva Lisboa, que, à época, ocupava o cargo de Desembargador do Tribunal da Relação da Bahia. A atuação do futuro visconde de Cairu notabiliza-se pela constante e coerente defesa de seus ideias liberais, inspirados por Adam Smith. Isso pode ser notado em seus pareceres que negavam privilégios para instalação de

\footnotetext{
${ }^{202}$ NeVES, Edson Alvisi, op. cit. (nota 191), pág. 180.

203 LIMA LOPES, José Reinaldo. A formação do direito comercial brasileiro: a criação dos tribunais de comércio do império, in Cadernos Direito GV, vol. 4, nº 6, nov. 2007, pág. 15.

${ }^{204}$ Eis a redação da disposição da carta de lei: "E considerando que os Deputados da mesma Real Junta, além dos conhecimentos práticos, devem ser instruidos em Leis, usos, e costumes do Commercio, e Navegação, assim destes Reinos, como das Nações Estrangeiras, cuja instrucção sómente se chega a adquirir com a applicação, e exame dos Negocios occurrentes, e com longa pratica de os tratar, e decidir: Tenho Resoluto, que os ditos lugares sejão vitalicios, para os occuparem os nomeados por Mim, em quanto bem me servirem, e Eu não mandar o contrario: (...)". (Collecção da legislação portugueza de 1775 a 1790, disponível em http://iuslutitaniae.fcsh.unl.pt/ ius/verlivro;php?id_parte=109\&id_obra=73\&pagina=764)

${ }^{205}$ LOPES, Walter de Mattos, op. cit. (nota 125), pág. 97-98.

${ }^{206}$ Idem, Ibidem, pág. 98.
} 
manufaturas no Brasil, posição defendida por ele, calcada em Smith, nas suas Observações sobre a franqueza da indústria e do estabelecimento de fábricas no Brasil ${ }^{207}$.

Assim, nota-se que a estrutura da Real Junta de 1808 era idêntica àquela da Real Junta pombalina de 1755, com as reformas do período mariano, em 1788. No entanto, embora a forma continuasse a mesma, o "novo" tribunal evidencia uma nova coalizão de forças sociais advinda após a transferência da Família Real, com os "homens de negócios" participando, efetivamente, na construção do Estado e não sendo tal construção mera transmigração do Reino de Portugal para os trópicos ${ }^{208}$.

EDSON Alvisi NeVES destaca, neste sentido, que as principais reivindicações dos negociantes foram atendidas em alguns dos mais importantes diplomas legislativos da primeira metade do século XIX, como a Reforma Tarifária de 1844, a Reforma Monetária de 1846, a Lei de Terras, a Lei Eusébio de Queiroz e o Código Comercial, todos de 1850, o que revela, ainda na opinião do autor, como os negociantes foram integrados no projeto centralizador do tempo Saquarema ${ }^{209}$.

§3 - Consequências jurídicas. Vimos, nos parágrafos acima, que a abertura dos portos resultou no incremento do comércio na ainda não emancipada colônia de Portugal, o Brasil. Ao mesmo tempo, vimos a ascensão de uma nova elite - os homens de negócios - que encontram na Real Junta de Comércio criada em 1808 um aparato burocrático capaz de colocá-los em contato imediato com a monarquia e ter seus reclamos atendidos.

Um problema se configurava, no entanto. Como a colônia estava alienada da administração do comércio (vide 2.2.3, $2^{\circ}$, supra), a legislação portuguesa especificamente mercantil era rala e esparsa e, por conta do regime de exclusivo metropolitano, não havia um sólido direito consuetudinário referente às relações

${ }^{207}$ Uma interessante análise sobre esta obra pode ser encontrada em ARRUDA, José Jobson de Andrade; Novais, Fernando António. Prometeus e Atlantes na forja da nação, in SiLva LisBoA, José da. Observações sobre a franqueza da indústria, e estabelecimento de fábricas no Brasil, Brasília, Senado Federal, 1999 (agora in SILVA, Francisco Ribeiro da et ali (org.). Estudos em homenagem a Luís António de Oliveira Ramos, Porto, FLUP, 2004).

Sobre os pareceres de José da Silva Lisboa enquanto deputado da Real Junta, veja-se LoPES, Walter de Mattos, op. cit. (nota 125), págs. 145-171; também KIRSCHNER, Tereza Cristina, José da Silva Lisboa, Visconde de Cairu: itinerários de um ilustrado luso-brasileiro, Belo Horizonte, Alamada, 2009, págs. 161167.

${ }^{208}$ LOPES, Walter de Mattos, op. cit. (nota 125), pág. 33. O autor acrescenta: "Mesmo que mantida a forma, o 'rosto humano' do Tribunal ganhara novas feições e interesses". (Idem, Ibidem, loc. cit)

${ }^{209}$ NEVES, Edson Alvisi, op. cit. (nota 191), pág. 48. 
comerciais, onde encontrar o direito aplicável a uma classe de relações que vinha crescendo e tendia a crescer ainda mais? Em resumo, o problema a ser enfrentado pelo aparato estatal português instalado no Brasil - principalmente pelos deputados da Real Junta - seria de estabelecer qual o direito aplicável às causas mercantis no Brasil ${ }^{210}$.

Com fundamento no $\S 9^{\circ}$ da Lei de 18 de agosto de 1769 (Lei da Boa Razão), combinado os Estatutos da Universidade de 1772 (Livro II, título V, Capítulo I, $\S 16)$, que autorizava a aplicação da legislação estrangeira para decidir causas que versassem sobre política, economia, comércio e navegação, passou a ser corrente a aplicação de diplomas estrangeiros para resolução de demandas mercantis no Império lusobrasileiro. Como já vimos (cap. 1, item 1.2.2, §3º), o Direito Civil brasileiro safou-se, em grande medida, deste sistema de integração de lacunas apontado pela Lei da Boa Razão e pelos Estatutos da Universidade de Coimbra de 1772, o que lhe conferiu caráter conservador mesmo após a sua codificação. O Direito Mercantil brasileiro, ao contrário, sofreu em medida mais elevada a influência desta metodologia de integração de lacunas e, com isso, viu-lhe penetrar de maneira mais decisiva as inovações contidas nos códigos de índole jusracionalista, promulgados por nações estrangeiras.

Antes mesmo do advento dos Estatutos pombalinos, a Lei da Boa Razão já era utilizada como fundamento para serem declarados revogados alguns dispositivos das Ordenações Filipinas que não se coadunavam com a prática mercantil moderna. É possível apontar, assim, que a disposição do mencionado $\S^{\circ}$ do diploma não foi ignorada pelos tribunais. Bem ao contrário, teve importante aplicação na prática decisória.

A título exemplificativo, veja-se o Assento da Casa da Suplicação de 23 de novembro de 1769 que confirma a revogação do Título LIX do Livro III das Ordenações Filipinas quanto aos comerciantes, em vista da aplicabilidade, para a matéria, da legislação da Europa culta e polida, mais favorável ao tráfico comercial. Dispunha o Título LIX do Livro III das Ordenações que qualquer negócio jurídico - firmado por qualquer pessoa de direito público ou de direito privado, versando sobre "bens de raiz", cujo preço passasse de

210 J.X. CARVAlHO DE MENDONÇA aduz que, até então, tinha-se um direito comercial ligado à tradição de um ramo do direito empírico, exatamente como se destacara do direito romano comum, que se formara sem influência das escolas científicas; além de que, o comércio interno no Brasil apresentava-se muito "acanhado e mesquinho" (Cit. (nota 21), pág. 73). 
quatro mil réis, ou, sendo coisas móveis, o valor ultrapassasse sessenta mil réis -, apenas teria validade caso fosse lavrado o instrumento público por tabelião ${ }^{211}$.

O referido assento reconhecia que são muitas as dificuldades acarretadas pelo dispositivo das Ordenações para o tráfico mercantil, declarando-se derrogada aquela disposição aos mercadores e homens de negócio: "Se assentou uniformemente, que a dita Ordenação do Liv. 3. Tit. 59 não podia, nem póde ter alguma applicação aos sobreditos Mercadores, e Homens de Negocio, e que as suas obrigações, procurações, e fórmas dellas, não havendo sido tractadas, reguladas, e decididas pelas Leis deste reino, se devem somente regular pelas Leis Maritimas, e Comerciaes da Europa illuminada, pelo Direito das gentes, e Costumes louvavel e geralmente praticadas pelas Nações comerciantes da mesma Europa, como já se acha expressa, e litteralmente determinado pelo $\$ 9^{\circ}$ da Providentissima Lei de 18 de Agosto deste presente anno (...)" ${ }^{212}$.

Nota-se, portanto, que o assento em comento confirma, com fundamento na Lei da Boa Razão, a revogação da norma contida nas Ordenações Filipinas, Livro III, Título LIX, apenas em relação aos mercadores. Os negócios de Direito Civil continuariam regrados pelas Ordenações.

Cremos ser possível, com isso, concluir que a modernização do Direito Comercial em Portugal, com seus naturais reflexos no Brasil, não passou por uma reforma legislativa específica, mas foi alavancada pelo $\S 9^{\circ}$ da Lei de 18 de agosto de 1769 , pelo

\footnotetext{
${ }^{211}$ O título tinha a seguinte epígrafe: "Das provas, que se devem fazer per scripturas publicas”. Eis a redação referida disposição: "Todos os contractos, avenças, convenças, pactos, composições, compras, vendas, escaimbos permutações, dotes, arras, doações, stipulações, promissões, aforamentos, arrendamentos, emprestimos, encomendas, guardas, depositos e quaesquer outros contractos de qualquer natureza e condição que sejam, assi perpetuos, como a certo tempo, e per qualquer nome de Direito, ou costume de nossos Reinos nomeados, ou sejão de maior, ou menor condição, ou de maior, ou menor força e virtude, que estes aqui declarados, que quaesquer pessoas, assi publicas, como privadas, Concelhos, Communidades, Collegios, Confrarias, e assi homens, como mulheres, de qualquer stado, e condição que sejam, fizerem, e affirmar quizerem em nossos Reinos e Senhorios, se forem sobre bens de raiz, e a quantia da obrigação passar de quatro mil réis, ou se forem sobre bens e cousas moveis, e a quantidade da divida passar de sessenta mil réis: e bem assi todas as pagas, quitações, soluções, renunciações transações, remissões, divisões, e partições de heranças, e de quaesquer outros bens, revogações spaços de dívidas e de quaesquer obrigações, pacto, ou convença de não demandar, e outras quaesquer innovações dos ditos contractos, ou firmidòes, ou de outros, de qualquer natureza e condição que sejam, assi reaes, como pessoaes, quer porá razão de feitos crimes, quer civeis, que passarem das ditas quantias de sessenta mil réis nas cousas moveis, e de quatro mil réis no bens de raiz, sejam firmados e feitos por scripturas per Tabelliães públicos, ou Scrivão authentico, que para isso tenha autoridade, perante testemunhas, ou per nossas Cartas. E em taes casos, em que segundo disposição desta lei se requere scriptura publica, não será recebida prova alguma de testemunhos: e se forem recebidas testemunhas, tal prova será nenhuma, e de nenhum effeito, posto que a parte o não opponha".

${ }^{212}$ Collecção chronologica dos assentos das casas da supplicação e do cível, Coimbra, Real Imprensa da Universidade, 1786, págs. 472-474.
} 
$\S 16$ dos Novos Estatutos da Universidade de 1772 e pela consequente aplicação direta da doutrina e legislação internacionais.

Especificamente no que se refere ao Brasil, informa CARVALHO DE MendonçA: "O Código Comercial francês, de 1807, cuja irradiação era intensa pelo mundo inteiro, e, mais tarde, os Códigos Comerciais da Espanha de 1829 e de Portugal de 1833, aliás, sem a autoridade do primeiro, passaram a constituir a verdadeira legislação mercantil nacional ${ }^{213}$,.

Os debates parlamentares ocorridos em torno da aprovação do Código Comercial brasileiro dão testemunho da medida a que chegou a utilização da legislação estrangeira no território nacional. O deputado Pereira da Silva, na sessão de 30 de agosto de 1843, travou debate com o deputado Urbano Sabino Pessoa, o primeiro advogando pela urgência da discussão em bloco do projeto naquele mesmo ano de 1843, enquanto o segundo, sem negar a urgência do assunto, propunha o adiamento da discussão para o ano seguinte para que se pudesse, com a devida calma, ler e formar julgamento sobre o projeto em trâmite. Pereira da Silva, na ocasião, proferiu as seguintes palavras:

"E qual é a legislação que temos commercial? A lei de 18 de Agosto de 1769, que, com alguns alvarás, dispõe pequenas medidas e que manda em todos os casos omissos reger-se pela legislação dos povos mais cultos. Ora, quasi todos os casos são omissos, e os que o não são já as luzes do seculo presente prescreverão; as nações estrangeiras pelos seus hábitos e costumes têm differenças mais ou menos sensiveis em suas leis, e o que acontece? É que cada magistrado, que tem de dar uma sentença sobre questões commerciaes, dá como lhe parece. Não ha homogeneidade, não há conhecimento fixo e determinado de todos os estylos e usos das praças de commercio, que devem influir nos julgamentos, de modo que não são unanimes os magistrados nos julgamentos. As questões dos seguros, das preferencias de credores, dos contractos de riscos, das quebras e banca-rotas fraudulentas, não tendo legislação, são decididas e julgadas tão differentemente, quantos são os magistrados que tomão dellas conhecimento. O codigo criminal do imperio define o crime de banca-rota aquelle que fôr assim qualificado pelas leis commerciaes; não há leis commercciaes a rsepeito; nas das nações

\footnotetext{
213 CARvalho DE MENDONÇA, José Xavier, op. cit. (nota 21), pág. 74. Corrobora José ReinAldo DE LiMA LOPES, em recente estudo sobre a jurisdição comercial ao longo da história de Brasil e Portugal, a informação prestada por J.X. CARVAlHo DE MEndOnÇA: "Quanto às fontes do direito comercial, estavam os juízes autorizados, pela lei de 18 de agosto de 1769 (Lei da Boa Razão) a valer-se da legislação estrangeira, sendo comum, como se verá adiante no curso do debate parlamentar, que eles se valessem do código francês (de 1807), do código espanhol (de 1829) e do código português (de 1833)" (A formação, op. cit. (nota 203), pág. 19). No mesmo sentido, ainda, Alfredo Russell: "O código francês de 1807 e os da Espanha de 1829 e de Portugal de 1823 passavam assim a constituir a legislação mercantil brasileira” (Cit. (nota 167), pág. 55).
} 
estrangeiras ha differenças em banca-rotas fraudulentas e banca-rotas com culpa; a experiencia tem mostrado que dessa falta de legislação resulta que o crime de banca-rota não existe no Brazil"214.

A partir do discurso transcrito, nota-se que a aplicação da legislação estrangeira causa transtornos e insegurança nas decisões.

Também na sessão de 02 de julho de 1845, o Deputado Junqueira afirma que "os tribunaes se têm regulado até agora pela legislação subsidiaria das nações civilisadas, quer do código commercial francez, quer da Hespanha, e ultimamente do código commercial portuguez ${ }^{215}$ ".

Mas não apenas desses códigos estrangeiros valeu-se o tribunal da Real Junta para encontrar o regramento mercantil aplicável. Ao lado dessas fontes legislativas, os Princípios de Direito Mercantil, de JosÉ DA SILVA LISBOA operaram como subsídio à legislação. Como informa CÂNDIDO MENDES DE ALMEIDA, a obra de LisBOA era, à sua época, única em língua portuguesa, "de indisputavel authoridade em todos os domínios da Monarchia Portugueza, como o assegura Ferreira Borges", e fez as vezes de Código Comercial $^{216}$.

Além dos referidos Princípios, José DA SiLVA LISBOA também contribuiu para a identificação do direito mercantil aplicável por meio da elaboração de um opúsculo, cuja primeira edição data de 1832, chamado Regras da Praça ou Bases de regulamento commercial conforme aos novos codigos de commercio da França e Hespanha, e á legislação pátria com opportunas modificações de estatutos e usos das nações civilisadas $^{217}$.

\footnotetext{
${ }^{214}$ Anais da Câmara dos Deputados, sessão de 30 de setembro de 1843.

${ }^{215}$ Anais da Câmara dos Deputados, sessão de 02 de julho de 1845.

${ }^{216}$ Mendes DE Almeida, Cândido. Introdução a SILVA LisboA, José da. Princípios de direito mercantil e leis de marinha divididos em sete tratados elementares, contendo a respectiva legislação patria, e indicando as fontes originaes dos regulamentos maritimos das principaes praças da Europa, tomo I, $6^{\mathrm{a}}$ ed. Rio de Janeiro, Acadêmica, 1874, págs. pág. VII.

É o próprio FERREIRA BORGES quem atesta terem as obra de SILVA LisBOA servido de Código Mercantil para Portugal. As palavras do ilustre comercialista português estão transcritas nas Regras da Praça do próprio Silva LisboA, consultada na forma de anexo à edição dos Princípios de Direito Mercantil organizada por CÂNDIDo Mendes DE AlmeidA: “(...): provão que o primeiro Jurisconsulto Commercial que escreveo em nossa linguagem o Sr. José da Silva Lisbôa, Visconde de Cayrú, o elogia; este venerando Jurisconsulto, cujas obras forão Codigo Mercantil para Portugal, até á publicação do Codigo Commercial Portuguez (...)". (Princípios, op. cit. (nota 216), tomo II,, pág. 956).

${ }^{217}$ Silva LisBOA, José da. Regras, op. cit. (nota 216), págs. 929-956.
} 
A intenção do autor ao elaborar as Regras da Praça era a de suprir algumas incertezas quando ao direito positivo aplicável a alguns assuntos por meio da organização de um elenco de regras práticas extraídas, sobretudo, dos Códigos Comerciais da França e da Espanha, e também dos usos das "nações civilizadas". A ideia do autor era que o seu escrito fosse utilizado nas Aulas do Comércio, além de auxiliar o corpo mercantil com uma sinopse de regras "para a legitimidade e segurança de suas transacções de Praça (... $)^{218}$.

As obras do Visconde de Cairu podem, também, ser consideradas portas de entrada para inovações no Direito Comercial brasileiro, não só por se basearem em escritores e na legislação do jusracionalismo e do movimento codificador, mas pela própria formação intelectual de seu autor. LiSBOA realizou seus estudos de nível superior na Universidade de Coimbra com o currículo recém reformulado pelos Estatutos de 1772. Sua formação intelectual deixa entrever a influência Iluminista ${ }^{219}$.

§4- Impacto na codificação do Direito Comercial brasileiro. Vimos, nos parágrafos acima, que após a abertura dos portos tivemos a ascensão de uma nova classe os homens de negócios - capaz de influir no aparato administrativo e nas tomadas de decisão da Coroa portuguesa instalada no Brasil.

Além disso, a mesma classe teve um aparelho burocrático capaz de levá-la diretamente à consecução de seus interesses políticos. Tal aparelho era a Real Junta do Comércio, Agricultura, Fábricas e Navegação.

Os interesses dos homens de negócios não estavam de tudo alienados aos da tradicional classe dos proprietários de terras, afinal eram, justamente, os proprietários aqueles que tinham condições de absorver os produtos do comércio. No entanto, a classe comerciante tinha valores diferentes e uma visão de mundo diversa daquela da classe tradicionalista. Mais que isso, tinha condições de levar para o plano da decisão política

\footnotetext{
${ }^{218}$ Idem, Ibidem, pág. 931 e 948.

${ }^{219}$ José da Silva Lisboa teria chegado a Portugal em 1773 para dar prosseguimento aos seus estudos. Seu pai, Henrique da Silva Lisboa, era operário em obras, e o futuro Visconde pôde ir à Universidade pelo apoio do bispo de Coimbra, D. Francisco de Lemos de Faria Pereira Coutinho. Apesar das origens humildes, Henrique da Silva Lisboa conseguiu enviar à Coimbra quatro de seus filhos.

Sobre a formação de Cairu, TEREZA CRISTINA KIRSCHNER aduz: "a formação de Silva Lisboa insere-se, portanto, nesse contexto de reformas provenientes de uma mudança de percepção do universo jurídico. Além de cursar a faculdade de Cânones e as disciplinas obrigatórias no curso de Leis, Lisboa frequentou, simultaneamente, o curso de Filosofia, onde assimilou a importância da filosofia natural para a exploração dos recursos do império português". (Cit. (nota 207), pág. 37).
} 
seus valores e visão de mundo. Este dado, certamente, afetou o caráter da Codificação do Direito Comercial brasileiro.

Enquanto os proprietários de terras podiam ter, no plano jurídico, seus interesses atendidos pelas disposições das já antigas Ordenações Filipinas, a classe mercante não podia se contentar com esse regramento "pesado e abstruso", nas palavras de J.X. CARVALHO DE MENDONÇA ${ }^{220}$. Havia urgência na confecção de um conjunto de regras que atendesse às demandas da classe comerciante. Tanto é verdade que, antes mesmo que tivéssemos a renovação do regramento do Direito Civil, tivemos um Código Comercial, ainda que a Carta Constitucional de 1824 contivesse promessa solene de codificação do Direito Civil, sem menção ao Direito Comercial.

Passamos, a seguir, a uma breve exposição a respeito do primeiro processo de codificação do Direito Comercial nacional ${ }^{221}$.

\section{2 - A codificação do Direito Comercial brasileiro.}

\subsection{1 - A primeira tentativa: José da Silva Lisboa.}

\section{$\$ 1^{\circ}$ - A consulta a Real Junta e a escolha de Cairu para elaboração de um}

projeto de Código Comercial. Como já vimos (ver item 2.1.3, $\S 3^{\circ}$, supra), após a abertura dos portos brasileiros assiste-se ao incremento de uma nova classe de relações para a qual não havia regramento específico suficiente ou costumes que fossem aplicáveis - as relações de Direito Mercantil.

A solução provisória encontrada foi a aplicação da legislação subsidiária às Ordenações que, no caso do Direito Mercantil, por disposição do $\S 9^{\circ}$ da Lei da Boa Razão combinada com a do $§ 16$ dos Estatutos da Universidade de Coimbra de 1772, era regramento contido nos códigos das nações cultas e polidas da Europa.

${ }^{220}$ CARvalho de MendonÇA, José Xavier, op. cit. (nota 21), pág. 73.

${ }^{221}$ Dissemos "primeiro processo de codificação" em vista do projeto de Código Comercial de autoria do professor FÁBio UlHOA COELHO em trâmite no Congresso Nacional (v. supra, introdução $\S 1^{\circ}$ ). 
No entanto, não se descuidou da preocupação de confeccionar um conjunto de regras próprio para o Direito Comercial luso-brasileiro e as tentativas de codificação começaram anos antes da própria independência política do Brasil.

Com efeito, aos 27 de julho de 1809, a Real Junta aprovou uma resolução para levar ao Príncipe Regente a sugestão de nomear José da Silva Lisboa para elaborar um projeto de Código Comercial.

Em 1826, o então Barão de Cairu apresenta um plano de Código Comercial acompanhado de um relatório preliminar. Sobre a necessidade da codificação, lê-se no relatório:

“(...)he claro o interesse publico de haver hum Código de Commercial, que seja o Manual de todas as classes, que diariamente fazem tratos com Negociantes e navegantes, para facilidade e segurança de seus ajustes, e tambem para libertar-se a nação Brasileira da necessidade, e indecencia de mendigar a Lei de viver, e a decisão de seus pleitos, de Códigos estrangeiros $^{222,}$.

O autor do plano, após enumerar suas fontes doutrinárias e legislativas, adverte que "he impraticável originalidade substancial em Legislação de Commercio", pois deve ser o código fundado nos usos e costumes das praças. $\mathrm{O}$ autor, então, expõe a divisão em livros que pretendia atribuir ao seu projeto: haveria cinco livros, sendo primeiro sobre a liberdade de comércio, contratos comerciais terrestres e marítimos; em seguida, haveria o livro sobre os navios, negociantes e navegantes; o terceiro livro trataria dos tribunais comerciais, dos órgãos administrativos do comércio e da falência; o quarto livro trataria da polícia dos portos e mares; o quinto e último livro regulamentaria a proteção da marinha, renda, indústria e saúde pública.

O projeto de Cairu não teve prosseguimento e é o próprio autor quem nos explica os motivos:

“Quando, em 1809 se creou o Tribunal do Commercio, em Resolução de sua consulta se me deu a Commissão de organisar hum Codigo de Commercio.

\footnotetext{
${ }^{222}$ Silva Lisboa, José da. Plano do código de comércio, in Neves, Edson Alvisi, op. cit. (nota 191), pág.
} 366. 
Essa obra herculea muito excedia ás minhas forças; além de requerer superior capacidade, exigia tempo, descanço, auxilio, pratica de negocios, e vigor de idade.

Tudo isto me faltou.

(...)

Depois da declaração da Independencia do Imperio fui encarregado por ordem superior de escrever a Historia do Brazil.

Havendo apresentado a parte $1^{\text {a }}$, pedi permissão de pausa, para continuar o trabalho do Codigo, apresentando hum plano á Secretaria de Estado dos Negocios do Imperio: e posto fosse deferida favoravelmente a minha supplica, recommendou-se-me com tudo que não me esquecesse da ordenada principal Chronica dos successos dignos de memória, occorridos de 26 de Fevereiro de 1821 em diante, ao que satisfiz quanto pude, relatando o período decorrido desde aquella epoca até o dia 12 de Outubro da Acclamação do então Principe Regente do Brazil $^{223}$,

Não tendo o êxito esperado na confecção do projeto de Código Comercial, José da Silva Lisboa oferece ao público as Regras da Praça como "hum Esboço de Provisorio Regimento do Commercio, em desempelho da Obrigação Official ${ }^{224, "}$.

Portanto, a primeira tentativa de codificação do Direito Comercial brasileiro terminou sem que houvesse um verdadeiro projeto de código. No entanto, logo em seguida, com o país já independente, tiveram prosseguimento os trabalhos que resultaram no Código de 1850.

\subsection{2. - A proposta de Diogo Ratton}

§1- A proposta de adoção do Código Comercial francês. A falta de uniformidade nos julgados e a ausência de um regramento mercantil que desse segurança às relações travadas nas praças de comércio faziam-se sentir de forma decisiva. Chegou-se ao ponto de, no ano de 1821, propor-se a adoção do Código Comercial francês como legislação mercantil para todo o Reino Unido de Portugal, Brasil e Algarves.

${ }^{223}$ Silva LisboA, José da. Regras da praça, op. cit. (nota 216), pág. 932.
${ }^{224}$ Silva LisboA, José da. Regras da praça, op. cit. (nota 216), pág. 932. 
O autor da proposta foi Diogo RATTON, que publicou, em Lisboa, em outubro do referido ano, suas Reflexões sobre o codigo mercantil, sobre o tribunaes do commercio e sobre navegação mercantil, atendendo, segundo o próprio autor, ao pedido de pessoas de sua amizade para que continuasse a publicar suas reflexões sobre objetos de comércio $^{225}$.

No seu opúsculo, o autor propõe:

"Por ser $\operatorname{logo}$ de muita urgência o termos hum Codigo mercantil; e para não haver demora, nem se perder tempo em elle se realizar, lembro ao Soberano Congresso o adoptar aquelle, que hoje he conhecido por melhor, qual he o que se acha em pratica em França, alli estabelecido por Napoleon ${ }^{226,}$.

\$2- A reação do Visconde de Cairu. JOSÉ DA SILVA LISBOA manifesta-se sobre semelhante ideia nas Regras da Praça. Para ele, não havia sentido em impor que as soluções para os casos mercantis tivessem de ser extraídas do Código Comercial francês, uma vez que, no momento em que escrevia as Regras, já estava em vigência o Código da Espanha, para ele superior ao francês ${ }^{227}$.

${ }^{225}$ RATTON, Diogo. Reflexões sobre o codigo mercantil, sobre o tribunaes do commercio e sobre navegação mercantil, Lisboa, 1821, pág. 1.

${ }^{226}$ Idem, Ibidem, pág. 2.

${ }^{227}$ Silva LisbOA, José da. Regras da praça, op. cit. (nota 216), pág. 935. 


\subsection{3 - A segunda tentativa: o projeto da Comissão extraparlamentar}

da Regência.

$\$^{\circ}$ - Nomeação da Comissão extraparlamentar. Os primeiros passos para a elaboração do Código Comercial foram dados em 1832, quando a Regência nomeou, aos 14 de maio daquele ano, comissão encarregada da elaboração de um projeto de código. A referida comissão foi formada por Antônio Paulínio Limpo de Abreu (depois Visconde de Abaeté), José Antônio Lisboa, Inácio Ratton, Guilherme Midosi e Honório José Teixeira. Honório José não aceitou a nomeação, sendo substituído por Lourenço Westin, cônsul da Suécia.

A comissão foi, em um primeiro momento, presidida por Limpo de Abreu e, em seguida por José Clemente Pereira (1833-1834), depois que o primeiro fora eleito presidente da Câmera dos Deputados, na sessão de 03 de maio de $1832^{228}$.

É notória a ausência na composição da comissão de José da Silva Lisboa. Afirmam alguns que o Visconde de Cairu não foi convidado para colaborar com a elaboração do projeto por razões políticas. No entanto, a justificativa oficial da Regência era de que, contando Cairu com idade já avançada e acometido por enfermidades, não se queria impor-lhe ainda mais obrigações. Para evitar o mal estar causado pela censura levantada por um periódico do Rio de Janeiro, a Regência elaborou uma explicação e um convite para que Cairu concorresse para a confecção do projeto. O Visconde, por sua vez, declinou do convite ${ }^{229}$.

$\$^{\circ}$ - O projeto de Código Comercial. Sob a presidência de Clemente Pereira, a comissão elaborou projeto de código, que foi entregue em 1834, dividido em três

\footnotetext{
${ }^{228}$ CARVAlHo de MendonçA, José Xavier, op. cit. (nota 21), pág. 85.

${ }^{229} \mathrm{O}$ documento que convidava Cairu para compor a comissão estava assim redigido: "Ilmo Sr. A Regência em nome do Imperador: Há por bem significar a V. Exa. que, tendo sido criada uma Comissão de homens probos e inteligentes para organizar o projeto de um Código Mercantil, de que tanto se precisa, deixou V. Exa. de ser convidado para ela, não por quebra de consideração devida à sua grande reputação literária, principalmente em semelhantes matérias, como o mundo sabe; mas porque oprimido por suas habituais enfermidades, receasse a mesma Regência incomodar ainda V. Exa. com o acréscimo de novos trabalhos, além dos de sua ordinária obrigação.

Hoje, porém, certa de que V. Exa., gozando de melhor saúde, e tendo mesmo preparado já alguns trabalhos sobre semelhante Código, se não esquivará de concorrer com suas luzes para a obra de tão geral utilidade, e da qual dependerá a prosperidade do Brasil, me ordena que convide a V. Exa. para que, unido à dita Comissão, a coadjuve como bem permitirem suas forças físicas, no referido serviço, de que se acha encarregada. Deus guarde a V. Exa. Paço, 11 de abril de 1832. José Lino Coutinho”. (in Neves, Edson Alvisi, op. cit. (nota 198), pág. 373)
} 
partes: a primeira, relativa às pessoas do comércio (contratos e obrigações mercantis); a segunda, sobre o comércio marítimo; a terceira, sobre quebras.

A Comissão atesta, na exposição de motivos, que duas ideias principais guiaram a elaboração do projeto: a primeira, que o código deve estar em harmonia com os princípios gerais e com os grandes usos comerciais "que reúnem debaixo de uma só bandeira os povos do novo e velho mundo ${ }^{230}$ "; a segunda ideia é a de que um Código Comercial deve ser bem adaptado às circunstâncias do povo para quem é elaborado ${ }^{231}$.

Para satisfazer a primeira demanda - mais fácil de ser atendida, conforme os redatores -, a Comissão consultou a legislação e doutrina internacionais. Em relação à segunda necessidade - de adaptar as regras às circunstâncias brasileiras -, procurou a Comissão atentar para a "posição especial da falta de conhecimentos theoricos e práticos da sciencia Commercial do paiz", introduzindo no projeto normas que guiassem o comerciante em todos os atos de sua vida comercial. Neste aspecto, desviou-se do sistema de outros códigos, que se limitava a estabelecer normais especiais para o comércio, contando com o regramento do Direito Civil para os aspectos gerais ${ }^{232}$.

Ainda em relação a este aspecto, a Comissão observava que, no tocante aos contratos mercantis, "os melhores Codigos se limitavão a estabelecer as excepções relativas ao Commercio, remettendo-se no mais ás disposições geares dos Codigos Civis respectivos". O projeto, então, se diferenciava da maioria dos códigos, pois, de acordo com a Comissão, convinha dar "aos nossos Comerciantes normas directoras de todos os seus actos mercantis, e attendendo a que as Leis Civis do Imperio são escassas na materia de Contractos, ordenou títulos completos das diversas naturezas de Contractos admissíveis em Commercio $(\ldots)^{233,}$.

\footnotetext{
${ }^{230}$ Projecto do Codigo Commercial do Imperio do Brazil, organisado por huma comissão de negociantes nomeada por sua Magestade Imperial, apresentado à Camara dos Deputados e approvado pelas comissões reunidas de Commercio, Agricultura, Industria e Artes, de Justiça Civil e de Justiça Criminal em 9 de setembro de 1834, Rio de Janeiro, Seignot- Plancher e CIA, 1834, pág. I.

${ }^{231}$ Eis as palavra contidas na exposição de motivos: “(...) hum Codigo de Commercio deve ser redigido sobre os principios adaptados por todas as Nações Commerciantes, e que estejão em harmonia com os grandes usos Commerciaes que reúnem debaixo de uma só bandeira os povos do novo e velho mundo; segundo, que hum Codigo de Commercio de deve ser ao mesmo tempo accomodado ás circunstancias especiaes do povo para quem he feito" (Ibidem, loc. cit).

${ }_{232}$ Ibidem, pág. III.

${ }^{233} \mathrm{Ibidem}$, pág. V.
} 
$\$^{\mathbf{0}}$ - O trâmite legislativo do projeto ${ }^{234}$. Não tardou, como vimos, para que a comissão encarregada da elaboração do projeto se desincumbisse do dever. No entanto, entre a entrega do projeto e a promulgação do código, em 1850, transcorreram 16 anos.

Em agosto de 1834, o projeto foi enviado à Câmara dos Deputados e passou a ser analisado por uma comissão formada a partir da reunião das comissões de comércio, agricultura, indústria e artes e de justiça. Aos 09 de setembro do mesmo ano, a comissão assinou parecer unânime em que se aduzia ser o projeto "uma obra senão perfeita, pelo menos de muito merecimento ${ }^{235}$,.

Na sessão de 20 de junho de 1835, abriu-se a discussão em que se pronunciaram o Visconde de Goiana e Carneiro Leão sobre a necessidade de emendar o projeto, que, segundo eles, não pode podia ser aprovado tal como se achava. O projeto foi, então, confiado a uma comissão mista entre deputados e senadores, por resolução da Câmara na sessão de 23 de junho de $1835^{236}$.

A comissão mista foi formada pelos senadores Marquês de Maricá, João Antônio Rodrigues de Carvalho e Francisco de Paula e Sousa, e dos deputados Visconde de Goiana, Manuel Joaquim do Amaral Gurgel e João José Moura Magalhães. Pela comissão mista foi apresentado parecer em 11 de outubro de 1835, em que se julgava que “o Código de Comércio do Brasil, emendado como agora se acha, nada tem a invejar a legislação da França, da Inglaterra, de Portugal e de Espanha; ele apresenta em um todo sistemático o que há de melhor nesses Códigos, modificadas as suas doutrinas segundo os espíritos mais entendidos nessas matérias e adaptadas às circunstâncias do Brasil”. A comissão ressaltava, ainda, as contribuições de José Clemente Pereira e de Lourenço Westin $^{237}$.

A praça do comércio do Rio de Janeiro apresentou ao corpo legislativo um projeto de emendas em 1836. Em 1837, apresentou o exame sobre o comércio marítimo e, em 1838, a parte final dos seus trabalhos, sobre as quebras.

\footnotetext{
${ }^{234}$ Para este parágrafo, seguiremos de perto J.X. CARVAlHo DE MEndonÇA, cit. (nota 21); e, WALdEMAR MARTins FerreirA, cit. (167); MAChAdo D’ Oliveira, Brasilio Augusto. O Codigo commercial do Brasil: subsídios históricos de sua formação, in Revista da Faculdade de Direito de São Paulo, vol. XVII, 1909.

${ }^{235}$ Cfr. CARvalho De MendonçA, José Xavier, op. cit. (nota 21), pág. 87. O parecer em questão está transcrito por MACHADO D’ OLIVEIRA, Brasilio Augusto, op. cit. (nota 231), pág. 22.

${ }^{236}$ CARVAlHO DE MENDONÇA, José Xavier, op. cit. (nota 21), pág. 87

${ }^{237}$ CARVAlHo DE MENDONÇA, José Xavier, op. cit. (nota 21), pág. 87.
} 
O projeto de Código Comercial ficou, a partir de então, um pouco esquecido dos legisladores. Entretanto, foi objeto de constantes debates pelas classes interessadas que fizeram chegar ao legislativo suas demandas pela urgente aprovação do projeto. Chegaram à Câmara dos Deputados, no ano de 1843, manifestações da Assembléia Provincial da Bahia, da Associação Comercial de Pernambuco, da Comissão da Praça e Negociantes do Rio de Janeiro, além daquelas de membros da própria câmara ${ }^{238}$.

Ante as insistências, nomeou-se, em 1843, nova comissão mista de deputados e senadores. Os trabalhos, todavia, foram novamente interrompidos em 1844 pela dissolução da Câmara.

Após a reabertura da Câmara dos Deputados, mais uma vez, uma comissão foi nomeada na sessão de 22 de janeiro de 1845, encarregada de rever o projeto. Aos 28 de junho do mesmo ano, foi lido o parecer e a discussão na câmara foi retomada em 02 de julho $^{239}$. Quinze dias depois (17 de julho), a redação foi aprovada e o projeto seguiu para o Senado $^{240}$.

${ }^{238}$ Idem, Ibidem, pág. 89.

${ }^{239}$ Por ser documento importante e que resume em parte os principais debates que tiveram lugar na Câmara dos Deputados em torno do Código de 1850, inclusive quanto ao modo de discussão e aprovação, transcrevemos o parecer da comissão de 1845 em sua integralidade: "A commissão especial encarregada de examinar o projecto do codigo commercial, apresentando a esta augusta camara dos deputados em sessão de 1843, o revio e comparou com os codigos commerciaes mais conhecidos, e observa que no projecto se compilou a legislação commercial dos paixes cultos com as modificações que nossos usos e costumes aconselhão. Cumpre aqui dizer que o projecto actual comparado com o primeiro projecto redigido em 1843 está muito melhorado com os trabalhos da commissão mixta de 1835, da commissão da praça do commercio, e de alguns jurisconsultos e commerciantes que forão consultados, e que de boa vontade concorrêrão para esta obra importante, e ultimamente com a revisão da commissão mixta de 1843; e comquanto pense a commissão que de alguma perfeição é ainda susceptível o novo projecto, julga que póde ser adoptado sem grave inconveniente na sua execução, aguardando da pratica de suas disposições os melhoramentos que a experiencia tornar indispensáveis; porquanto cada dia se faz mais imperiosa a necessidade dar ao paiz um systema de legislação commercial, para evitar a decadência e ruína do nosso commercio, que luta com a incerteza das regras, que regem as questões mercantis decididas até o presente pelo arbítrio dos julgadores, e mediante processos impróprios e inefficazes; o projecto apresenta esse systema, prescreve essas regras, estabelece os tribunaes e juízos commerciaes, e se na ordem do juízo das causas de commercio não apresenta todo o desenvolvimento que era para desejar, dá ao menos os principios geraes, sobre os quaes, feito o regulamento do governo, preencherá o fim. Parece á primeira vista que a ordem do juízo nestas causas não deve ficar a arbitrio de um regulamento, e a commissão lembrou-se de apresentar maior desenvolvimento ao cap. $2^{\circ}$ da administração da justiça em materias commerciaes, adoptando grande parte das disposições do liv. $3^{\circ}$ do codigo de Ferreira Borges, que são mui applicaveis ao Brazil, mas desistio desse trabalho, não só porque se presuade que o governo, a quem se dá a faculdade de fazer o regulamento, o consultará, como porque a experiencia de nossos commerciantes e jurisconsultos concorrerá para se adoptarem as mais adequadas disposições, que terão de ser approvadas pelo corpo legislativo, depois de reconhecidos os seus resultados práticos.

"Quanto á maneira por que deve discutir o projecto do codigo commercial, a commissão examinou o que a tal respeito tinha anteriormente decido esta augusta camara, e achou que as commissões reunidas propuzerão em 1843 que fosse discutido em globo, approvando-se ou rejeitando-se, e que a mesa, examinando esta proposição, foi de parecer que o projecto do codigo commercial tivesse uma só discussão correspondente á 
No Senado, debateu-se, na sessão de 09 de setembro de 1845 , se deveria ou não ser discutido em globo o projeto. No entanto, a requerimento do senador Rodrigues Tôrres, resolveu-se adiar a discussão para o ano seguinte.

Entre 1846 e 1848, o projeto foi discutido três vezes no Senado e recebeu muitas emendas. Aos 20 de setembro de 1848, o projeto é devolvido à Câmara e, quase dois anos depois, todas as emendas foram aceitas na sessão de 06 de março de 1850. Enviado para sanção aos 02 de maio, o projeto foi, finalmente, promulgado como Lei $\mathrm{n}^{\circ}$ 556 , de 25 de junho de 1850.

terceira, nos termos do art. 135 do regimento, dispensando-se para esse fim a disposição do art. 127, e em sessão de 30 de Agosto de dito anno foi approvado este parecer.

"Em consequencia desta resolução, entrando em discussão o projecto, na sessão de 18 de Setembro de 1843, ficou adiado até a futura sessão.

"A commissão especial, considerando que a resolução da camara, tomada sobre valiosos motivos, deve hoje ser observado na discussão do projecto, é de parecer que continue a discussão do mesmo projecto, adiada na sessão de 1843.

"Paço da camara dos deputados, em 28 de Junho de 18430 J. Antão. - Paulo Barbosa. - S. e Olveira." (Anais da Câmara dos Deputados, sessão de 28 de junho de 1845)

${ }^{240}$ Cfr. CARvalho De MendonçA, José Xavier, op. cit. (nota 21), pág. 92. 


\section{Capítulo 3 - A teoria da causa subjetiva no âmbito do tratamento legislativo dispensado aos contratos mercantis pelo Código Comercial brasileiro.}

Plano do capítulo - Neste ponto, pretendemos analisar o rumo tomado pela codificação do Direito Comercial a partir de um problema concreto: a inserção, no art. 129, inc. 3 do regramento sobre a causa no direito das obrigações conforme o modelo francês, cunhado, principalmente, por ROBERT JOSEPH POTHIER e acolhido no art. 1108 do Code Civil de 1804.

Preliminarmente, visando a demonstrar de que modo a interpretação de POTHIER se distancia da tradição romanística que os precede, lançaremos um breve olhar sobre as fontes romanas e as interpretações que sobres elas se fizeram. Em seguida, veremos qual o pensamento informa o regramento adotado pelo Código Civil francês, procurando caracterizar a doutrina sobre a causa inserta no célebre diploma.

Em seguida, verificaremos de que forma o regramento do Código Comercial brasileiro e suas interpretações doutrinária e jurisprudencial conformam-se á concepção francesa.

Pretende-se, com isso, demonstrar um aspecto concreto da penetração de ideias provenientes do período jusracionalista no Direito Privado brasileiro, revelando-se, assim, o caráter menos conservador do nosso Direito Comercial, se comparado ao Direito Civil. Trata-se de um importante aspecto da historiografia jurídica nacional, em certa medida negligenciado.

Nota-se que o regramento do Código Comercial, no que se refere ao problema da causa, é sensivelmente diverso daquele que sempre fora empreendido pelo Direito Civil nacional, situação esta que só foi modificada pela unificação do direito das obrigações pelo Código Civil de 2002, o que revela que, por mais de século e meio, tivemos duas tradições jurídicas - pelo menos no tocante ao problema da causa convivendo lado a lado dentro do Direito Privado brasileiro. 


\section{1 - Breve nota a respeito das fontes justinianéias e do pensamento medieval em torno do problema da causa.}

\subsection{1 - Alguns significados do termo causa nas fontes justinianéias.}

\section{$\$ 1^{\circ}$ - Emprego do termo em sentidos diversos a consequente falta de}

teorização e sistematicidade da teoria da causa no Direito Romano. EMILIO BETTI ensina que causa assume diversos sentidos no discurso dos juristas romanos. Tais significados podem ser reduzidos à ideia de circunstância ou posição condicionante ${ }^{241}$. Também GIUSEPPE GROSSO afirma não ser conveniente uma pesquisa terminológica a respeito de causa no âmbito do Direito Romano, pois, nas fontes, a palavra é usada nos mais variados significados $^{242}$.

Entretanto, o próprio BETTI indica que dois significados técnicos assumem especial importância: o primeiro deles, o que trata causa como hipótese de fato (suporte fático abstrato) cuja composição provoca a incidência da norma e a criação de uma situação jurídica (que o autor chama, genericamente, de actio) - causa está, neste sentido, em oposição a res, que indicaria o suporte fático concreto, a realização de um evento que compõe a hipótese de fato.

O segundo sentido refere-se à causa como circunstância determinante de um comportamento, seja como fim a atingir ou como um título para realizar uma atribuição. Vê-se, então, causa empregada como situação objetiva em que o comportamento de uma pessoa se enquadra.Tal comportamento atinge sua justificação (iusta causa), ora no sentido negativo de excluir uma responsabilidade em relação a outro sujeito, ora no sentido

${ }^{241}$ BetTI, Emilio. Causa - diritto romano, in Novissimo Digesto Italiano, Torino, UTET, 1957, pág. 30. Como exemplo, o autor cita alguns excertos do Digesto, dentro os quais destacamos D. 6, 1, 20, em que se encontra a oposição entre causa rei e corpus ipsum, aduzindo-se o dever de restituição não apenas do mesmo escravo, mas também aquilo que por ventura tenha adquirido o escravo como herança ou legado, pois "não basta devolver o mesmo corpo (corpus ipsum), mas é necessário que se restitua, também, a causa da coisa (causa rei), isto é, que o demandante tenha tudo o que teria tido se, ao tempo em que aceitou o juízo tivesse sido restituído o escravo".

${ }^{242}$ Grosso, Giuseppe. Causa - diritto romano, in Enciclopedia del Diritto, Milano, Giuffrè, 1958, pág. 532. 
positivo de fazer constituir razão idônea de certo efeito jurídico, como, em particular, a aquisição do domínio (iusta causa traditionis), como em D. 41, 1, $31^{243}$.

PiETRo Bonfante apoiando-se em D. 2, 14, 7, 2; D. 19, 5, 15; e D. 15, 1, 49, 2, afirma que no direito romano, causa nada mais é que um equivalente das expressões negotium, negotium gestum, negotium proprii contractus, contractus ou, ainda, бvvó $\lambda \lambda \alpha \gamma \mu \alpha$ [sinalagma]. O autor, assim como EMILIO BETTI, também identifica nas fontes os dois sentidos objetivos de causa, especialmente como "razão" que enseja a sanção jurídica, isto é, "a essência objetiva da relação entre as partes”, o próprio negócio. Afirma o autor que, em uma infinidade de usos (iusta causa traditionis, iusta causa usucapionis), destaca-se essa relação da causa com o direito objetivo. Causae obligationum eram, para os romanos, o que nós chamamos contemporaneamente de fontes das obrigações, ou seja, as relações objetivas que são a base para o reconhecimento jurídico da obrigação ${ }^{244}$.

Formou-se grande controvérsia em torno de D. 41, 1, 31 e o problema da iusta causa traditionis por conta da conhecida antinomia entre JULIANO e ULPIANO. JULIANO, em D. 41, 1, 36, afirma que, ainda que não haja acordo a respeito da causa traditionis - se a propriedade deve ser transferida a título de doação ou mútuo -, a tradição é eficaz e transfere-se o domínio, pois os sujeitos envolvidos estão de acordo quanto ao objeto e têm a intenção de fazer passar a propriedade de uma esfera jurídica para outra ${ }^{245}$.

UlPIANO, por sua vez, em D. 12, 1, 18, pr., afirma o contrário: o desacordo a respeito da causa traditionis acarretaria a ineficácia da tradição ${ }^{246}$.

Vemos, portanto, que a despeito das inúmeras menções que se encontram nas fontes justinianéias sobre a causa, o sentido do uso da palavra não implica aquele de

${ }^{243}$ BetTI, Emilio, Causa, op. cit. (nota 241), pág. 31. Transcrevemos, a seguir, o mencionado passo do Digesto, em tradução livre: “A tradição, por si só, nunca transfere o domínio; transferirá, no entanto, se tiver sido precedida por uma venda, ou alguma justa causa em razão de que a tradição ocorre".

${ }^{244}$ Bonfante, Pietro. Il contratto e la causa del contratto, in Rivista di Diritto Commerciale, vol. VI, Parte Prima, Milano, 1908, pág. 123.

${ }^{245}$ Eis a redação de D. 41, 1, 36: "Quum in corpus quidem, quod traditur, consentiamus, in causis vero dissentiamus, non animadverto, cur inefficax sit traditio; veluti se ego credam, me ex testamento tibi obligatum esse, ut fundum tradam, tu existimes ex stipulatu tibi eum deberi; nam et si pecuniam numeratam tibi tradam donandi gratia, tu eam quase creditam accipias, constat, proprietatem ad te transire, nec impedimento esse, quod circa causam dandi atque accipiendi dissenserimus".

Há indicações de que o excerto tenha sido objeto de interpolação pela substituição da palavra mancipatio (em essência, ato abstrato), por traditio. Ver, a respeito, artigo relativamente recente de VAN VLIET, Lars P.W. Iusta causa traditionis and its history in european private law, in European Review of Private Law, $\mathrm{n}^{\circ} 3$, 2003, págs. 344-346.

${ }^{246}$ D. $12,1,18$, pr.: "Si ego quasi deponens tibi dedero, tu quasi mutuam accipias, nec depostium, nec mutuum est. Idem est, et si tu quasi mutuam pecuniam dederis, ego quasi commodatam ostendendi gratia accepi; sed in utroque casu consumtis numis condictioni sine doli exceptione locus erit". 
invalidade do contrato - bem ao contrário, como explica BONFANTE, o termo, muitas vezes, se confunde com o próprio contrato ou negócio jurídico.

A consequência para falta de causa, no Direito Romano, não está no plano da validade, mas no plano da eficácia. É o que se pode atestar por uma breve análise das actiones que eram atribuídas ao interessado se faltasse causa. Tais actiones eram as chamadas condictiones.

Havia cinco modalidades de condictiones sine causa:- condictio indebiti, condictio sine ob causam datorum, condictio ob turpem causam, condictio ob iniustam causam e condictio sine causa em sentido estrito. Todas elas aproximam-se mais das ações para repetição do que para invalidação de qualquer ato jurídico. Veja-se, por exemplo, que CORREIA TEllES, ao tratar das condictio sine causa em sua Doutrina das acções, nomeia a epígrafe ao $\$ 253$ "Acção de repetir o que outro retem sem causa, ou condictio sine causa", aduzindo, no referido parágrafo que a ação em epígrafe compete "àquelle de quem alguma cousa é retida por outro sem causa alguma: pede que este lh'a restitua com seus accessorios e rendimentos ${ }^{247}$,"

Com isso, quisemos demonstrar que as fontes justinianéias não indicam a causa como um requisito do contrato e também não revelam a formação de uma teoria da causa, cujos primeiros passos foram dados na Era Medieval ${ }^{248}$.

\subsection{2 - A causa no direito medieval.}

$\$ 1^{\mathrm{a}}$ - A causa no pensamento escolástico. Causa, para os escolásticos, "é aquilo sem o que algo não pode ser, pois todo efeito depende de uma causa que lhe corresponde". Deve-se a BOÉCIO o conhecimento que teve a escolástica da doutrina aristotélica das quatro causas - efficiens, materialis, formalis e finalis ${ }^{249}$.

\footnotetext{
${ }^{247}$ Correia Telles, José Homem. Doutrina das acções, Rio de Janeiro, Jacintho Ribeiro dos Santos, 1918, pág. 257.

${ }^{248}$ Neste sentido, LuCiAno De CAMARgo PEnTEAdo: "A teoria jurídica da causa deve seu surgimento à Jurisprudência medieval. Concebida como uma teoria, ao menos pretensamente unitária, só nessa época é que aparece. Tanto no direito contratual como no direito das condicções, ela não é de forma alguma construção do direito romano, mas sim uma generalização de regras específicas das fontes justinianéias levadas a cabo em período histórico posterior" (Doação com encargo e causa contratual, São Paulo, Dissertação (USP-FD), 2002, pág. 36.

${ }^{249}$ PENTEADO, Luciano de Camargo, op. cit. (nota 248) pág. 39.
} 
As quatro causas podem ser agrupadas em dois grupos, quais sejam, o das causas intrínsecas (material e formal) e o das causas extrínsecas (eficiente e final). A matéria sem forma é tida como mera potência, que só pode chegar a ato por meio da forma. A causa eficiente é aquela que provoca modificações. A finalidade é a guia da causa eficiente - e, nesse sentido, também o fim a ser alcançado é elemento causal, pois, "embora seja o último ponto na linha da execução da ação, é ela o primeiro momento no intuito do agente". De uma causa suficiente, segue-se apenas um efeito correspondente ${ }^{250}$.

\section{$\S 2^{\circ}$ - Apontamentos das principais contribuições medievais para a}

formação da teoria da causa. LUCIANO DE CAMARGO PENTEADO adverte que os textos medievais são imprescindíveis para o adequado entendimento a respeito da teoria da causa. No entanto, não se pode afirmar que os juristas medievais tenham chegado a elaborar, efetivamente, uma teoria, pois é evidente a ausência de uma unidade conceitual ${ }^{251}$.

Nos primeiros séculos da Idade Média, a acepção de causa revela a fluidez do conceito. Como herança do Direito Romano, permanecem em uso significados genéricos, ora para indicar justificação ou motivo, ou para indicar o suporte fático abstrato $^{252}$.

Documentos notariais desta época revelam a prática de indicar a razão de se assumir uma obrigação ou transferir um direito real. Assim, como uma forma de justificação de natureza subjetiva, individualizava-se, em uma relação de débito e crédito, o título de uma prestação. O homem medieval não esquecia de colocar em relevo nos seus documentos o conteúdo da atividade negocial, fossem as razões que o levavam até ela, fosse o objetivo que pretendia alcançar. Em ambos os casos, utilizava a narração de seus motivos pessoais que, a rigor, eram estranhos ao mundo do direito ${ }^{253}$.

Já no âmbito do Renascimento do Direito Romano, na Escola de Bolonha, os glosadores desenvolveram a doutrina dos pacta vestita que distinguia os contratos de acordo a forma com que se apresentavam. Em vista das heterogêneas fontes justinianéias,

\footnotetext{
${ }^{250}$ Idem, Ibidem, pág. 40.

${ }^{251}$ Idem, Ibidem, loc. cit.

${ }^{252}$ CORTESE, Ennio. Causa - diritto intermedio, in Enciclopedia del Diritto Milano, Giuffrè, 1958, pág. 535.

${ }^{253}$ Idem, Ibidem, pág. 536.
} 
pareceu aos medievias que a teoria do vestimento teria a vantagem de dar aspecto sistemático à matéria ${ }^{254}$.

Destaca-se a precisão dada pelos glosadores à causa impulsiva, distinguindo-a da causa final. Conforme LuCiano De CAmargo Penteado, "a causa impulsiva é o motivo, com consequências jurídicas, como possibilidade de ineficácia do ato em matéria de liberalidades quando se verificasse sua ausência”. Ainda que fosse ilícito o motivo, não haveria invalidade do acordo. Poderia, no entanto, acarretar a ineficácia perante terceiros: "por ser uma causa externa, mordente do ato e não a causa no sentido de causa fonte, seu vício não afeta a atribuição em si $^{255 ",}$.

No entanto, no mesmo período, o conceito de causa começa a adentrar no terreno da ética. Embora frequentemente a causa ficasse circunscrita a questões de direito positivo, não era raro que ultrapassasse este limite para revelar questões que diziam respeito ao âmbito da consciência, dizendo respeito não apenas ao licitum mas também ao honestum. Assim, o conceito de causa passou a intervir onde quer que fosse necessária a valoração ética de uma realidade jurídica ${ }^{256}$.

\section{3 - A elaboração da teoria da causa no período Iluminista}

\section{Code Civil.}

\subsection{1 - As obras de Domat e Pothier e a adoção de sua doutrina pelo}

Antes dos séculos XVII e XVIII, não se pode falar, com rigor, que tenha existido uma teoria da causa. É a partir desse período, especialmente em função das obras de JEAN DOMAT e RoBERT JOSEPH POTHIER, que houve a sistematização do conceito no modo em que passou para diversos códigos ao redor do globo, inclusive, segundo nossa hipótese, para o Código Comercial brasileiro.

Pretende-se, a seguir, demonstrar os principais traços desta teoria, sem esgotar o tema ou debatê-lo criticamente em contraposição às demais doutrinas sobre a causa que se seguiram no curso da História do Direito. Nosso intuito é, apenas, o de

\footnotetext{
${ }^{254}$ Couto E Silva, Clóvis V. do. A obrigação como processo, São Paulo, Bushatsky, 1976, págs. 49-50.

${ }^{255}$ PenTEAdo, Luciano de Camargo, op. cit. (nota 248), pág. 41.

${ }^{256}$ CORTESE, Ennio, op. cit., pág. 537.
} 
demonstrar de que modo a doutrina adotada pelo Código Comercial de 1850 encontra suas raízes na elaboração jusracionalista sobre a causa.

\section{$\$ 1^{\circ}$ - O papel de Jean Domat. Conforme Luciano de CAMargo Penteado,} DOMAT foi o primeiro autor a sistematizar uma teoria geral da causa. O célebre autor francês teria buscado distinguir as causas de alguns agrupamentos típicos de contratos. Nos contratos sinalagmáticos consensuais, a causa seria a equivalência entre as prestações trocadas; nos contratos reais, a entrega da coisa; na doação, o animus donandi ocuparia o lugar da causa. Desse modo, no pensamento de DoMAT, a causa é o que justifica a juridicidade do acordo, uma vez que a vontade procura um objeto lícito. Portanto, ao contrário do que ocorria no Direito Romano, aqui a causa não se confunde com suporte fático que dá ensejo à incidência ${ }^{257}$.

$\$ 2^{\circ}$ - O desenvolvimento de Robert Joseph Pothier. Com base em DOMAT, POTHIER desenvolve a teoria da causa traçando-lhe as características que, grosso modo, passaram para o regramento do Código de 1804.

Aduz o autor francês que "toda obrigação deve ter uma causa honesta", distinguindo, assim como faz DOMAT, entre os contratos "interessados" e os contratos "gratuitos", afirmando que, nos primeiros, a causa da obrigação que contrai uma das partes é que a outra parte lhe dê ou se obrigue a lhe dar, ou o risco da qual ela se encarrega; na segunda categoria, a causa é a própria liberalidade que uma das partes quer exercer ${ }^{258}$.

Assevera POTHIER que, se falta causa - ou se a causa é falsa -, o contrato é nulo e é nula a obrigação que dele resulta ${ }^{259}$.

\section{$\S^{\circ}$ - A adoção da teoria pelo Code Civil. Como já vimos (supra,} Introdução, $\S 8^{\circ}$ ), o Código Civil francês arrola a causa entre os requisitos do contrato em seu art. 1108. O art. 1131 do mesmo diploma dispõe, em seu enunciado normativo, que a

${ }^{257}$ Cfr. PenteAdo, Luciano de Camargo, op. cit. (nota 248), págs. 51-52.

${ }^{258}$ PothIER, Robert Joseph. Traité des obligations, in Oeuvres complétes de Pothier, tomo I, Paris, Chez Thomine et Fortic, 1821, pág. 41.

${ }^{259}$ Idem, Ibidem, loc. cit. 
obrigação sem causa, apoiada em falsa causa ou que tenha causa ilícita não pode ter efeito algum.

Observa-se que o Código Comercial francês de 1807 não arrola a causa entre os requisitos do contrato. Mas esse dado tem uma explicação muito simples: como na sistemática da maioria dos códigos de comércio - cosistindo notável exceção o Código brasileiro de 1850 -, o Code de Commercio não tem disposições sobre regramento geral dos contratos. Contava-se, para esse aspecto, com o subsídio do Code Civil, este sim encarregado de estabelecer o regramento geral dos contratos, enquanto o código de comércio tem a função de estabelecer as exceções pertinentes ao comércio.

\section{§4- Esclarecimento terminológico: causa enquanto requisito do contrato}

e causa do contrato. Convém, neste ponto, esclarecer que ao nos referirmos à teoria da causa como moldada por DOMAT e POTHIER e adotada no regramento do direito contratual no Code Civil, estamos tratando da causa enquanto requisito do contrato e não da doutrina que, mais tarde, situa a causa no contrato, e não em cada obrigação.

A doutrina que passou para o Code Civil - e, posteriormente, para o Código Comercial brasileiro de 1850 - é aquela da causa da obrigação, entendida enquanto a finalidade que induz cada um dos sujeitos envolvidos a contrair o vínculo. Por centrar-se na finalidade de cada contraente, esta doutrina é conhecida como subjetiva ${ }^{260}$.

A causa do contrato, por sua vez, por se referir à função econômico-social que se atribui ao contrato pelo ordenamento, sob a premissa de que nem todas as finalidades perseguidas pelos sujeitos devem ter tutela jurídica, é conhecida como doutrina objetiva sobre a causa ${ }^{261}$.

\section{$\$ 5^{\circ}$ - Principais características da teoria subjetiva da causa. GINO GORLA} esclarece que o termo causa é utilizado, frequentemente, de forma promíscua para tratar de problemas de naturezas diversas. Entre eles, interessa, particularmente, aquele da nãorealização da finalidade ou, em sentido genérico, da motivação por que é realizada uma

${ }^{260}$ Cfr. Giongianni, Michelle. Causa - diritto privato, in Enciclopedia del Diritto, Milano, Giufrè, 1958, pág. 548.

${ }^{261}$ Sobre a teoria objetiva (causa função), ver GIORGIANNI, Michelle, op. cit. (nota 260), págs. 561-564; CASTRo, Torquato. Da causa no contrato, Recife, Imprensa Universitária, 1966; e, sobretudo, BETTI, Emilio, Teoria geral do negócio jurídico (trad. port. Fernando Miranda), Coimbra, Coimbra Editora, 1969. 
atribuição patrimonial. Quem promete ou aliena o faz por uma finalidade que é separada da vontade de prometer ou alienar ${ }^{262}$.

Não é qualquer intento do sujeito que pode ser tido como causa. $\mathrm{O}$ agente pode ter vários fins ordenados para a um resultado. Quando se fala em causa, entretanto, não se fala de qualquer razão psicológica, mas daquele "fim que informa o ato, que dá a sua individualidade", e deve ser procurada dentro do ato em si, como a finalidade central que conduziu e subordinou a atividade do agente ${ }^{263}$.

Essa doutrina investiga a causa na atividade de cada contratante isoladamente, e não no contrato, como negócio que se forma pelo encontro das vontades isoladas. A causa é procurada na obrigação de cada parte, de sorte que o contrato comporta tantas causas quantas forem as obrigações de que lhe resultam ${ }^{264}$.

Assim, para GINO GoRLA, antes de tudo, a causa refere-se à atribuição patrimonial: "é neste sentido, e provavelmente apenas neste sentido, que se deve entender a “cause fausse” ou inexistante (obligation sans cause) nos artigos 1131 do Código Civil francês, 1119 do Código Civil italiano de 1865 e similares artigos dos códigos latinos ${ }^{265, "}$.

Pode-se perguntar: o que pretende o sujeito ao prometer ou atribuir? Se a respostar for que o sujeito pretende adimplir uma dívida, tem-se a causa solvendi; caso o sujeito pretenda adquirir um bem ou ver-lhe atribuído um direito, por meio de sua promessa ou alienação de um bem seu, tem-se a causa credendi (ou melhor, adquirendi); caso o intuito seja a liberalidade, tem-se, em sentido lato, causa donandi.

Caso uma atribuição solvendi causa ou adquirendi causa seja realizada e não subsiste a obrigação de adimplir, a aquisição não se realiza e a atribuição patrimonial é inválida, pois, caso a atribuição fosse mantida, ainda que não existisse a obrigação precedente ou não fosse realizado o intento de adquirir, ter-se-ia um enriquecimento, ou a conversão do ato em uma doação, o que estaria contra a finalidade ou causa que o promitente ou alienante teve em vista ${ }^{266}$.

\footnotetext{
${ }^{262}$ GoRla, Gino. Il contratto, vol. I, Milano, Giufrè, 1954, pág. 266.

${ }^{263}$ CASTRO, Torquato, op. cit. (nota 261), pág. 13.

${ }^{264}$ Idem, Ibidem, pág. 15.

265 Gorla, Gino, op. cit. (nota 262), pág. 267.

${ }^{266}$ Idem, Ibidem, págs. 268-269.
} 


\section{4 - O tratamento dispensado à causa pelo Direito Comercial brasileiro}

Trabalhamos com a hipótese de que o caminho trilhado pelo Direito Comercial brasileiro - resumidamente, a abertura empreendida pelas reformas pombalinas para a aplicação da doutrina e legislação estrangeira, a ascensão de uma elite de negociantes com interesses diversos daqueles da elite tradicionalista dos proprietários de terra, bem como o surgimento de um aparato burocrático capaz de fazer essa nova elite demandar e ver atendidos os seus pleitos - o levou a adotar, por meio de sua codificação, elementos que não necessariamente se coadunam com a tradição do direito privado lusobrasileiro.

Concretamente, um desses elementos seria, justamente, a teoria subjetiva da causa, nos moldes a que brevemente acenamos no item acima (supra, 3.3). Passamos, a seguir, a verificar de que modo se coaduna o tratamento dado à causa pelo Código de 1850 com a doutrina subjetiva de índole jusracionalista.

\subsection{1 - A causa na doutrina comercialista dos principais autores em} língua portuguesa.

§1- O Dicionário Jurídico-Comercial de José Ferreira Borges. Ao ser incumbido da tarefa de elaborar um projeto de Código Comercial para Portugal, José FERREIRA BORGES notara que faltavam textos a respeito da matéria em sua língua, de sorte que a confecção de um dicionário tornava-se imprescindível enquanto trabalho preliminar ao da codificação ${ }^{267}$.

\footnotetext{
${ }^{267}$ Eis as palavras do autor: "A necessidade de uma obra d'esta natureza entre nós é da primeira evidencia: e a falta absoluta de escriptos commerciaes entre nós exige, que ella seja formada de maneira, que possa servir ao caixeiro, ao feitor, ao guarda-livros, ao mercador de retalho e de atacado, ao negociante, aos árbitros, ao advogado, aos jurados, ao juiz inferior e aos mais altos magistrados do foro portuguez; e se é verdadeira a maxima de Johnson no prefacio a Rolt - there is no man who is not in some degree a merchant - isto é; não ha ninguem que não seja mais ou menos commerciante; - este Diccionario deve ser util a todo o portuguez e brasileiro, seja qual fôr a sua profissão ou emprego". (FERREIRA BORGES, José. Dicionário jurídicocommercial, $2^{\mathrm{a}}$ ed., Porto, Typographia de Sebastião José Pereira, 1856, pág. VI)
} 
A intenção do autor era suprir, na medida em que fosse possível, a carência de doutrina, constituindo o Dicionário um "manual a todas as classes" e obra remissiva a quem quisesse estudar a fundo o Direito Mercantil ${ }^{268}$.

O autor declarava, ainda, que sua obra seria o resultado dos seus estudos não só do Direito Comercial, mas também do Direito Civil, já que "mal poderiamos collocar a exceição se não soubessemos estabelecer a regra ${ }^{269 "}$ "

Como subsídio para as matérias de Direito Civil, utilizou FERREIRA BorgeS as disposições do Código Civil francês, "a mais sabia e precisa collecção de direito civil, que conhecemos, e que podia ser com pouquissimas exceições o Codigo geral das nações $^{270 "}$.

Talvez por buscar auxílio na legislação civil da França, o autor tenha inserido o verbete causa em sua obra ${ }^{271}$. O dicionarista afirma que causa é

"cousa que é princípio, fundamento de outra. Emprega-se esta palavra em direito para expressar o que faz objecto d'uma obrigação. Para que a obrigação seja válida a causa deve sempre ser licita. A obrigação sem causa, ou sobre falsa causa, ou sobre causa illicita não póde produzir effeito algum ${ }^{272, \text {, }}$

Fica evidente, na redação do verbete, a inspiração no art. 1131 do Code Civil, segundo o qual a obrigação sem causa, ou sobre falsa causa, ou sobre causa ilícita, não pode ter efeito algum ${ }^{273}$.

Prossegue o autor:

"É illicita a causa quando é prohibida pela lei, quando é contraria aos bons costumes, ou á ordem publica $(\ldots)^{274,}$.

\footnotetext{
${ }^{268}$ Idem, Ibidem, loc. cit.

${ }^{269}$ Idem, Ibidem, pág V.

${ }^{270}$ Idem, Ibidem, pág. VII.

${ }^{271}$ Curiosamente, embora declare no prefácio ser a obra de AZUNI (Dizionario universale ragionato della giurisprudenza mercantile, $5^{a}$ ed., Sassari, Luigi Azzati, 1844), cuja primeira edição é de 1786, uma das poucas do mesmo gênero e uma das fontes de seu trabalho, é de se notar que o italiano não inseriu em seu dicionário qualquer explicação sobre a teoria da causa. Este dado talvez corrobore ainda mais a inspiração que teve FERREIRA BORGES na doutrina e legislação francesa para esta questão específica.

${ }^{272}$ FERREIRA BORGES, op cit. (nota 267), pág. 74.

${ }^{273}$ Está assim redigido o referido artigo no original: "L'obligation sans cause, ou sur une fausse cause, ou sur une cause illicite, ne peut avoir aucun effet".
} 
Neste ponto, a correspondência é com o artigo 1133 do Código francês: a causa é ilícita quando ela é proibida pela lei, quando ela é contrária aos bons costumes ou à ordem pública $^{275}$.

Vemos, assim, que a obra de FERREIRA BORGES, importante para a formação do Direito Comercial português e também do brasileiro, já trazia consigo a influência do Code Civil no que se refere ao tratamento da causa.

\section{$\$ 2^{\circ}$ - O tratado quinto dos Princípios de Direito Mercantil de José da Silva}

Lisboa. É neste tratado, inserto nos Princípios de Direito Mercantil que JOSÉ DA SILVA LISBOA trata dos contratos mercantis.

Sobre a importância da obra para a formação do Direito Comercial brasileiro já acenamos acima (supra, 2.1.3, §3º).

O autor, no capítulo II do referido tratado, em que discorre sobre as regras gerais dos contratos, já aludia aos requisitos de validade dos contratos comerciais de forma muito semelhantes àquela consagrada no Código Comercial de 1850: que:

"O essenciaes requisitos dos Contractos mercantis, para serem validos, consistem em

1. ${ }^{\circ}$ Os Contrahentes sejão pessôas natural e civilmente capazes de contractar e dispôr do que lhes pertence.

2. ${ }^{\circ}$ Procedão de boa fé.

3. ${ }^{\circ}$ Haja mutuo assenso ou aceite.

4. ${ }^{\circ}$ Não errem no objecto do ajuste.

5. ${ }^{\circ}$ Não se opponha este ao Direito Natural, ao das gentes ou do Paiz.

6. ${ }^{\circ}$ Haja titulo real ou causa legitima que o obrigue á prestação

7. ${ }^{\circ}$ Não haja simulação em prejuizo do Estado e dos particulares que tenhão direito antecipado.

8..$^{\circ}$ não falte alguma das partes ás condições do ajuste. $9^{\circ}$ Não haja lesão enorme, e

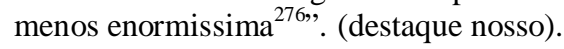

Mais adiante, o célebre comercialista brasileiro explica:

\footnotetext{
${ }^{274}$ FerReIRA Borges, op cit. (nota 267), pág. 74.

275 "Le cause est illicite, quand elle est prohibée par la loi, quand elle est contraire aux bonnes moeurs ou à l'ordre public".

${ }^{276}$ Silva Lisboa, José da. Princípios, op. cit. (nota 216), pág. 470.
} 
"Por falta do $6^{\circ}$ requisito, são nullos os Contratos, em que não haja causa de dever, isto he, quando se não mostra donde procede o titulo, e motivo justo, e possivel, porque a parte se obrigou (e não desonesto, e impossivel, visto que dahi não póde resultar obrigação), pois então suppoe-se má fé, e animo de lesar a outra parte, ou a terceiro; não se presumindo doação nos negocios da vida sem facto, e declaração especifica, e muito menos nos negocios mercantis; e não sendo justo que ninguem se locuplete com jactura alheira.

Por isso em todas as obrigações, de escripto público, se costuma, e se deve declarar o principio, donde procede a divida, se de emprestimo, se de compra e venda: se de salarios devidos, ou de outra origem, a que a Lei natural e civil assista e dê validade ${ }^{277, "}$.

Temos, portanto, que a causa enquanto requisito do contrato já estava arrolada em uma das principais obras de formação do Direito Comercial brasileiro, cuja primeira edição fora publicada entre 1798 e 1804.

Desse modo, seria mesmo possível sugerir que a invalidade do negócio por falta de causa tenha sido transplantada para o direito comercial brasileiro por meio da obra de JosÉ DA SILVA LISBOA, sendo a norma reproduzida, posteriormente, no Código Comercial.

\subsection{2 - A causa no Código Comercial de 1850.}

\$1 ${ }^{\circ}$ - O tratamento legislativo. Desde a primeira versão do projeto de Código apresentado pela comissão extraparlamentar em 1834, já se encontrava a causa como requisito de validade no regramento dos contratos mercantis. Na medida em que se apresentaram emendas, projetos substitutivos, relatórios, e etc., a norma recebeu diferentes redações e foi descolacada em relação à sua posição sistemática original. No entanto, em nenhum momento foi suprimida até ter sua redação definitiva no art. 129 , inciso $3^{278}$.

\footnotetext{
${ }^{277}$ Idem, Ibidem, loc. cit.

${ }^{278}$ No projeto apresentado em 1834, os requisitos do contrato mercantil estavam arrolados no art. 152, cuja redação era a seguinte: "São nullos os contractos commerciaes: 1. Que forem celebrados com pessoa inhabeis por contractar; 2. Os que forem contrahidos por commerciante que vier a fallir em dias anteriores á data do contracto nos termos do art. 1168; 3. Recahindo sobre objectos prohibidos pela leia, ou cujo uso e fim fôr manifestamente offensivo da sãa moral e dos bons costumes; 4. Os que forem convencidos evidentemente de fraude, dolo, simulação, ou erro; 5. Todos os que não designarem a causa de que deriva a obrigação". A redação final do artigo, como promulgada em 1850, está transcrita acima (introdução, $\S 8^{\circ}$ ).
} 
§2- Alguns apontamentos doutrinários. Mesmo em obras que não tratavam, especificamente, do Direito Comercial, Augusto TeIXEIRA DE FreITAS contribuiu para o entendimento da teoria no Brasil.

No comentário ao art. 419 de sua Consolidação das Leis Civis, TEIXEIRA DE FREITAS conceitua causa como "a razão, - o motivo, do acto ou contracto, que nos gratuitos ou beneficos é o sentimento de bem fazêr; e nos onerosos ou lucrativos é o que se-recebe pelo que se-dá ${ }^{279,}$.

De forma semelhante, o autor aduz no Vocabulário Jurídico: "causa, que se deve entender jurídica, é o motivo, abstratamente considerado, pelo qual adquirem-se direitos; (...). A causa jurídica dos atos produz seus efeitos, ou se refere a eles no total, ou em algum de seus elementos"280.

Alguns autores comercialistas brasileiros procuraram explicar o conteúdo normativo do art. 129, inc. 3 do Código Comercial de 1850.

BENTO DE FARIA, por exemplo, aduz que "a causa é o resultado jurídico, directo, o effeito immediato e essencial que as partes tiveram em vista ao contractar - o que determinou a vontade de e obrigar $(. . .)^{281}$ ”.

Prossegue o mesmo autor afirmando que a prestação ou a promessa de uma coisa ou serviço feita pela contraparte exerce a função de causa para cada um dos contratantes nos contratos a título oneroso; nos contratos remuneratórios, a causa é o serviço que se recompensa; nos contratos de "pura beneficência", a liberalidade é que serve de causa. BENTO DE FARIA aduz, ainda, seguindo Mourlon, que "só um louco poderia obrigar-se sem propôr o fim a que pretendesse attingir ${ }^{282 \%}$.

Propõe o autor brasileiro, com base em BAUDRY-LACANTINERIE, uma tentativa de diferenciar o objeto da obrigação de sua causa por meio de uma regra prática: a identificação do objeto se daria pela resposta à pergunta quid debitur? [o que se deve?]; a causa seria identificada pela resposta à pergunta cur debetur? [por que razão se deve?]

\footnotetext{
${ }^{279}$ TeIXEIRA DE Freitas, Augusto. Consolidação, op. cit. (nota 20), vol. I, pág 298.

${ }^{280}$ TEIXEIRA DE FreitAs, Augusto. Vocabulário jurídico, tomo 1, ed. comemorativa do centenário da morte do autor, São Paulo, Saraiva, 1983, págs. 26-27.

281 Bento DE FARIA, Antonio. Codigo commercial brazileiro, $2^{\mathrm{a}}$ ed., Rio de Janeiro, Jacintho Ribeiro dos Santos, 1912, pág. 112.

${ }^{282}$ Idem, Ibidem, loc. cit.
} 
O comercialista procura, ainda, distinguir causa de motivo. Afirma que causa seria o fim imediato, o elemento intencional inerente ao contrato. Motivo (a que BENTO DE FARIA chama de causa psicológica), por outro lado, seria essencialmente contingente, conforme as necessidades do contratante ${ }^{283}$.

O autor, por fim, ainda dá notícia das críticas feitas pela doutrina anticausalista, inaugurada por PLANIOL ${ }^{284}$.

O texto de BENTO DE FARIA em comentário ao art. 129, inciso 3 do Código Comercial evidencia clara influência francesa, seja pelo seu conteúdo, que em muito coincide com o pensamento de POTHIER, transposto para o Code Civil, como também pelos autores citados. Além dos já mencionados MOURLON e BAUDRY-LACANTINERIE, encontrase, também, menção a Hudelot et MetMan, Laurent Oudot, entre outros.

Com o passar dos anos, a disposição do art. 129, inciso 3 do Código Comercial passa a receber a crítica da doutrina comercialista. INGLÊS DE SOUZA, por exemplo, afirmava o seguinte:

“Antes de tudo, convém advertir que a redação do art. 129, n.3, do Código Comercial, está muito em atrazo em relação ao progresso do Direito Mercantil: é uma verdadeira velharia, visto como os contratos, em geral, são obrigatórios, ainda que não tenham uma causa aparente e, portanto, ainda que não designem uma causa certa ${ }^{285}$ ".

Argumenta o autor que seria contraproducente se todos os contratos mercantis tivessem que ter a causa analisada, pois isso afetaria a celeridade das relações comerciais. Pouco importaria, para efeito do art. 129, inciso 3, que a causa fosse real ou simulada. Afirma o autor que, muitas vezes, para manter segredo, declara-se uma causa falsa e, desde que não houvesse prejuízo para terceiros, não haveria nulidade ${ }^{286}$.

Entretanto, notícia o comercialista: "juízes e advogados ha, que se apagam ao n. 3 do art. 129, e o aplicam a rigor, declarando nulos os contratos que não tenham

\footnotetext{
${ }^{283}$ BENTO DE FARIA, Antonio, op. cit. (nota 281), págs. 112-113.

${ }^{284}$ Idem, Ibidem, pág. 113.

${ }^{285}$ InglÊs DE SoUZA, Herculano Marcos. Preleções de direito comercial, $5^{\mathrm{a}}$ ed., Rio de Janeiro, Jacyntho, 1935, pág. 153.

${ }^{286}$ Idem, Ibidem, págs. 153-154.
} 
causa ou a tenham simulada ${ }^{287, "}$. Para o autor, uma correta interpretação da disposição levaria ao entendimento contrário, pois a exigência era de indicação da causa certa de que deriva a obrigação, o que não implicaria causa verdadeira. Ou seja, a causa não precisaria ser verdadeira, bastando que fosse determinada ${ }^{288}$.

J.X. Carvalho de Mendonça nega, em seu Tratado de Direito Comercial, que seja a causa requisito do contrato mercantil. Argumenta o autor que causa do contrato é expressão que, a rigor, nada significa, e que o artigo 129, inc.3 nunca teve aplicação prática na jurisprudência, tamanha a confusão em torno do significado do seu conteúdo normativo $^{289}$.

\$3 - Exemplos de aplicação jurisprudencial do art. 129, inc. 3. Em suas anotações ao Codigo Comercial, SAlustiano Orlando DE ARAujo Costa aponta um julgado da Corte de Apelação de 04 de setembro de 1899, em que se decidia que, "para o effeito da nullidade, não tem causa certa o contracto passado com falsa causa, isto é, com uma causa que não confirma a certeza ou verdade do que foi ajustado ${ }^{290,}$.

BENTO DE FARIA noticia um acórdão do Tribunal de Justiça do Estado de São Paulo, de 17 de agosto de 1904 em que se julgou nula por falta de causa uma letra de câmbio que representava o pagamento de uma venda nula por falta de objeto ${ }^{291}$.

Na mesma obra, indica-se também acórdão do Tribunal de Justiça do Estado de São Paulo em que foi declarado nulo o contrato por falsa causa e que esta se dá quando ela é apenas aparente e não exprime a verdade do que foi ajustado ${ }^{292}$.

Assim, vemos que, a despeito das críticas de INGLÊS DE SOUZA e J.X. CARvalho DE MendonçA, tendentes a sugerir a inaplicabilidade do art. 129, inc. 3 nos tribunais brasileiros, o enunciado normativo encontrou guarida entre nós e teve, realmente, efetividade, como demonstram os exemplos acima.

\footnotetext{
${ }^{287}$ INGLÊS DE SOUZA, Herculano Marcos, op. cit. (nota 286), pág. 154.

${ }^{288}$ Idem, Ibidem, loc. cit.

${ }^{289}$ CARVALHO DE MENDONÇA, José Xavier, op. cit. (nota 21), pág. 49-50.

290 Araujo Costa, Salustiano Orlando de. Codigo commecial do Brasil, tomo I, $6^{\mathrm{a}}$ ed., Rio de Janeiro, Francisco Alves, 1909, pág. 165.

${ }^{291}$ BENTO DE FARIA, Antonio, op. cit. (nota 281), pág. 113.

${ }^{292}$ Idem, Ibidem, loc. cit.
} 


\section{Conclusão}

Procuramos, ao longo do presente estudo, percorrer o itinerário do Direito Comercial brasileiro desde suas raízes portuguesas, com as reformas pombalinas, notadamente a Lei de 18 de agosto de 1769, conhecida como a Lei da Boa Razão, e dos Novos Estatutos da Universidade de Coimbra de 1772, até chegarmos ao Código Comercial de 1850.

Partimos da premissa de que, diferentemente do Direito Civil nacional, o Direito Comercial tomou um rumo menos conservador, isto é, menos apegado à tradição jurídica luso-brasileira.

A partir deste dado constatado pela própria historiografia jurídica lusobrasileira (v. supra introdução, $\S 5^{\circ}$ ), tentamos identificar os pontos em que a evolução do Direito Comercial diferenciou-se daquela do Direito Civil no Brasil.

O primeiro ponto em que se pode verificar uma diferenciação é encontrado, justamente, no $\S 9^{\circ}$ da Lei de 18 de agosto de 1769, complementada pelo $\S 16$ dos Estatutos da Universidade de Coimbra de 1772. Impõe-se, por meio dessas disposições, como direito subsidiário ao direito nacional português - e também brasileiro -, no tocante às questões mercantis, a boa razão conforme aferida nas leis promulgadas pelas nações cultas e polidas da Europa. Abandona-se, portanto, em relação ao Direito Comercial, o Direito Romano.

O segundo ponto de diferenciação é o fim do pacto colonial e o consequente aumento das relações mercantis em território brasileiro a partir da abertura dos portos em 1808. Na medida em que praticamente não havia regulamento específico para o comércio, os tribunais luso-brasileiros - especialmente, no nosso caso, a Real Junta de Commercio, Agricultura, Fábricas e Navegação, criada em 1808 - tiveram que enfrentar uma crescente demanda por julgamentos e consultas sem ter legislação nacional de apoio. Com base nos permissos legais citados no parágrafo acima, buscou-se nas legislações estrangeiras especialmente, nos Códigos Comerciais da frança, Espanha e Portugal - o regulamento mercantil aplicável no Brasil.

Esses diplomas, que basearam os julgamentos dos casos de Direito Comercial no império luso-brasileiro e continuaram a exercer tal função após a independência, carregavam uma série de teorias e doutrinas que não necessariamente se 
coadunavam com a tradição privatista luso-brasileira e que foram, a partir de tais códigos, transplantados para o Direito Mercantil brasileiro.

No entanto, essa diferenciação quanto às fontes - as Ordenações Filipinas para o Direito Civil, e os códigos estrangeiros para o Direito Comercial - não seria suficiente para explicar os modos diversos por que se deram as codificações nacionais de ambos os ramos do Direito Privado, se não atentássemos para o substrato social que subjaz à aplicação das referidas fontes.

Com efeito, especialmente após a abertura dos portos, assiste-se no Brasil a ascenção de uma nova elite - os homens de negócio - que, por terem domínio sobre a circulação de capital conseguem controlar as atividades de intermediação, concessão de crédito, importação e exportação de bens.

Além disso, a classe mercante tinha possibilidade de fazer seus reclamos chegarem à Coroa por dois canais. O primeiro deles, pelo próprio financiamento do governo, que tomava empréstimos dos comerciantes; o segundo, era a Real Junta de Comércio, que podia fazer com que chegassem ao próprio seio da decisão política os membros da classe negociante.

Estes aspectos fizeram chegar ao Código Comercial brasileiro inovações do período jusracionalista - fato que ocorreu em medida sensivelmente menor em relação ao Direito Civil.

Procuramos demonstrar que a causa em sentido subjetivo, como cunhada por JEAN DOMAT e ROBERT JOSEPH POTHIER e, posteriormente, adotada pelo Code Civil de 1804, foi inserta também no Código Comercial brasileiro de 1850. A inserção da causa subjetiva como requisito do contrato mercantil prova, por sua vez, a influência do pensamento jusracionalista no Direito Privado brasileiro.

Deve-se notar que a adoção desta teoria não é um dado meramente incidental. Pelo contrário, o art. 129 do Código Comercial foi, ao longo de sua vigência, um enunciado normativo central no sistema de Direito Privado brasileiro, apresentando repercussões em vários âmbitos.

Chega a causar espanto constatar que durante mais de um século tenhamos tido entre nós regramentos diversos, com raízes em tradições jurídicas diversas, dentro do Direito Privado. 
Em conclusão, esperamos ter demonstrado que o Direito Privado brasileiro, embora ainda hoje muito mais próximo da tradição lusitana do que o próprio Direito Privado português, não passou tão incólume às inovações Iluministas. Houve quem afirmasse que o Código Comercial brasileiro não tenha sofrido qualquer influência de seu congênere francês ${ }^{293}$, o que parece ser fruto de alguma negligência da historiografia jurídica nacional em relação às raízes de um de nossos principais monumentos jurídicos o Código Comercial de 1850.

${ }^{293}$ AZEVEDo, Antônio Junqueira de. Influência do direito francês sobre o direito brasileiro, in Revista da Faculdade de Direito da Universidade de São Paulo, no 89, 1994, pág. 190. 


\section{Obras Consultadas}

ANDRADE, Antonio Alberto de. Vernei e a cultura de seu tempo, Coimbra, Acta Universitatis Coninbrigensis, 1966.

Araujo Costa, Salustiano Orlando de. Codigo commecial do Brasil, tomo I, $6^{\mathrm{a}}$ ed., Rio de Janeiro, Francisco Alves, 1909

ARóSTEGUI, Júlio. La investigación histórica: teoria y método, Barcelona, Critica, 1995 (trad. port. Andréa Dore, A pesquisa histórica: teoria e método, Bauru, Edusc, 2006).

ARRUDA, José Jobson de Andrade. Uma colônia entre dois impérios: a abertura dos portos brasileiros (1800-1808), Bauru, EDUSC, 2008.

AZEVEDo, Antônio Junqueira de. Negócio jurídico - existência, valide e eficácia, $4^{\mathrm{a}}$ ed., São Paulo, Saraiva, 2002.

AZUNI, Alberto. Dizionario universale ragionato della giurisprudenza mercantile, $5^{\mathrm{a}}$ ed., Sassari, Luigi Azzati, 1844.

Bento DE FARIA, Antonio. Codigo commercial brazileiro, $2^{\mathrm{a}}$ ed., Rio de Janeiro, Jacintho Ribeiro dos Santos, 1912.

BETTI, Emilio. Causa - diritto romano, in Novissimo Digesto Italiano, Torino, UTET, 1957.

Teoria geral do negócio jurídico (trad. port. Fernando Miranda), $1^{\mathrm{a}}$ ed., Coimbra, Coimbra Editora, 1969.

. Teoria generalle delle obbligazioni, $1^{\text {a }}$ ed., Milano, Giuffrè, 1953.

BONFANTE, Pietro. Il contratto e la causa del contratto, in Rivista di Diritto commerciale, vol. VI, Parte Prima, Milano, 1908.

BRAGA DA CRUZ, Guilherme. A formação histórica do moderno direito privado português e brasileiro, in Revista da Faculdade de Direito da Universidade de São Paulo, vol. 50, 1955.

O direito subsidiário na história do direito português, in Obras esparsas, vol. II, $2^{\mathrm{a}}$ parte, Coimbra, Acta Universitatis Conimbrigensis, 1981.

BRETONE, Mario. Storia del diritto romano, Bari, Laterza, 1987 (trad. port. Isabel Teresa Santos e Hossein Seddighzadeh Shooja, História do direito romano, Lisboa, Estampa, 1998). 
BURKe, Peter. A nova história, seu passado e seu futuro, in BURKE, Peter (org.) New perspectives on historical writing, Oxford, Blackwell, 1991 (trad. port. Magda Lopes. A escrita da história: novas perspectivas, São Paulo, UNESP, 1992).

CABral de Moncada, Luís. Um iluminista português do século XVIII: Luís António Verney, São Paulo, Saraiva, 1941

CAENEGEM, Raoul Charles van. Introduction historique au droit prive, Bruxelles, StoryScentia, 1988 (trad. port. Carlos Eduardo Lima Machado. Uma introdução histórica ao direito privado, $2^{a}$ ed., São Paulo, Martins Fontes, 2000).

CARdoso, José Luís. A transferência da corte a abertura dos portos:Portugal e Brasil entre a ilustração e o liberalismo econômico, in OLIVEIRA, Luís Valente de; RICUPERO, Rubens (org.). A abertura dos portos, São Paulo, Senac, 2007.

CARVAlHo DE MENDONÇA, José Xavier. Tratado de direito comercial brasileiro, vol. I, Rio de Janeiro, Freitas Bastos, 1963.

CARvalho, Joaquim de. A crítica da segunda escolástica portuguesa, introdução a LOCKE, John. Ensaio philosophico sobre o entendimento humano. Resumo dos Livros I e II, recusado pela mesa Real Censória e agora dado ao prelo com introdução e apêndice, Coimbra, Biblioteca da Universidade, 1950 (agora in $O$ nascimento da moderna pedagogia: Verney, Rio de Janeiro, Documentário/PUC-Rio, 1979).

Correia Telles, José Homem. Commentario critico á Lei da Boa Razão em data de 18 de agosto de 1769, Lisboa, Antonio José de Barros e Sá, 1824

Digesto portuguez ou tratado dos direitos e obrigações civis accomodado ás leis e costumes da nação portugueza para servir de subsidio ao novo codigo civil, tomo I, Coimbra, Imprensa da Universidade, 1835.

Santos, 1918.

. Doutrina das acções, Rio de Janeiro, Jacintho Ribeiro dos

Cortese, Ennio. Causa - diritto intermedio, in Enciclopedia del Diritto, Milano, Giuffrè, 1958.

Couto E Silva, Clóvis V. do. A obrigação como processo, $1^{\circ}$ ed., São Paulo, José Bushatsky, 1976.

. $O$ direito civil brasileiro em perspectiva história e visão de futuro, in Revista dos Tribunais, $\mathrm{n}^{\circ}$ 628, 1988 (agora in FRADERA, Vera Maria Jacob. $O$ direito privado brasileiro na visão de Clóvis do Couto e Silva, Porto Alegre, Livraria do Advogado, 1997).

Teoria da causa no direito privado, in Revista Jurídica, $\mathrm{n}^{\circ} 8$, Porto Alegre, Ed. Sulina, 1954 (agora in FRADERA, Vera Maria Jacob (org.). O direito privado brasileiro na visão de Clóvis do Couto e Silva, $1^{\mathrm{a}}$ ed., Porto Alegre, Livraria do Advogado Editora, 1997). 
DelamarRe, M.; Le PoITVIn, M. Traité théorique et pratique de droit commercial, tomo I, Paris, Charles Hingray, 1861.

FELÍcio DOS SANTOS, Joaquim. Projecto de codigo civil brasileiro e commentario, 5 tomos, Rio de Janeiro, H. Lammert, 1884.

Ferreira Borges, José. Diccionario jurídico-commercial, $2^{a}$ ed., Porto, Sebastião José Pereira, 1856.

Jurisprudencia do contracto-mercantil de sociedade, segundo a legislação, e arestos dos codigos e tribunaes das naçoens mais cultas da Europa, $2^{\mathrm{a}}$ ed., Lisboa, Sociedade Propagadora dos Conhecimentos Uteis, 1844.

FERREIRA, Breno Ferraz Leal. Contra todos os inimigos. Luís António Verney: historiografia e método crítico, Dissertação, São Paulo-USP(FFLCH), 2009.

FERREIRA, Joaquim. Luís António Verney e o Verdadeiro método de estudar, in JUNQUEIRA, Celina; PAIM, Antônio (org.). O nascimento da moderna pedagogia: Verney, Rio de Janeiro, Documentário/PUC-Rio, 1979.

FERREIRA, Waldemar Martins. Instituições de direito comercial, $3^{\mathrm{a}}$ ed., São Paulo, Freitas Bastos, 1951.

FREITAS, Caio de. George Canning e o Brasil: influência da diplomacia inglesa na formação brasileira, vol. I, São Paulo, Cia. Editora Nacional, 1958.

Forgioni, Paula Andrea. A evolução do direito comercial brasileiro: da mercancia ao mercado, São Paulo, RT, 2009.

GARnSEY, Peter; SAller, Richard. The Roman empire: economy, society and culture, London, Duckworth, 1987.

Giorgianni, Michelle. Causa - diritto privato in Enciclopedia del Diritto, Milano, Giuffrè, 1958.

GOMES, Laurentino. 1808: como uma rainha louca, um príncipe medroso e e uma corte corrupta enganaram Napoleão e mudaram a história de Portugal e do Brasil, $2^{a}$ ed., São Paulo, Planeta, 2007.

GoMES, Orlando. Raízes históricas e sociológicas do código civil brasileiro, $1^{\mathrm{a}}$ ed., São Paulo, Martins Fontes, 2003.

Gomes Da SILVA, Nuno José Espinosa. História do direito português: fontes de direito, $4^{\mathrm{a}}$ ed., Lisboa, Calouste Gulbenkian, 2006.

GoRLA, Gino. Il contratto - problemi fondamentali trattati con il metodo comparativo e casistico, Milano, Giuffrè, 1954 
InglêS DE SouZA, Herculano Marcos. Preleções de direito comercial, $5^{\mathrm{a}}$ ed., Rio de Janeiro, Jacyntho, 1935.

KIRSCHNER, Tereza Cristina. José da Silva Lisboa, Visconde de Cairu: itinerários de um ilustrado luso-brasileiro, Belo Horizonte, Alameda, 2009.

LIMA LOPES, José Reinaldo. A formação do direito comercial brasileiro: a criação dos tribunais de comércio do império, in Cadernos Direito GV, vol. 4, nº 6, nov. 2007.

LOPES, Miguel Maria de Serpa. Curso de direito civil, vol I, $6^{\text {a }}$ ed., Rio de Janeiro, Freitas Bastos, 1988.

LOPES, Oscar. Verney e a crise do humanismo clássico, in Seara Nova, $\mathrm{n}^{\circ}$ especial comemorativa do $2^{\circ}$ centenário da publicação do Verdadeiro método de estudar, Lisboa, 1947 (agora in JUNQUEIRA, Celina; PAIM, Antônio (org.). O nascimento da moderna pedagogia: Verney, Rio de Janeiro, Documentário/PUC-Rio, 1979).

LOPES, Walter de Mattos. "A real Junta de commercio, agricultura, fábricas e navegação deste Estado do Brazil e seus domínios ultramarinos": um tribunal de antigo regime na corte de Dom João (1808-1821), Dissertação, Niterói-PPGH/UFF, 2009.

MANCHESTER, Alan K. British preeminence in Brazil - its rise and decline: an study in european expansion, Chapel Hill, The University of North Carolina Press, 1933.

Mello, Marcos Bernardes de. Teoria do fato jurídico - plano da existência, $14^{\mathrm{a}}$ ed., São Paulo, Saraiva, 2007.

MoreIRA Alves, José Carlos. Da alienação fiduciária em garantia, $1^{\text {a }}$ ed., São Paulo, Saraiva, 1973.

1999. Direito romano, vol. I, $12^{\mathrm{a}}$ ed., Rio de Janeiro, Forense, Panorama do direito civil brasileiro: das origens aos dias atuais, in Revista da Faculdade de Direito da Universidade de São Paulo, vol. 88, 1993.

NEVES, Edson Alvisi. Magistrados e negociantes na corte do Império do Brasil: o tribunal do comércio (1850-1875), Rio de Janeiro, Jurídica do Rio de Janeiro-FAPERJ, 2008.

Silva, Maria Beatriz Nizza. A Gazeta do Rio de Janeiro (1808-1822): cultura e sociedade, Rio de Janeiro, EdUERJ, 2007.

OliveIRA, Luís Valente de; Ricupero, Rubens (org.). A abertura dos portos, São Paulo, Senac, 2007.

OliveIRA Vianna, Francisco José. Institiuções políticas brasileiras, $2^{\mathrm{a}}$ ed., vol. I, Rio de Janeiro, José Olympio, 1955.

Penteado, Luciano de Camargo. Doação com encargo e causa contratual, Dissertação, São Paulo, 2002. 
Pimental, Diogo Pereira Forjaz de Sampaio. Annotações ao codigo de commercio portuguez, $2^{\text {a }}$ ed., 3 tomos, Coimbra, Imprensa da Universidade, 1866.

PONTES DE MiRAndA, Francisco Cavalcanti. Fontes e evolução do direito civil brasileiro, $2^{a}$ ed., São Paulo, RT, 1981.

ed., Rio de Janeiro, Borsoi, 1954.

Tratado de direito privado, tomo III, $1^{\text {a }}$

PousADA, Estevan Lo Ré. Preservação da tradição jurídica luso-brasileira: Teixeira de Freitas e a introdução à Consolidação das Leis Civis, Dissertação, São Paulo-USP(FD), 2006.

RATTON, Diogo. Reflexões sobre codigo mercantil sobre tribunaes do commercio e sobre navegação mercantil, Lisboa, 1821.

RICUPERO, Rubens. O problema da abertura dos portos, in OLIVEIRA, Luís Valente de; RICUPERO, Rubens (org.). A abertura dos portos, São Paulo, Senac, 2007.

Rocha, Antonio Penalves (org.). José da Silva Lisboa, Visconde de Caiuru, São Paulo, 34, 2001.

RusSEl, Alfredo. Curso de direito comercial, vol. I, parte 1, Rio de Janeiro, 1938.

SALGADO JÚNIOR, Antônio. Sobre a suposta parcialidade polêmica do "Verdadeiro método de estudar, in Seara Nova, $\mathrm{n}^{\circ}$ especial comemorativa do $2^{\circ}$ centenário da publicação do Verdadeiro método de estudar, Lisboa, 1947 (agora in JUNQUEIRA, Celina; PAIM, Antônio (org.). O nascimento da moderna pedagogia: Verney, Rio de Janeiro, Documentário/PUC-Rio, 1979).

SAntos, Mariana A. Machado. Verney e o bom gosto, in Seara Nova, $\mathrm{n}^{\circ}$ especial comemorativa do $2^{\circ}$ centenário da publicação do Verdadeiro método de estudar, Lisboa, 1947 (agora in JUNQUEIRA, Celina; PAIM, Antônio (org.). O nascimento da moderna pedagogia: Verney, Rio de Janeiro, Documentário/PUC-Rio, 1979).

SÉRgIO, Antônio. Luís António Verney, apóstolo cívico, in Seara Nova, $\mathrm{n}^{\circ}$ especial comemorativa do $2^{\circ}$ centenário da publicação do Verdadeiro método de estudar, Lisboa, 1947 (agora in JUNQUEIRA, Celina; PAIM, Antônio (org.). O nascimento da moderna pedagogia: Verney, Rio de Janeiro, Documentário/PUC-Rio, 1979).

SERrÃo, Joel. A latinidade, Luís António Verney e o Sr. Severiano Tavares. in Seara Nova, $\mathrm{n}^{\circ}$ especial comemorativa do $2^{\circ}$ centenário da publicação do Verdadeiro método de estudar, Lisboa, 1947 (agora in JUNQUEIRA, Celina; PAIM, Antônio (org.). O nascimento da moderna pedagogia: Verney, Rio de Janeiro, Documentário/PUC-Rio, 1979).

Silva LisBoA, José da. Observações sobre a franqueza da indústria, e estabelecimento de fábricas no Brasil, Brasília, Senado Federal, 1999. 
Princípios de direito mercantil e leis de marinha divididos em sete tratados elementares, contendo a respectiva legislação patria, e indicando as fontes originaes dos regulamentos maritimos das principaes praças da Europa, 2 tomos, $6^{\text {a }}$ ed. Rio de Janeiro, Acadêmica, 1874.

Regras da praça ou bases de regulamento commercial conforme aos novos codigos de commercio da França e Hespanha, e á legislação pátria com opportunas modificações de estatutos e usos da nações civilisadas, Rio de Janeiro, Acadêmica, 1874.

TeiXeIRA De Freitas, Augusto. Consolidação das leis civis, $3^{\mathrm{a}}$ ed., Rio de Janeiro, Garnier, 1876 (ed. fac-similar, Brasília, Senado Federal, 2003).

VARnhagen, Francisco Adolpho de. História Geral do Brazil, tomo II, Rio de Janeiro, Laemmert, 1857.

VENTURI, Franco. Utopia and reform in the Enlightenment, Cambridge, Cambridge University Press, 1971 (trad. port. FloRENZANO, Modesto, Utopia e reforma no iluminismo, Bauro, Edusc, 2003).

VERNEY, Luís António. O verdadeiro método de estudar, 2 tomos, Valensa [Nápoles], Antonio Balle [Genaro e Vincenzo Muzio], 1746.

VEIGA, Manoel Luís da. Reflexões críticas sobre a obra de José da Silva Lisboa, intitulada, Principios de Direito Mercantil: feitas por hum homem da mesma profissão, Lisboa, Antonio Rodrigues Galhardo, 1803.

VON THUR, Andreas. Der allgemeine Teil des Deutschen bürgerlichen Rechts, vol. III, parte1, Leipzig, Duncker und Humblot, 1910-18 (trad. esp. Tito Rava, Buenos Aires, Depalma, 1948).

WIEACKER, Franz. Privatrechtgechichte der neuzeit unter besonder Berücksichtigungder deutschen Entwicklung, 2a ed., Göttingen, Vandenhoeck und Ruprecht, 1967 (trad. port. Hespanha, Antônio Manoel Botelho. História do direito privado moderno, $2^{\mathrm{a}}$ ed., Lisboa, Calouste Gulbenkian, 1993). 


\section{Resumo}

Este estudo versou sobre os caminhos da formação do Direito Comercial brasileiro a partir das reformas pombalinas no século XVIII até a promulgação do Código Comercial brasileiro de 1850 , procurando expor em quais pontos em se diferenciou do Direito Civil.

Para tanto, no primeiro capítulo, expôs-se de que forma se deu a penetração das ideias Iluministas em Portugal, especialmente por meio da obra de LUís ANTÓNIO VERNEY. Em seguida, procurou-se demonstrar como essas ideias informaram as reformas levadas a efeito pelo Marquês de Pombal no século XVIII.

No segundo capítulo, objetivou-se evidenciar as alterações na sociedade e na estrutra do império luso-brasileiro a partir da abertura dos portos em 1808 e de que forma estas alterações tiveram impacto na História do Direito Comercial nacional.

O terceiro capítulo destinou-se a provar o influxo de ideias jusracionalistas no Direito Comercial brasileiro por meio da adoção da teoria subjetiva da causa, consagrada legislativamente no Código Civil francês de 1804.

O trabalho, portanto, destinou-se a por em relevo um aspecto da História do Direito privado brasileiro que não se coaduna com a tradição jurídica luso-brasileira. 


\begin{abstract}
This study refers to the formation of Brazilian Commercial Law from the pombalina's reforms until the promulgation of the Brazilian Code of Commerce in 1850. Throughout the work we tried to demonstrate how the Commercial Law followed a different tradition comparing with the Civil Law in Brazil.

Thus, the first chapter demonstrates the Enlightenment influx in Portugal, specially through the work of LUÍS ANTÓNIO VERNEY. Then, the influence of VERNEY'S ideas and the reforms that took place by the hands of the Marquês de Pombal in Portugal was showed.

The second chapter demonstrates the social and political modifications that happened in the Portuguese Empire after the opening of the Brazilian ports to the trade of the world. At this point, there was also a study on the impact of the these developments in the History of the Brazilian Commercial Law.

The third and last chapter attempts to prove the influx of Enlightenment demonstrating that the Code of Commerce of 1850 adopts the subjective theory of cause which is the same as in the French Code Civil of 1804.

Therefore, this work demonstrated how the Brazilian Commercial Law followed different juridical tradition in comparison with the Brazilian Civil Law.
\end{abstract}

